CRISIANE APARECIDA MARANGON

\title{
ATIVIDADE ANTIMICROBIANA E CITOTOXICIDADE DE EMULSÕES DE QUITOSANA/GELATINA/ÓLEO DE COPAÍBA
}

São Carlos

2015 


\section{ATIVIDADE ANTIMICROBIANA E CITOTOXICIDADE DE EMULSÕES DE QUITOSANA/GELATINA/ÓLEO DE COPAÍBA}

VERSÃO CORRIGIDA

Dissertação de mestrado apresentada ao Programa de PósGraduação Interunidades Bioengenharia - Escola de Engenharia de São Carlos / Faculdade de Medicina de Ribeirão Preto / Instituto de Química de São Carlos da Universidade de São Paulo como parte dos requisitos para obtenção do título de mestre em Ciências.

Área de concentração: Bioengenharia

Orientadora: Profa. Dra. Ana Maria de Guzzi Plepis

Co-orientadora: Profa. Dra. Márcia Nitschke

São Carlos

2015 
AUTORIZO A REPRODUCÃO TOTAL OU PARCIAL DESTE TRABALHO. POR QUALQUER MEIO CONVENCIONAL OU ELETRONICO, PARA FINS DE ESTUDO E PESQUISA, DESDE QUE CITADA A FONTE.

Ma11a

Marangon, Crisiane Aparecida

Atividade antimicrobiana e citotouicidade de emulges de quitosana/gelatina/bleo de copaiba/ Crisiane Aparecida Marangon; orientador Brofa. Ana Maria de Guzai Plepig goorientador Brota. Mareia Mitschle. BAo Carlog, 2015.

Dissertaglo (Kestrado) - Frograma de Zos-Graduaglo Interunidades Bioengenharia e Area de Concentraglo em Bioengenharia -- Escola de Engenharia de SAo Carlog; Faculdade de Kedicina de Ribeirlo Breto: Instituto de Quiniea de BSo Carlos, da Universidade de BSo Raulo, 2015.

1. Quitosana. 2. Gelatina. 2. Oleo de copafiba. 4. Atividade antimicrobiana.. I. Titulo. 
Dedico este trabalho a minha família, e ao meu companheiro, Renan Henrique dos Santos, por toda paciência, apoio, orações, carinho e ensinamentos de vida. Em especial, aos meus queridos avós, Odete Scherma Custódio e Aparecido Custódio, pelos exemplos de vida e por ser meu alicerce, dedico toda a essência que representa este trabalho a vocês. Meus amigos e amores, minha família. 


\section{Agradecimentos}

À Deus e todos os Santos por proteger, reger, fortalecer, guardar e iluminar meu caminho.

À minha família pelo incentivo, exemplos de vida, alicerce, paciência, orações, carinho e apoio em todos os momentos e de todas as formas.

Ao meu namorado Renan Henrique dos Santos pelo apoio, paciência, carinho e companheirismo.

À minha amiga Gracie Luiza da Silva pela confiança, amizade e oportunidade de realizar esse trabalho, meu profundo respeito e admiração e pelo prazer e honra da amizade da professora que me inspirou a escolher a microbiologia para atuar profissionalmente. Muito obrigada por tudo.

À minha orientadora, Profa. Dra. Ana Maria de Guzzi Plepis, exemplo de competência, postura e sucesso profissional, meu profundo respeito e admiração. Muito obrigada pela oportunidade, confiança, conhecimento científico, amizade, orientação, compreensão e incentivo durante toda a trajetória desse trabalho.

À minha co-orientadora, Profa. Dra. Márcia Nitschke, exemplo de profissional, postura e dedicação, meu profundo respeito e admiração. Obrigada pela oportunidade, portas abertas em meu caminho, confiança, ensinamentos, paciência e compreensão.

À Virginia Conceição Amaro Martins pela amizade, ajuda, preciosas sugestões, críticas, discussões científicas, apoio, carinho, paciência e compreensão. É um prazer e uma honra ser amiga de uma pesquisadora tão humana e de caráter, exemplo de profissional e de vida. Muito obrigada por tudo.

Ao meu aluno de iniciação científica e amigo Pedro Leite, por toda ajuda, apoio, dedicação e bons momentos.

Aos amigos de pós-graduação e funcionários, Marília Horn, Lívia, Max, Murilo, Eduardo, Lucas de Freitas, Mirela, Claudio, Lucas Amaral, Jorge, Marcio, Sumaria, Gabriela, Débora, Jakeline, Marília Peret e João Pedro muito obrigada pelas sugestões, críticas, discussões científicas, apoio nos experimentos, suporte 
técnico, amizade, bom humor, excelente convívio e momentos de alegria contagiante que tornaram prazeroso os dias de trabalho nos laboratórios.

À Profa. Dra. Janice Rodrigues Perussi e a técnica Dra. Cláudia Bernal, do Laboratório de Cultura Celular e Fotossensibilizadores do IQSC - USP, pelos ensaios de citotoxicidade, pela atenção e competência nos experimentos realizados.

Ao Prof. Dr. Clovis Wesley Oliveira de Souza, do Departamento de Morfologia e Patologia da UFSCar, e ao Prof. Dr. Andrei Leitão, do Departamento de Química e Física Molecular do IQSC - USP pela valiosa contribuição no exame de qualificação do mestrado.

Ao CNPq pelo apoio financeiro.

Ao Programa de Pós-Graduação Interunidades Bioengenharia EESC/FMRP/IQSC - USP.

À todos que contribuíram direta ou indiretamente para a realização deste trabalho. 
"Tenho a impressão de ter sido uma criança brincando à beira-mar, divertindo-me em descobrir uma pedrinha mais lisa ou uma concha mais bonita que as outras, enquanto o imenso oceano da verdade continua misterioso diante de meus olhos".

(Isaac Newton) 


\section{RESUMO}

MARANGON, C. M. ATIVIDADE ANTIMICROBIANA E CITOTOXICIDADE DE EMULSÕES DE QUITOSANA/GELATINA/ÓLEO DE COPAÍBA. 2015. $95 \mathrm{f}$. Dissertação (Mestrado) - Programa de Pós-Graduação Interunidades Bioengenharia - Escola de Engenharia de São Carlos - EESC / Faculdade de Medicina de Ribeirão Preto - FMRP / Instituto de Química de São Carlos - IQSC, Universidade de São Paulo, São Carlos, 2015.

A resistência bacteriana aos antibióticos tem se disseminado mais rapidamente do que a introdução de novos compostos, portanto, a investigação e desenvolvimento de novas moléculas para o controle microbiano é necessário. $O$ presente estudo teve como objetivo avaliar a atividade antimicrobiana de diferentes óleos de copaíba $\mathrm{OC}(\mathrm{S}), \mathrm{OC}(\mathrm{C})$ e $\mathrm{OC}(\mathrm{E})$, do gel de quitosana/gelatina $(\mathrm{QG})$ e de emulsões de quitosana/gelatina/óleo de copaíba (QGOC) frente às linhagens de Staphylococcus aureus ATCC 25923, Escherichia coli ATCC 25922 e Pseudomonas aeruginosa ATCC 27873. A quitosana foi obtida a partir de gládios de lula por desmineralização, desproteinização e desacetilação e uma solução a $2 \%$ foi preparada em ácido acético $1 \%$. O gel de gelatina $2 \%$ foi obtido por dissolução de gelatina comercial (Sigma) em água, sendo gelatinizada a $60{ }^{\circ} \mathrm{C}$ por $30 \mathrm{~min}$. O gel QG e as emulsões $\mathrm{QGOC}(\mathrm{S}), \mathrm{QGOC}(\mathrm{C})$ e $\mathrm{QGOC}(\mathrm{E})$ foram preparadas pela mistura dos géis de quitosana e gelatina na proporção 2:1 sob agitação constante. A concentração das emulsões QGOC foi ajustada de acordo com a concentração inibitória mínima (CIM) encontrada para o gel QG e para os óleos individualmente. Os ensaios de atividade antimicrobiana foram realizados utilizando-se a técnica de microdiluição em caldo para a determinação da CIM e da concentração bactericida mínima (CBM). O efeito citotóxico dos compostos também foi investigado sobre células VERO. Os valores de CIM e CBM para o gel QG sobre $S$. aureus, E. coli e $P$. aeruginosa foram de 31,$2 ; 62,5 \mathrm{e} 31,2 \mu \mathrm{g} \mathrm{mL}^{-1}$, respectivamente, no entanto para $P$. aeruginosa observou-se que o gel mostrou atividade bacteriostática. Os óleos de copaíba apresentaram atividade apenas para S. aureus, com CIM e CBM de 2000 $\mu \mathrm{g} \mathrm{mL}{ }^{-1}$ para $\mathrm{OC}(\mathrm{S}), 500 \mu \mathrm{g} \mathrm{mL}{ }^{-1}$ para $\mathrm{OC}(\mathrm{C})$ e $62,5 \mu \mathrm{gL}^{-1}$ para $\mathrm{OC}(\mathrm{E})$, com caráter bactericida. A interação entre os antimicrobianos na forma da emulsão $\mathrm{QGOC}(\mathrm{E})$ sugere efeito sinérgico para $S$. aureus. As demais emulsões não apresentaram efeito sinérgico, entretanto, a atividade antimicrobiana e o efeito bactericida foram mantidos com a adição dos óleos no gel QG, com exceção da bactéria $P$. aeruginosa em que a adição dos óleos reduziu a eficácia do gel QG. Os óleos de copaíba apresentaram efeito citotóxico sobre as células VERO, enquanto o gel QG e a combinação na forma de emulsões não mostraram citotoxicidade. Os resultados desse estudo evidenciam que a combinação QGOC pode ser uma fonte em potencial para o desenvolvimento de um novo agente antimicrobiano seletivo no controle de infecções bacterianas.

Palavras-chave: quitosana, gelatina, óleo de copaíba, atividade antimicrobiana. 


\section{ABSTRACT}

MARANGON, C. M. ANTIMICROBIAL AND CYTOTOXIC ACTIVITY OF CHITOSAN/GELATIN/ COPAÍBA OIL EMULSION. 2015. 95 f. Dissertação (Mestrado) - Programa de Pós-Graduação Interunidades Bioengenharia - Escola de Engenharia de São Carlos - EESC / Faculdade de Medicina de Ribeirão Preto FMRP / Instituto de Química de São Carlos - IQSC, Universidade de São Paulo, São Carlos, 2015.

Antibiotic resistance increases faster than the introduction of new compounds thus, the research and development of new drugs and antimicrobial systems is required. This study aimed to evaluate the antimicrobial activity of different copaiba oils $\mathrm{CO}(\mathrm{S}), \mathrm{CO}(\mathrm{C})$ and $\mathrm{CO}(\mathrm{E})$, chitosan/gelatin gel $(\mathrm{CG})$ and chitosan/gelatin/copaiba oil (CGCO) emulsions against the strains of Staphylococcus aureus ATCC 25923, Escherichia coli ATCC 25922 and Pseudomonas aeruginosa ATCC 27873. Chitosan was obtained from squid pens by desmineralization, desproteinization and deacetylation and a $2 \%$ solution was prepared in $1 \%$ acetic acid. A $2 \%$ gelatin gel was obtained by dissolution of commercial gelatin (Sigma) in water and gelatinized at $60 \stackrel{\circ}{\mathrm{C}}$ for $30 \mathrm{~min}$. CQ gel and CQCO emulsions were prepared by mixing chitosan and gelatin gels at 2:1 (w/w) ratio under constant stirring. The concentration of CGCO emulsions were adjusted according to the minimum inhibitory concentration (MIC) for CG gel and oils separately. MIC and minimum bactericidal concentrations (MBC) with oils, CG gel and CGCO emulsions were determined using the micro-broth dilution technique. The cytotoxicity effect of compounds on VERO cell line was also evaluated using the MTT assay. CG gel inhibited $S$. aureus, $E$. coli and $P$. aeruginosa growth showing a MIC and a MBC of $31.2 ; 62.5$ and $31.2 \mu \mathrm{gL}^{-1}$, respectively except for $P$. aeruginosa, that showed bacteriostatic effect. Copaiba oils inhibited only $S$. aureus with MIC and MBC of $2,000 \mu \mathrm{g} \mathrm{mL}^{1}$ to $\mathrm{CO}(\mathrm{S}), 500 \mu \mathrm{g} \mathrm{mL}^{1}$ to $\mathrm{CO}(\mathrm{C})$ and $62.5 \mu \mathrm{g} \mathrm{mL}{ }^{1}$ to $\mathrm{CO}(\mathrm{E})$. The combined emulsion $\mathrm{CGCO}(\mathrm{E})$ suggesting synergistic effect to $S$. aureus. However, the other emulsions showed not synergistic effect, but showed the same MIC and MBC values as those obtained for the isolated compounds, except for $P$. aeruginosa where the addition of oils reduced the effectiveness of $C Q$ gel. The copaiba oils showed toxicity to VERO cells, while the CG gel and the CGCO were not cytotoxic. The results of this study demonstrated that the combination of CGCO may be a potential source for the development of a new selective agent to control these important bacterial pathogens.

Keywords: chitosan, gelatin, copaiba oil, antimicrobial activity. 


\section{LISTA DE FIGURAS}

Figura 1 - O relógio da vida na Terra. ....................................................23

Figura 2 - A estrutura da pele humana ..................................................... 25

Figura 3 - Principais mecanismos de resistência microbiana a agentes antimicrobianos. 29

Figura 4 - Estrutura da quitosana obtida a partir da desacetilação parcial da quitina.

Figura 5 - Esquema das possíveis aplicações para a quitosana.........................33

Figura 6 - llustração do efeito antimicrobiano da quitosana. .............................34

Figura 7 - Estrutura do colágeno e da gelatina.......................................... 36

Figura 8 - Estrutura química dos principais sesquiterpenos e diterpenos com atividade antimicrobiana encontrados no óleo de copaíba....................................42

Figura 9 - Fotografia digital dos óleos de copaíba: (A) OC(S), (B) OC(C) e (C) OC(E).

Figura 10 - Fotografia digital: (A) OC(S), (B) QG e (C) QGOC(S) .....................48

Figura 11 - Esquema representativo do procedimento experimental para os testes de atividade antimicrobiana.

Figura 12 - Princípio da reação de redução do sal de MTT pela desidrogenase mitocondrial das células viáveis. 60

Figura 13 - Quitosana obtida no processo de desacetilação da $\beta$-quitina. 62

Figura 14 - Curva de titulação condutimétrica da quitosana. 63

Figura 15 - Curva de viscosidade reduzida versus concentração da amostra de quitosana. 65

Figura 16 - Espectros no infravermelho para os óleos de copaíba: (-) OC(S), (-) $\mathrm{OC}(\mathrm{C})$ e $(-) \mathrm{OC}(\mathrm{E})$ 66

Figura 17 - Espectro no infravermelho para: (-) OC(S), (-) QG e (-) QGOC(S). .67

Figura 18 - Fotografia digital das emulsões: (A) QGOC(S), (B) QGOC(C) e (C) QGOC(E). Aumento de 10x. As setas indicam as gotículas dos óleos. 
Figura 19 - llustração das emulsões de QGOC submetidas aos ciclos de centrifugação: (A) sem centrifugar, (B) 1000 rpm, (C) 1500 rpm, (D) 2500 rpm, (E) 3000 rpm e (F) 3500 rpm.

Figura 20 - llustração das emulsões QGOC após as variações de temperatura: (A)

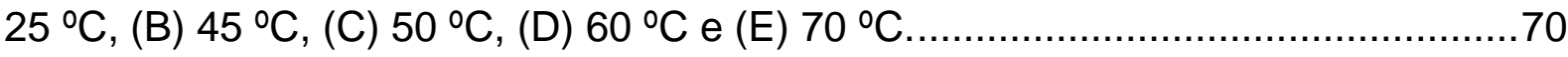

Figura 21 - llustração da determinação da CIM da linhagem de $S$. aureus, com as diferentes concentrações de $\mathrm{OC}(\mathrm{E})$. 73

Figura 22 - Ilustração da determinação da CIM da linhagem de $P$. aeruginosa, com as diferentes concentrações do gel QG. .76

Figura 23 - llustração da combinação dos antimicrobianos sobre $S$. aureus, com as diferentes concentrações da emulsão QGOC(E). .80

Figura 24 - llustração da combinação dos antimicrobianos da linhagem de $P$. aeruginosa, com as diferentes concentrações da emulsão QGOC(C). 81

Figura 25 - Curva de sobrevivência de $S$. aureus: (-) Controle e (-) QGOC(E) $\left(15,6 / 31,2 \mu \mathrm{g} \mathrm{m}^{-1}\right)$.

Figura 26 - Viabilidade celular dos compostos Controle Negativo, $\mathrm{OC}(\mathrm{S})$, $\mathrm{OC}(\mathrm{C}), \quad \mathrm{OC}(\mathrm{E}), \quad \mathrm{QG}, \quad \mathrm{QGOC}(\mathrm{S}), \quad \mathrm{QGOC}(\mathrm{C})$ e $\quad \mathrm{QGOC}(\mathrm{E})$ em diferentes concentrações. Sendo 1 = concentração inibitória mínima $(\mathrm{CIM}), 2=2 \mathrm{x}>\mathrm{CIM}$ e $4=$ $4 \mathrm{x}>\mathrm{CIM}$. 


\section{LISTA DE TABELAS}

Tabela 1 - Valores de pH das emulsões de quitosana/gelatina/óleo de copaíba submetidas aos diferentes testes de estabilidade.

Tabela 2 - Comparação entre o pH padrão do meio de cultura com o pH 5,5 utilizado nos ensaios de atividade antimicrobiana. .72

Tabela 3 - Valores de CIM e CBM dos diferentes óleos de copaíba (OC) sobre $S$. aureus. 72

Tabela 4 - Concentração inibitória mínima/concentração bactericida mínima de diferentes espécies do gênero Copaifera sobre $S$. aureus. 74

Tabela 5 - Valores de CIM e CBM do gel QG sobre $S$. aureus, E. coli e $P$. aeruginosa. .76

Tabela 6 - Valores de CIM e CBM das emulsões QGOC(S), QGOC(C) e QGOC(E).

Tabela 7 - Índice de sobrevivência celular da linhagem VERO para cada amostra de óleo de copaíba, gel de quitosana/gelatina e emulsão em concentrações diferentes. 


\section{LISTA DE ABREVIATURAS}

AN - Ágar Nutriente

ANVISA - Agência Nacional de Vigilância Sanitária

ATCC - American Type Culture Collection

CBM - Concentração Bactericida Mínima

CDC - Centers for Disease Control and Prevention

CIM - Concentração Inibitória Mínima

CLSI - Clinical and Laboratory Standards Institute

DMSO - Dimetilsulfóxido

DNA - Ácido desoxirribonucleico

D.O. - Densidade óptica

DP - Desvio Padrão

EDTA - Ácido etileno diamino tetracético

FTIR - Espectroscopia na região do infravermelho

GA - Grau de acetilação

GD - Grau de desacetilação

IS - Índice de Sobrevivência

$\mathrm{MH}$ - Caldo Müeller Hinton

MRSA - Methicillin-Resistant Staphylococcus aureus

MTT - Brometo de tetrazolium

OC - Óleo de copaíba

$\mathrm{OC}(\mathrm{C})$ - Óleo de copaíba adquirido no mercado municipal de Belém de coloração clara

$\mathrm{OC}(\mathrm{E})$ - Óleo de copaíba adquirido no mercado municipal de Belém de coloração escura

OC(S) - Óleo de copaíba oriundo de São Paulo

QG - Gel de quitosana/gelatina

QGOC(C) - Emulsão de quitosana/gelatina/óleo de copaíba claro 
QGOC(E) - Emulsão de quitosana/gelatina/óleo de copaíba escuro

QGOC(S) - Emulsão de quitosana/gelatina/óleo de copaíba de São Paulo

RMN ${ }^{1} \mathrm{H}$ - Ressonância Magnética Nuclear de Hidrogênio

RNAm - Ácido Ribonucleico mensageiro

rpm - Rotações por minuto

T - Temperatura

TSYEA - Ágar extrato de levedura triptona de soja

TSYEB - Caldo extrato de levedura triptona de soja

UFC $\mathrm{mL}^{-1}$ - Unidade formadora de colônias por mililitro

U.I. $\mathrm{mL}^{-1}$ - Unidades Internacionais por mililitro

$\mathrm{v} / \mathrm{v}$ - Volume por volume 


\section{SUMÁRIO}

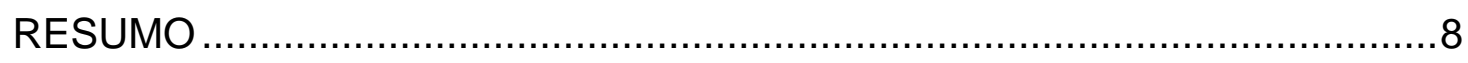

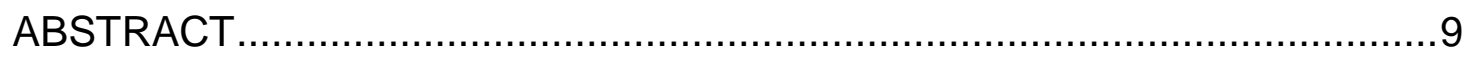

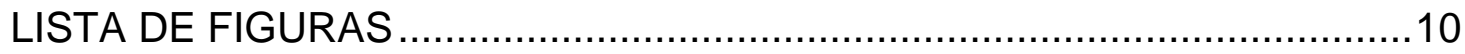

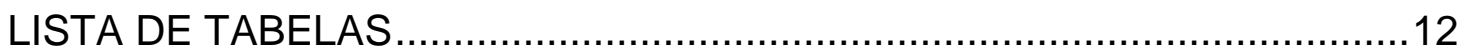

LISTA DE ABREVIATURAS …........................................................ 13

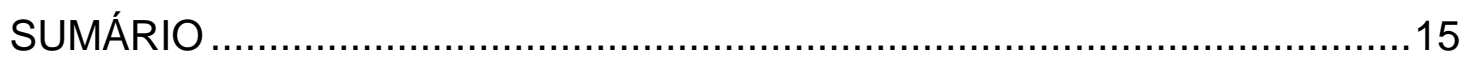

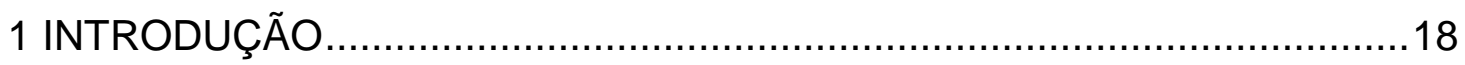

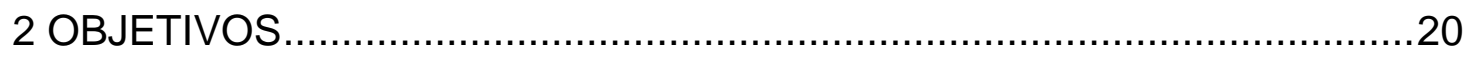

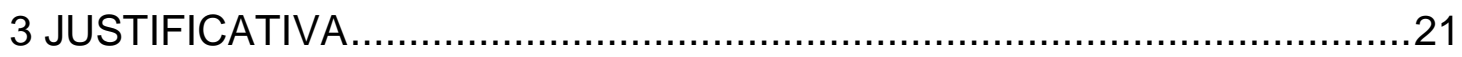

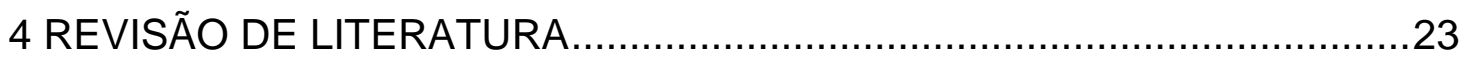

4.1 Ecologia e evolução bacteriana..............................................23

4.2 A microbiota da pele e infecções bacterianas ..................................24

4.3 Resistência bacteriana aos antibióticos .........................................29

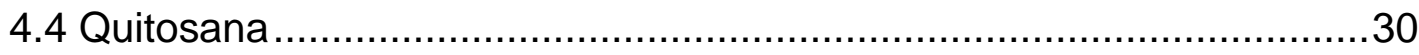

4.4.1 Atividade antimicrobiana da quitosana .....................................33

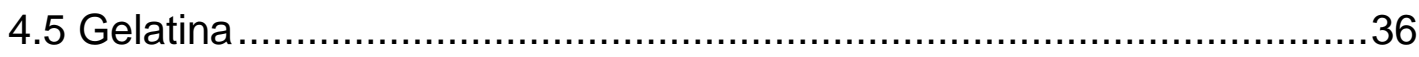

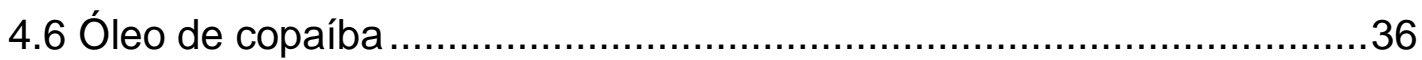

4.6.1 Atividade antimicrobiana do óleo de copaíba ............................39

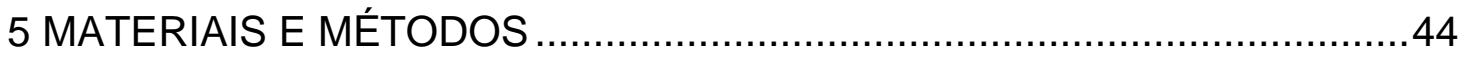

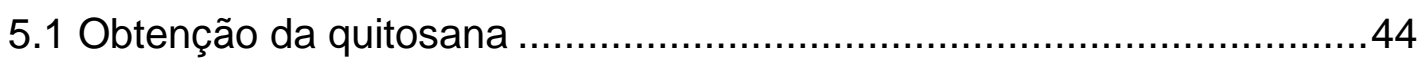

5.2 Caracterização da quitosana................................................ 45

5.2.1 Determinação do grau médio de acetilação por titulação

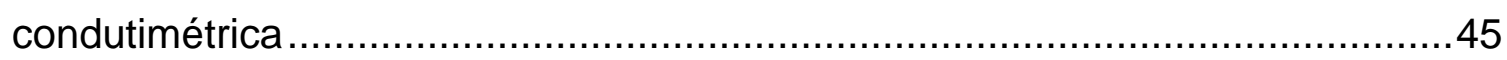

5.2.2 Determinação da massa molar média por viscosimetria ...............45

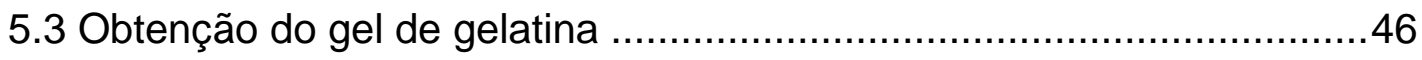


5.4 Óleos de copaíba

5.5 Preparo das amostras

5.5.1 Análise macroscópica e microscópica das emulsões

5.5.2 Testes de estabilidade das emulsões 49

5.5.3 Determinação dos valores de $\mathrm{pH}$ .50

5.6 Obtenção das linhagens bacterianas .50

5.7 Padronização do inóculo .51

5.8 Influência do pH no crescimento bacteriano .52

5.9 Teste de atividade antimicrobiana. 52

5.9.1 Preparo das soluções estoque para uso nos testes de atividade antimicrobiana. .53

5.9.2 Determinação da CIM dos óleos de copaíba e do gel de quitosana/gelatina .54

5.9.3 Determinação da interação antimicrobiana nas emulsões 56

5.9.4 Determinação da CBM 56

5.10 Curva de sobrevivência 57

5.10.1 Preparo das soluções estoque .57

5.10.2 Procedimento para obtenção da curva de sobrevivência 57

5.11 Ensaio de citotoxicidade 58

5.11.1 Determinação da viabilidade e concentração celular. 58

5.11.2 Preparo das amostras .59

5.11.3 Ensaio de citotoxicidade celular 60

6 RESULTADOS E DISCUSSÃO .62

6.1 Obtenção da quitosana 62

6.2 Caracterização da quitosana. 63

6.2.1 Determinação do grau médio de acetilação por titulação condutimétrica. .63

6.2.2 Determinação da massa molar média por viscosimetria .64 
6.3 Espectroscopia na região do infravermelho (FTIR) ......................66

6.4 Análise macroscópica e microscópica das emulsões..........................68

6.5 Testes de estabilidade das emulsões .............................................69

6.5.1 Teste de centrifugação .......................................................69

6.5.2 Estresse térmico ............................................................ 70

6.6 Determinação dos valores de $\mathrm{pH}$............................................ 71

6.7 Influência do $\mathrm{pH}$ no crescimento bacteriano .................................. 71

6.8 Atividade antimicrobiana dos óleos de copaíba ...............................72

6.9 Atividade antimicrobiana do gel de quitosana/gelatina......................75

6.10 Atividade antimicrobiana das emulsões de quitosana/gelatina/óleo de

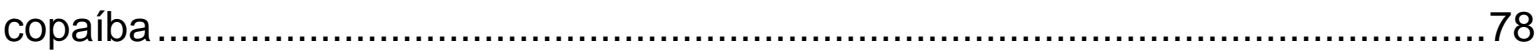

6.11 Curva de sobrevivência ............................................................. 83

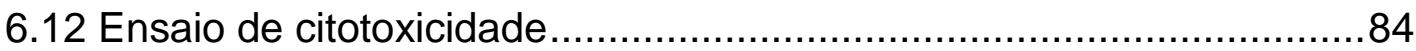

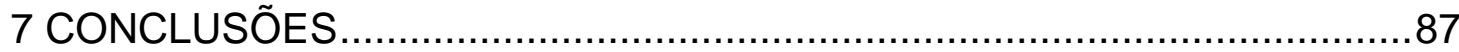

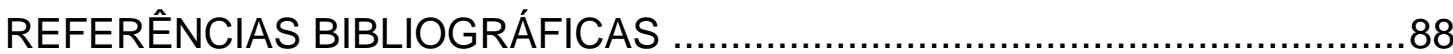




\section{INTRODUÇÃO}

A vida na Terra é caracterizada pela presença ancestral, contínua e massiva de bactérias nos mais variados habitats do planeta. Com o surgimento de organismos mais complexos, esses microrganismos precisaram desenvolver mecanismos evolutivos para aquisição de espaço e nutrientes que garantissem a sobrevivência (DETHLEFSEN; MCFALL-NGAI; RELMAN, 2007). Juntamente com o desenvolvimento evolutivo das bactérias muitas enfermidades também surgiram, porém, a elucidação de processos de higiene, vacinação e principalmente os antibióticos trouxeram benefícios incalculáveis para a população (BAKER, 2015; HOWARD; HOPWOOD; DAVIES, 2014; TORTORA; FUNKE; CASE, 2012; DETHLEFSEN; MCFALL-NGAl; RELMAN, 2007). Contudo, essa intervenção na relação microrganismo-hospedeiro sem considerar a ecologia e evolução microbiana favoreceu a disseminação da resistência microbiana aos antibióticos (TORTORA; FUNKE; CASE, 2012; DETHLEFSEN; MCFALL-NGAI; RELMAN, 2007).

Atualmente, o número de infecções, principalmente no ambiente hospitalar, provocadas por bactérias é alto e preocupa a comunidade científica devido à resistência cada vez maior aos antibióticos conhecidos, além disso, infecções causadas por bactérias super-resistentes levaram a um retrocesso do que foi vivenciado na era pré-antibiótico (BAKER, 2015; HOWARD; HOPWOOD; DAVIES, 2014). Diante desse cenário, são frequentes estudos alternativos na busca de produtos de origem natural com atividade antimicrobiana conhecida.

Dentre esses produtos está a quitosana, um copolímero obtido a partir da desacetilação parcial da quitina. A quitina é um polissacarídeo estrutural proveniente de diferentes biomassas como exoesqueleto de insetos, crustáceos, moluscos e micélio fúngico (GAVHANE; GURAV; YADAV, 2013). Este polímero por ser biodegradável, biocompatível, oferecer baixa toxicidade em mamíferos e apresentar uma gama de atividades biológicas vem despertando interesse nos mais diversos campos da ciência seja isolada ou em associação com outros polímeros naturais como amido, gelatina, alginato e com outros compostos como os óleos essenciais (DHILLON et al., 2013; GAVHANE; GURAV; YADAV, 2013; KONG et al., 2010).

A gelatina, outro polímero natural é obtido através da desnaturação das fibras de colágeno, seja por processamento químico ou tratamento térmico, que cliva 
as ligações de hidrogênio e covalentes desestabilizando a hélice tripla (GÓMEZGUILLÉN et al., 2011). Esse biopolímero tem sido associado a quitosana em muitos estudos envolvendo plastificantes, agentes reticulantes, emulsificantes dentre outros, alternativamente ao emprego de agentes químicos. A versatilidade desses biopolímeros ainda é mostrada na forma de sua aplicabilidade, ou seja, obter-se um sistema na forma de soluções, géis, membranas, filmes, esponjas, emulsões, esferas, nanopartículas, entre outros (GAVHANE; GURAV; YADAV, 2013; GÓMEZGUILLÉN et al., 2011).

Outro dos compostos comumente utilizados na medicina popular no tratamento de muitas doenças e no combate a vários patógenos é o óleo de copaíba (PIERI et al., 2010b; PIERI; MUSSI; MOREIRA, 2009). Este óleo resina é extraído do tronco de árvores do gênero Copaifera e é um composto abundante na rica flora do território brasileiro. Recentemente, foram relatados diversos estudos comprobatórios de suas propriedades conhecidas na medicina popular. Dentre essas propriedades destaca-se atividade anti-inflamatória, cicatrizante e antibiótica (PIERI et al., 2011; GOMES et al., 2010; MENDONÇA e ONOFRE, 2009; PIERI et al., 2009; SANTOS et al., 2008; PACKER e LUZ, 2007; VEIGA et al., 2007; PACHECO; BARATA; DUARTE, 2006).

Considerando o exposto acima, este trabalho pretende avaliar a atividade antimicrobiana de emulsões formadas pela combinação entre quitosana/gelatina/óleo de copaíba sobre bactérias patogênicas de interesse clínico. 


\section{OBJETIVOS}

Este estudo teve como objetivo principal avaliar o potencial antimicrobiano de diferentes óleos de copaíba, do gel de quitosana/gelatina e de emulsões de quitosana/gelatina/óleo de copaíba sobre as linhagens Staphylococcus aureus, Escherichia coli e Pseudomonas aeruginosa.

Objetivos específicos:

- Comparar o efeito antimicrobiano de óleos de copaíba oriundos de diferentes regiões;

- Avaliar a capacidade de incorporação dos óleos de copaíba em géis de quitosana/gelatina, formando emulsões;

- Determinar a concentração inibitória mínima e a concentração bactericida mínima dos óleos de copaíba, do gel de quitosana/gelatina e das emulsões de quitosana/gelatina/óleo de copaíba sobre as bactérias Staphylococcus aureus, Escherichia coli e Pseudomonas aeruginosa;

- Verificar a ocorrência de interação dos óleos de copaíba com o gel de quitosana/gelatina;

- Avaliar a citotoxicidade dos óleos de copaíba, do gel de quitosana/gelatina e das emulsões. 


\section{JUSTIFICATIVA}

A resistência antibiótica tem se espalhado mais rapidamente que a introdução de novos compostos devido principalmente ao uso indiscriminado e desnecessário de antibióticos na clínica médica, agricultura e veterinária. Não há uma nova classe de antibióticos no mercado desde 1987, e o que existe atualmente são antibióticos com efeito potencializado decorrente de modificações estruturais nos pré-existentes. Além disso, a indústria farmacêutica não recebe incentivo no desenvolvimento de novas moléculas antibióticas como recebe para desenvolver fármacos de uso contínuo em condições crônicas como os reguladores do colesterol e os anti-hipertensivos (HOWARD; HOPWOOD; DAVIES, 2014; TORTORA; FUNKE; CASE, 2012).

Portanto, a cooperação entre a academia e instituições privadas no desenvolvimento de novas moléculas sustentáveis, como estudos alternativos com o uso de compostos de origem natural, pode ser o primeiro e mais importante passo na resolução deste problema. Nesse cenário, estudos de compostos de origem natural com atividade antimicrobiana reconhecida são frequentes. Dentre esses compostos encontram-se os biopolímeros, como a quitosana e os fitoterápicos, como o óleo de copaíba.

A quitosana devido as suas propriedades como biodegradabilidade, biocompatibilidade e atoxicidade é um biopolímero que tem atraído grande interesse em pesquisa. A quitosana obtida a partir de gládios de lula ( $\beta$-quitina) tem propriedades diferenciadas, tais como, um peso molecular mais elevado e, assim, uma viscosidade intrínseca maior, melhores propriedades na forma de sua aplicabilidade formando filmes, esponjas, membranas, géis e emulsões em comparação com aquelas obtidas a partir de outras fontes como camarão ou caranguejo ( $\alpha$-quitina). Além disso, devido ao empacotamento menos denso, a $\beta$ quitina absorve mais umidade que a $\alpha$-quitina e isso está diretamente relacionado a atividade antimicrobiana, uma vez que, a solubilidade afeta a interação com a bactéria (KONG et al., 2010; CAMPANA-FILHO et al., 2007).

A natureza insolúvel dos óleos em água pode conferir uma sensação desagradável para uso tópico e o desenvolvimento de uma forma de dosagem tópica pode conferir benefícios relativos à estabilização do óleo e de penetração através da 
pele sendo assim, o desenvolvimento de uma emulsão é uma estratégia promissora para tratar infecções de pele, tais como infecções bacterianas. As emulsões podem ser definidas como micro gotículas de óleo dispersas em fase aquosa, estabilizadas por meio de um sistema tensoativo, representado neste trabalho pela presença de um agente emulsificante natural, a gelatina. Estes sistemas apresentam uma série de vantagens, como efeitos secundários reduzidos e aumento da penetração na pele, além da capacidade de estabilizar alguns fármacos, em comparação com formulações convencionais (DIAS et al., 2014).

Neste trabalho pretende-se estudar a obtenção e a atividade antimicrobiana de emulsões de quitosana/gelatina/óleo de copaíba visando sua futura aplicação clínica em infecções epidérmicas, uma vez que, a pele é a primeira barreira de proteção do corpo e a maior parte das infecções hospitalares são provocadas a partir do rompimento da integridade física, associado a debilidade imunológica do paciente.

Em suma, este estudo baseia-se na obtenção de emulsões que possam melhorar a atividade farmacológica dos compostos quitosana e óleo de copaíba isolados e com isso contribuir no desenvolvimento futuro de novas alternativas para tratamento de infecções. 


\section{REVISÃO DE LITERATURA}

\subsection{Ecologia e evolução bacteriana}

A vida na Terra é caracterizada pela presença ancestral de bactérias nos mais diversos habitats do planeta (Figura 1). A população microbiana é $10^{14}$ maior que a população humana (7.000.000.000) e em comparação aos seres vivos do planeta estima-se que seja a metade em abundância $\left(5 \times 10^{30}\right)$. Estes organismos estão intrinsecamente ligados aos ambientes em que habitam, são os maiores geradores de oxigênio e sua diversidade é tamanha que apenas conhece-se $30 \%$ destes, pois os demais são incultiváveis nos meios de crescimento conhecidos (BOZZA e MUCIDA, 2013).

Figura 1 - O relógio da vida na Terra.

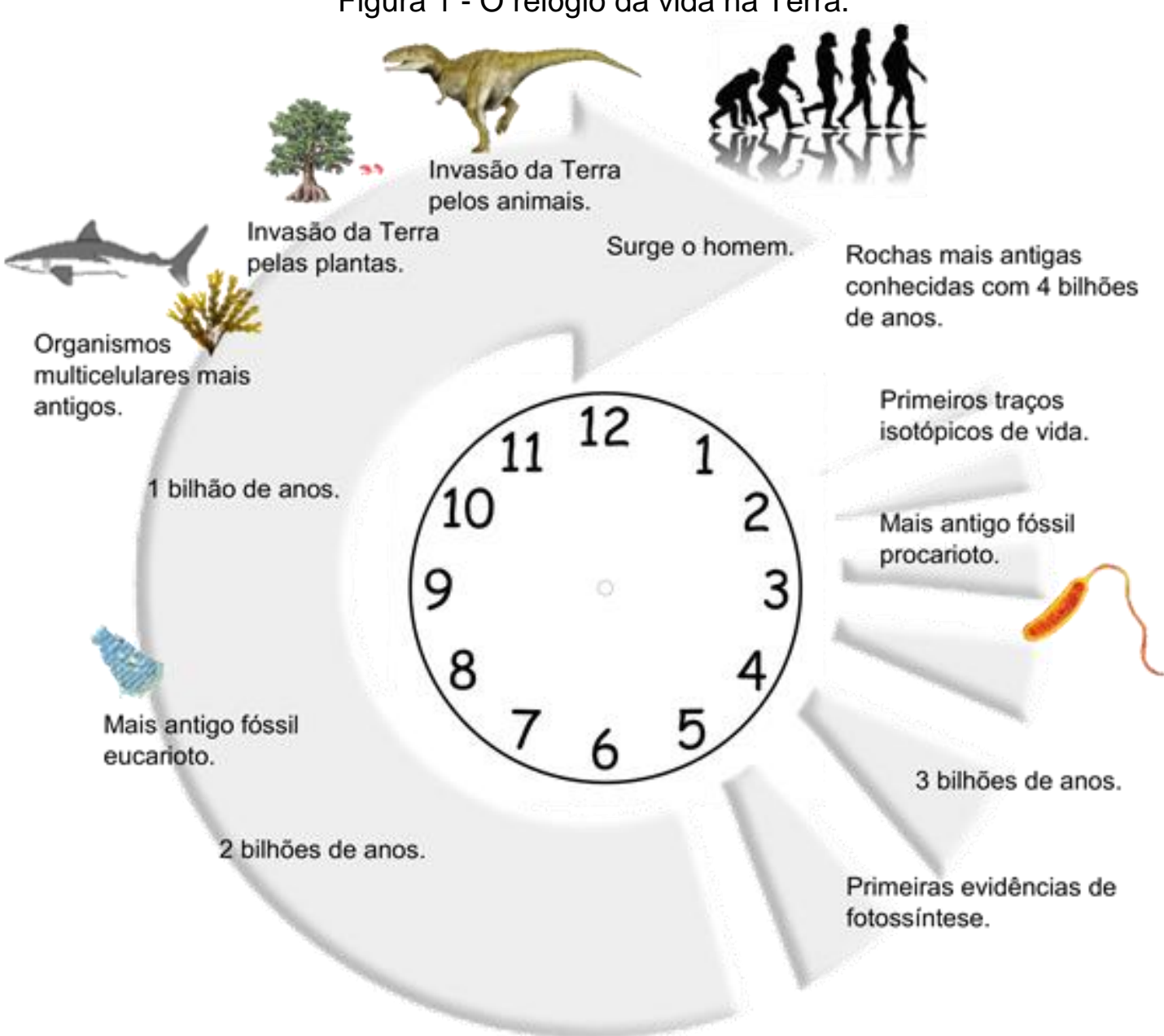

Fonte: Adaptado de BOZZA e MUCIDA, 2013. 
As bactérias estão largamente distribuídas na natureza, fazem parte da microbiota natural dos humanos e animais revestindo a pele, mucosas e cobrindo o trato gastrointestinal, sendo que o número de bactérias, corresponde a 100 vezes o número de células do corpo humano (DETHLEFSEN; MCFALL-NGAI; RELMAN, 2007).

Muitas bactérias são benéficas para seu hospedeiro (homem, animais, plantas) e provêm nutrientes ou proteção contra patógenos e doenças, limitando a habilidade de colonização de microrganismos nocivos. Entre as funções da microbiota está o efeito barreira, onde por competição/exclusão de habitats ou pela produção de peptídeos antimicrobianos (bacteriocinas) ocorre o impedimento da colonização de bactérias causadoras de doenças, sendo tal efeito de suma importância no maior órgão e primeira barreira de proteção do corpo humano, a pele. Além disso, a microbiota é responsável pela manutenção da homeostase e apresenta um importante papel na evolução humana em geral, especialmente no estabelecimento do sistema imune. $O$ desequilíbrio nesse processo pode provocar a colonização de bactérias patógenas ou até mesmo fazer com que as bactérias que compõem a microbiota invadam o tecido do hospedeiro e tornem-se causadoras de infecções oportunistas. Isso demonstra o papel central da microbiota na manutenção da saúde e o seu desequilíbrio na gênese de diversas patologias (DETHLEFSEN; MCFALL-NGAl; RELMAN, 2007).

\subsection{A microbiota da pele e infecções bacterianas}

A pele é a primeira linha de defesa do organismo, como uma barreira física, limita o crescimento e penetração de bactérias patogênicas. A pele de um indivíduo adulto médio ocupa uma área de cerca de $1,9 \mathrm{~m}^{2}$ e varia em espessura de 0,05 a 3,0 mm e compõe-se de duas partes principais: a epiderme e a derme (Figura 2).

A epiderme é a parte mais fina e externa da pele, composta por diversas camadas epiteliais. A camada mais externa da epiderme recebe o nome de estrato córneo e contém várias fileiras de células mortas onde predomina a proteína queratina. A epiderme, quando intacta, é uma barreira efetiva contra microrganismos. A derme é a camada mais interna da pele e é composta 
especificamente de tecido conectivo. Os folículos pilosos e as glândulas sebáceas e sudoríparas presentes proporcionam uma via de passagem por onde os microrganismos podem adentrar aos tecidos mais profundos (TORTORA; FUNKE; CASE, 2012).

Figura 2 - A estrutura da pele humana

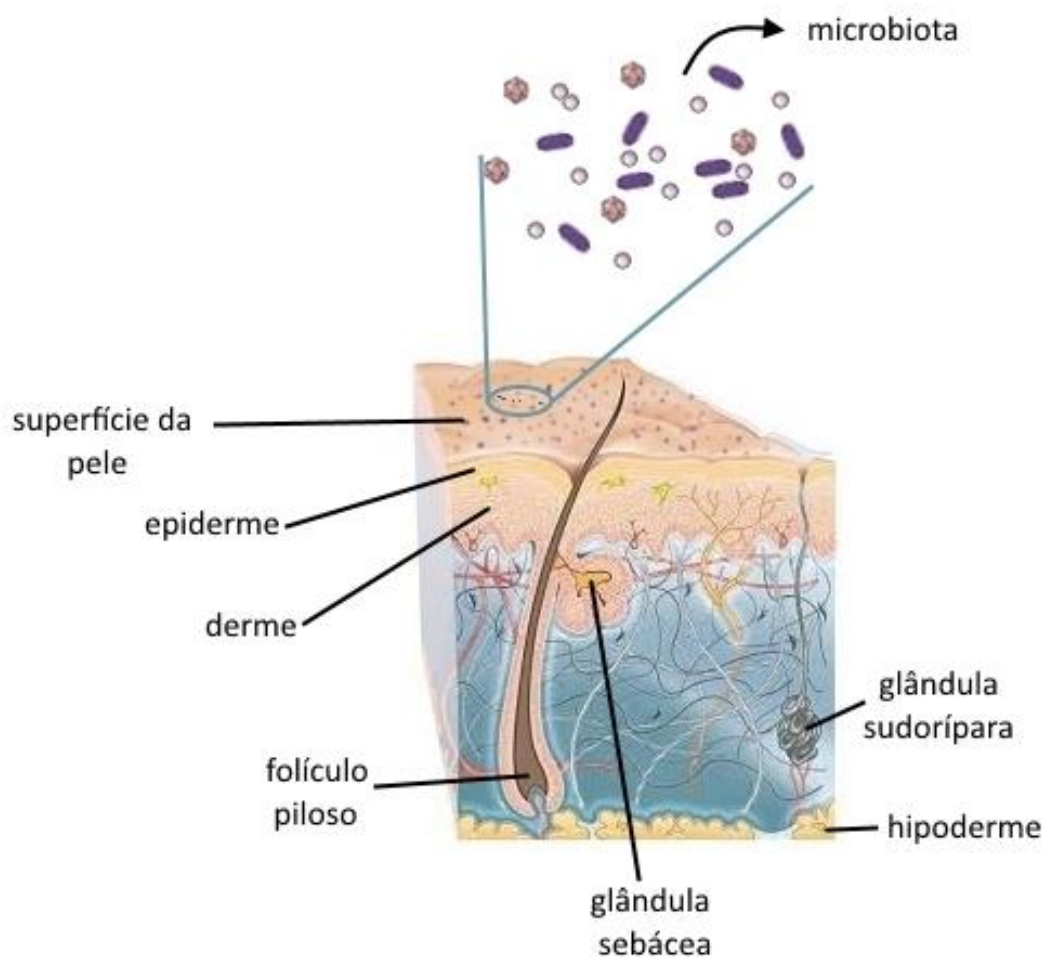

Fonte: Adaptado de GOMES, 2015.

A pele é um ambiente desfavorável para o crescimento bacteriano, pois apresenta rigidez mecânica fornecida pelo estrato córneo, secreções ácidas que conferem baixo $\mathrm{pH}(3,0-5,0)$, pouca umidade, presença de lisozima e de antibióticos peptídicos. Embora isso aconteça, a pele oferece suporte ao crescimento de microrganismos que se estabeleceram como parte da microbiota normal (TORTORA; FUNKE; CASE, 2012; GRICE e SEGRE, 2011).

A microbiota da pele compõe-se por um número relativamente alto de bactérias Gram-positivas como Staphylococcus e Micrococcus. As áreas do corpo que apresentam maior umidade, como as axilas e a região entre as pernas suportam um maior número de microrganismos, que metabolizam as secreções provenientes das glândulas sudoríparas e são responsáveis pelo odor corporal. Também fazem parte da microbiota normal, bacilos Gram-positivos, como Propionibacterium acnes que habitam os folículos pilosos, metabolizando as secreções advindas das 
glândulas sebáceas e produzem ainda, o ácido propiônico que ajuda na manutenção do $\mathrm{pH}$ da pele entre 3-5. Outros como Corynebacterium xerosis, ocupam a superfície da pele, além da levedura Malassezia furfur (TORTORA; FUNKE; CASE, 2012; GRICE e SEGRE, 2011).

A homeostasia na relação microrganismo-hospedeiro e o entendimento da microbiota são cruciais na tentativa de evitar o desenvolvimento de doenças e/ou tratá-las. O rompimento da primeira barreira de proteção, fornecida pela integridade física da pele pode provocar a colonização de bactérias patógenas ou até mesmo fazer com que bactérias que compõem a microbiota invadam o tecido do hospedeiro e tornem-se causadoras de infecções oportunistas (GRICE e SEGRE, 2011).

Esse cenário é extremamente preocupante no contexto das infecções hospitalares, uma vez que, a debilidade imunológica do paciente pode favorecer o agravamento do quadro clínico. As infecções mais frequentes são urinárias, feridas cirúrgicas e pneumonias, bem como as provocadas pela utilização de dispositivos invasivos como cateteres urinários e intravasculares, a intubação traqueal e a ventilação mecânica. Além disso, destacam-se também, as bacteremias sejam estas resultantes de um processo primário e sem fonte identificável ou mais frequentemente associadas a um método invasivo, como os cateteres intravasculares, arteriais ou venosos, centrais ou periféricos e nutrição parenteral (HEALTHY PEOPLE, 2013; GRICE e SEGRE, 2011; SYDNOR e PERL, 2011).

Dentre os patógenos mais comumente isolados nessas infecções encontram-se as bactérias Staphylococcus aureus, Escherichia coli e Pseudomonas aeruginosa (CDC, 2015).

S. aureus pertence a um grupo diversificado de bactérias Gram positivas, apresenta-se na forma de cocos isolados, aos pares ou formando cadeias e cachos de uvas. São imóveis, não formam endósporos, são anaeróbios facultativos, suas colônias são opacas e podem ter coloração esbranquiçada ou creme e algumas vezes amarelo-douradas. Geralmente são catalase e citocromo positivos, mas oxidase negativos, reduzem o nitrato a nitrito e não são susceptíveis a lise pela lisozima. Crescem bem em $\mathrm{NaCl}$ e apresentam temperatura ótima entre 30-37 으 (HOLT et al., 1994).

As doenças causadas por $S$. aureus vão desde infecções de pele a infecções fatais como bacteremia. Essa bactéria está entre as causas mais frequentes de infecções nosocomiais e infecções associadas ao uso de dispositivos 
médicos, também é a principal causa de infecções associadas com a formação de biofilme. Staphylococcus aureus tornou-se um enorme problema de saúde pública, seja nas infecções hospitalares ou adquiridas na comunidade, uma vez que, já colonizou cerca de um terço da população mundial, sendo residente permanente das passagens nasais de $20 \%$ da população e cerca de $60 \%$ a carreiam ocasionalmente. Exposta em superfícies pode sobreviver por meses estando diretamente relacionado à formação de biofilmes. Apresenta grande resistência aos antibióticos tradicionais, uma vez que, seu genoma é composto por cerca de 300.000 pares de bases em relação a outra espécie do gênero, inferindo em uma gama de fatores de virulência e meios de evadir as defesas do hospedeiro. Isso limita a eficácia terapêutica e tornase um problema para o tratamento de infecções crônicas (TORTORA; FUNKE; CASE, 2012; CDC, 2011; SYDNOR e PERL, 2011; HOLT et al., 1994).

E. coli é um bastonete Gram negativo pertencente à família Enterobacteriaceae. Essa família possui grande importância microbiológica e médica devido às infecções causadas, patogenicidade e ao surgimento de bactérias multirresistentes aos antibióticos utilizados na terapêutica.

A maioria dos gêneros e espécies pertencentes à família Enterobacteriaceae apresentam as seguintes características: são bastonetes Gramnegativos curtos e retos, não formam endósporos, possuem motilidade peritríquia, desenvolvem-se em peptona ou extrato de carne sem a adição de suplemento ou cloreto de sódio, como também em ágar MacConkey, são anaeróbias facultativas, crescem bem a $37{ }^{\circ} \mathrm{C}$, fermentam glicose e outros açúcares, reduzem nitrato a nitrito, contém antígenos comuns enterobacterianos e têm 39 a $59 \%$ de guaninacitosina (G-C) no DNA (FARMER III; BOATWRIGHT; JANDA, 2007).

Estas bactérias estão dispersas na natureza e podem ser encontradas em plantas, solo, água e microbiota normal do trato intestinal dos animais e seres humanos. Podem estar associadas a infecções comunitárias e hospitalares, oportunistas ou não. Muitas espécies são causadoras de infecções urinárias, intestinais, feridas cirúrgicas, abscessos, pneumonias, sepses e meningites (FARMER III; BOATWRIGHT; JANDA, 2007). Enterobacteriaceae são responsáveis por, aproximadamente, $50 \%$ das infecções hospitalares, especificamente os casos de sepse e $70 \%$ dos casos de infecção do trato urinário (FARMER III; BOATWRIGHT; JANDA, 2007; HOLT et al., 1994). 
Destaca-se ainda, o importante papel de bactérias não fermentadoras no panorama de multirresistência, principalmente em relação às infecções nosocomiais. Dentre essas bactérias, Pseudomonas é um dos gêneros de maior importância clínica, pois é um dos agentes mais isolados em laboratórios de microbiologia e frequentemente demonstram resistência, intrínseca e adquirida, a várias classes de antibióticos (BONOMO; SZABO, 2006; PATERSON, 2006). Pseudomonas spp. são bastonetes Gram-negativos, aeróbicos, podem ser observados como células isoladas, aos pares ou em cadeias curtas, revelando mobilidade através de flagelo polar monotríqueo, encontram-se amplamente distribuídas no solo e em fontes de água, são capazes de crescer em qualquer ambiente úmido e em matérias orgânicas pouco comuns, como filmes de sabão ou adesivos selantes (TORTORA; FUNKE; CASE, 2012; FERREIRA, 2005).

Atualmente, representa um dos gêneros mais ubíquos, sendo Pseudomonas aeruginosa a principal espécie de interesse clínico, especialmente em indivíduos com infecções provocadas por queimaduras (TORTORA; FUNKE; CASE, 2012; GRICE e SEGRE, 2011; PEIX; RAMÍREZ-BAHENA; VELÁSQUEZ, 2009). Essa bactéria produz diversas exotoxinas, que são responsáveis pela maior parte de sua patogenicidade, e uma endotoxina. Frequentemente, cresce em densos biofilmes que contribuem para sua identificação recorrente como causa de infecções hospitalares de cateteres ou dispositivos médicos. As infecções podem gerar pus de coloração azul-esverdeada (TORTORA; FUNKE; CASE, 2012; FARMER III; BOATWRIGHT; JANDA, 2007).

Atualmente, o número de infecções, principalmente no ambiente hospitalar, provocadas por bactérias é alto e preocupa a comunidade científica devido à resistência cada vez maior aos antibióticos conhecidos. Além disso, infecções causadas por bactérias super-resistentes levaram a um retrocesso do que foi vivenciado na era pré-antibiótico. Somente, na Europa e nos Estados Unidos, estimativas sugerem que 25.000 e 23.000 pessoas/ano, respectivamente apresentam óbito devido a infecções causadas por bactérias resistentes a antibióticos (BAKER, 2015; HOWARD; HOPWOOD; DAVIES, 2014). 


\subsection{Resistência bacteriana aos antibióticos}

A resistência aos antibióticos representa um desafio mundial, uma vez que, o surgimento de novos recursos terapêuticos não acompanha a evolução bacteriana (LING et al., 2015). O desenvolvimento de resistência é um processo natural da evolução, ou seja, o desenvolvimento evolutivo das bactérias à medida em que organismos mais complexos surgiam desencadeou o aparecimento de muitas enfermidades. Contudo, a assepsia das mãos, a vacinação e principalmente o aparecimento dos antibióticos com o marco histórico da penicilina nos anos 1940 trouxe benefícios incalculáveis para a população (BAKER, 2015; HOWARD; HOPWOOD; DAVIES, 2014; TORTORA; FUNKE; CASE, 2012; DETHLEFSEN; MCFALL-NGAI; RELMAN, 2007). Essa intervenção na relação microrganismohospedeiro sem considerar a ecologia e evolução microbiana trouxe à tona a resistência aos antibióticos recém-lançados (TORTORA; FUNKE; CASE, 2012; DETHLEFSEN; MCFALL-NGAI; RELMAN, 2007).

São diversos os mecanismos em que a bactéria adquire resistência ao antibiótico como: produção de enzimas que degradam ou inativam o antibiótico, alteração da permeabilidade da membrana que dificulta ou impede a penetração do antibiótico na célula, alteração do sítio alvo do antibiótico ou efluxo do antibiótico, como mostra a Figura 3 (TORTORA; FUNKE; CASE, 2012; DAVIES e DAVIES, 2010).

Figura 3 - Principais mecanismos de resistência microbiana a agentes antimicrobianos.

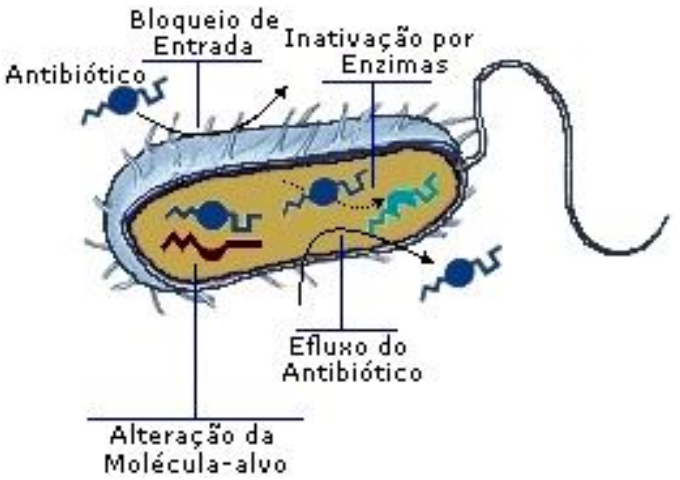

Fonte: Adaptado de TORTORA; FUNKE; CASE, 2012. 
A resistência bacteriana é um processo adaptativo que resulta de alguns eventos e pode apresentar 4 origens (TORTORA; FUNKE; CASE, 2012; DAVIES e DAVIES, 2010):

- intrínseca: naturalmente existente na bactéria, podendo ocorrer sem o contato prévio com o antibiótico (resistência constitutiva) ou quando o antibiótico inicialmente tem ação, mas após algum tempo ocorre a expressão da resistência selecionando as bactérias que a expressaram (induzida);

- mutações em genes que passam a conferir resistência;

- fisiológica ligada intimamente a formação de biofilmes bacterianos (matriz polissacarídica) protegendo a bactéria da ação dos antibióticos;

- adquirida em que ocorre a aquisição de genes de resistência.

A resistência adquirida é a mais frequente e importante, podendo ocorrer por transmissão vertical, ou seja, quando uma bactéria se divide todo o seu genoma é duplicado originando uma nova célula idêntica, ou por transmissão horizontal, na qual bactérias de espécies iguais ou diferentes trocam genes de resistência por transferência de DNA através de processos como, transdução, conjugação e transformação (TORTORA; FUNKE; CASE, 2012; DAVIES e DAVIES, 2011).

Dados da literatura apontam mais de 20.000 genes de resistência independentemente da interação da bactéria com o antibiótico na prática. De fato, acreditava-se que os mecanismos evolutivos de resistência aconteciam no momento da interação com o antibiótico, entretanto já se sabe que a bactéria pode apresentar resistência sem o contato prévio com o antibiótico, um bom exemplo disso, é o $S$. aureus resistente ao ácido nalidíxico e ácido pipemídico. Contudo, a interação com o antibiótico pode favorecer a formação de biofilmes e fatores de virulência, sem, no entanto, ser um fator isolado (HOWARD; HOPWOOD; DAVIES, 2014; DAVIES e DAVIES, 2011).

\subsection{Quitosana}

A quitosana é um copolímero composto por unidades 2-acetamida-2desoxi-D-glicopiranose e 2-amino-2-desoxi-D-glicopiranose, obtido a partir da desacetilação parcial da quitina (Figura 4). A quitina é um polissacarídeo natural 
presente na biomassa de insetos, crustáceos como camarão, lagosta, caranguejo, endoesqueleto de lula e micélio fúngico, sendo este biopolímero responsável por formar os componentes estruturais e desempenhar funções de reforço nos organismos em que está presente (RINAUDO, 2006).

Figura 4 - Estrutura da quitosana obtida a partir da desacetilação parcial da quitina.

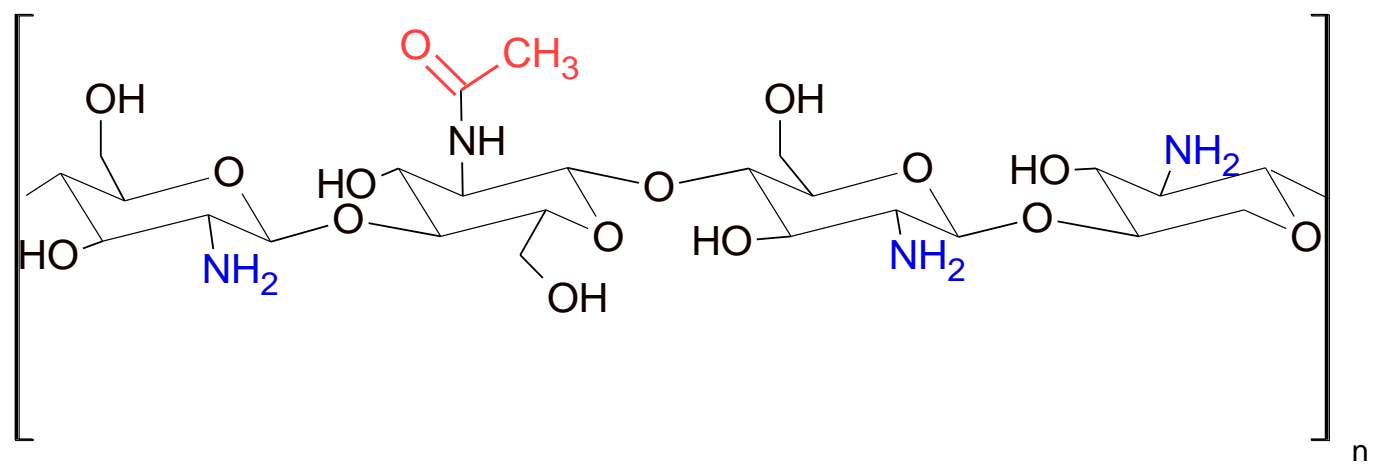

Fonte: Autoria própria.

Dependendo da fonte, a estrutura da quitina pode ser encontrada em três formas cristalinas diferentes $\alpha, \beta$ e $\gamma$. A $\alpha$-quitina é a mais abundante e ocorre em crustáceos, insetos e na parede celular fúngica, apresentando-se em um arranjo de cadeias alternadas paralelas e antiparalelas. Já a $\beta$-quitina, é encontrada em associação com proteínas em gládios de lulas e compõe-se de um arranjo de cadeias paralelas e $\gamma$-quitina parece ser uma combinação dos arranjos de $\alpha$ e $\beta$ quitina e ainda não é bem conhecida, sendo relatada como uma variante da família $\alpha$ (CAMPANA-FILHO et al., 2007; RINAUDO, 2006). A quitina utilizada neste estudo foi obtida de gládios de lula, com estrutura polimórfica na forma $\beta$. Quando comparada com a a-quitina, esta apresenta solubilidade em um maior número de solventes, maior reatividade no processo de desacetilação e maior intumescimento, ampliando a versatilidade na forma de sua aplicabilidade (GAVHANE; GURAV; YADAV, 2013; RINAUDO, 2006).

A quitina passa a ser chamada de quitosana quando o grau de acetilação é menor que $50 \%$. A quitina é insolúvel em solução aquosa e em solventes orgânicos, o que a torna de difícil aplicação. No entanto, a quitosana é mais adequada para aplicações biológicas e é completamente solúvel em soluções de ácidos fracos e diluídos. A solubilização ocorre através da protonação dos grupos $\mathrm{NH}_{2}$ da posição $\mathrm{C} 2$ da unidade repetitiva da glicosamina o que confere carga positiva ao polímero. Portanto, a solubilidade é diretamente proporcional ao grau de 
acetilação, uma vez que, esta é afetada pela quantidade de grupos acetamida presentes na cadeia do polissacarídeo. O pKa dos grupos amino protonados é de aproximadamente 6,5 , ocorrendo a precipitação da quitosana na forma de flocos gelatinosas em pH superiores a este (KONG et al., 2010; RINAUDO, 2006).

A quitosana vem despertando o interesse nos mais diversos campos da ciência, como na agricultura, indústria alimentícia, indústria farmacêutica e de cosméticos devido a propriedades como a biocompatibilidade, a biodegradabilidade e a atoxicidade (DHILLON et al., 2013; GAVHANE; GURAV; YADAV, 2013). Além disso, a possibilidade de ser quimicamente modificada, processada em diferentes formas (soluções, géis, membranas, filmes, esponjas, emulsões, esferas, nanopartículas, entre outros) e de ser um polieletrólito em meio ácido são características que fazem da quitosana um polissacarídeo em potencial para um número expressivo de aplicações, seja em sua forma isolada ou em associação com outros polímeros naturais como amido, gelatina, alginato e com outros compostos como os óleos essenciais (GAVHANE; GURAV; YADAV, 2013; KONG et al., 2010). Entre as aplicações apresentadas pela quitosana estão: ação antimicrobiana (bactericida, bacteriostática, fungicida e fungistática), antitumoral, agente anticoagulante, agente hemostático, imunoestimulador, agente cicatrizante, antiinflamatório, modulador das funções renais, antiviral, antioxidante, redutor dos níveis colesterolêmicos (DHILLON et al., 2013; GAVHANE; GURAV; YADAV, 2013) (Figura $5)$.

A quitosana e seus derivados têm sido amplamente estudados em termos da atividade bacteriostática e bactericida. Estudos recentes mostram a eficácia da quitosana na inibição do crescimento de microrganismos patogênicos, como bactérias, leveduras e fungos (JEON et al., 2014; DHILLON et al., 2013; KONG et al., 2010). Várias teorias têm sido propostas na tentativa de explicar o modo de ação que leva à atividade antimicrobiana da quitosana que ainda não é totalmente compreendido. 
Figura 5 - Esquema das possíveis aplicações para a quitosana.

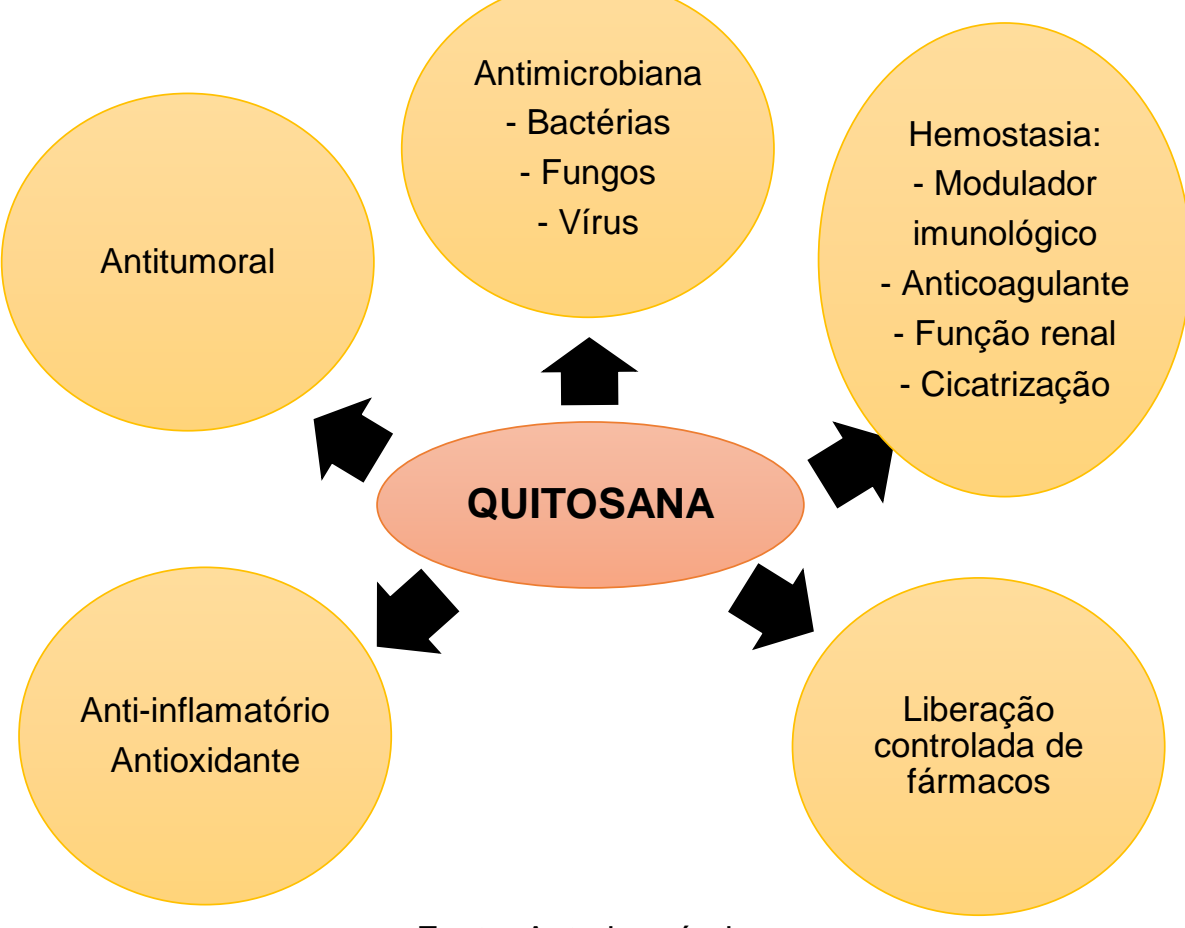

Fonte: Autoria própria.

\subsubsection{Atividade antimicrobiana da quitosana}

Três mecanismos foram propostos para explicar a atividade antibacteriana da quitosana. O mais aceito atualmente consiste na interação entre as moléculas de quitosana carregadas positivamente, devido a presença de grupos amino protonados, e a superfície bacteriana carregada negativamente. Essa interação causa o rompimento da membrana celular levando ao extravasamento dos constituintes intracelulares e, consequentemente, a morte da célula, como exemplificado na Figura 6 (JEON et al., 2014; KONG et al., 2010; RABEA et al., 2003; HELANDER et al., 2001; SUDARSHAN; HOOVER; KNORR, 1992).

Jeon et al. (2014) confirmaram o mecanismo anteriormente mencionado em que o efeito bactericida da quitosana está associado à capacidade de romper a membrana celular. Estudos moleculares de micropartículas de quitosana utilizando métodos in vitro e in vivo frente a bactéria $E$. coli $0157: \mathrm{H} 7$, importante patógeno causador da síndrome hemolítica renal, revelaram a ligação da quitosana com uma proteína presente na membrana externa do microrganismo (OmpA), demonstrando a ocorrência de interação eletrostática. 
Figura 6 - llustração do efeito antimicrobiano da quitosana.

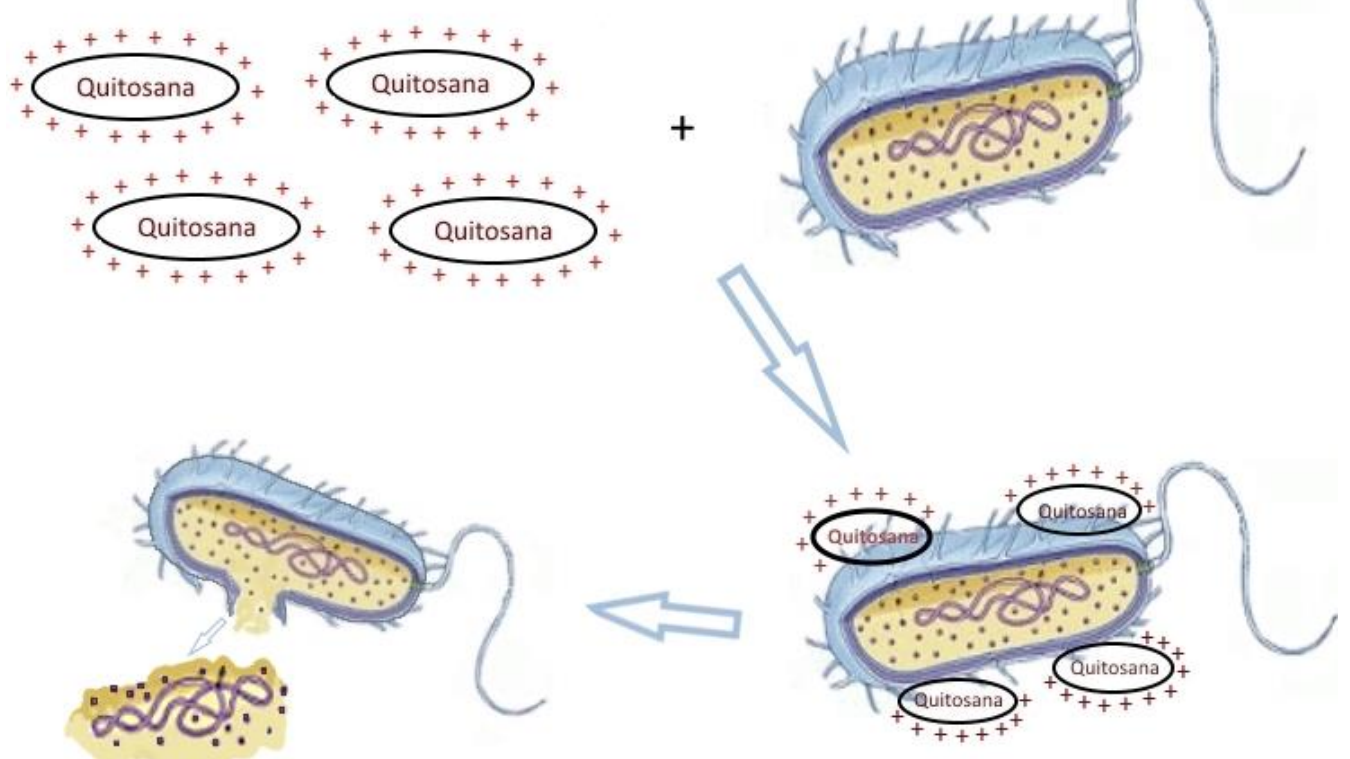

Fonte: Autoria própria.

Um segundo mecanismo de ação da quitosana está relacionado com a capacidade de oligômeros de quitosana de atravessar a parede celular da bactéria, inibindo o RNAm e a síntese proteica através da ligação direta da quitosana ao DNA do microrganismo, interferindo assim na maquinaria celular (SEBTI et al., 2005; SUDARSHAN; HOOVER; KNORR, 1992; HADWIGER et al., 1981).

O terceiro mecanismo proposto está relacionado à capacidade de quelação de metais da quitosana, não apenas sob condições ácidas, mas também em $\mathrm{pH}$ neutro, especialmente em derivados de quitosana com modificações nos grupos lipofílicos. Neste caso, a quitosana liga-se a metais presentes na parede celular do microrganismo e limita a passagem de nutrientes essenciais a vida da célula bacteriana, sendo a hidrofobicidade e a ação quelante responsáveis pela atividade antimicrobiana (WANG et al., 2005; HELANDER et al., 2001; ROLLER e COVILL, 1999).

Independentemente do mecanismo de ação, a atividade antimicrobiana da quitosana é influenciada por vários fatores como: grau de acetilação, massa molar, concentração e capacidade de quelação (fatores intrínsecos); solubilidade; $\mathrm{pH}$, força iônica e temperatura (fatores extrínsecos), além do tipo de microrganismo e tempo de exposição deste à quitosana (DHILLON et al., 2013; KONG et al., 2010; GOY; BRITTO; ASSIS, 2009). 
Younes et al. (2014) investigaram a influência do grau de acetilação e da massa molar na atividade antibacteriana da quitosana e observaram que quanto menor o grau de acetilação e o $\mathrm{pH}$, maior a eficácia da quitosana. Além disso, os autores verificaram que os efeitos da quitosana foram diferentes para as bactérias Gram-positivas e Gram-negativas, sendo as primeiras melhor inibidas por quitosana de maior massa molar. Em contrapartida, a quitosana de menor massa molar, foi mais eficiente para as bactérias Gram-negativas.

Em outro estudo relatado por Mellegard et al. (2011), também foi avaliada a influência do grau de acetilação e da massa molar na atividade antimicrobiana da quitosana e os autores corroboram que quanto menor o grau de acetilação, melhor a atividade bactericida da quitosana. Contudo, os autores não verificaram diferenças significativas em relação a massa molar.

Outro aspecto importante é a solubilidade da quitosana, que está relacionado com a quantidade de grupos protonados $\left(-\mathrm{NH}_{3}{ }^{+}\right)$no polímero. O pKa dos grupos $-\mathrm{NH}_{3}{ }^{+}$é de aproximadamente 6,5. Portanto, aumentando-se o pH da solução acima deste valor, a quitosana precipita na forma de flocos gelatinosos. Sabe-se que quanto mais solúvel a quitosana, maior é sua atividade bactericida (KONG et al., 2010) e por esse fato os derivados de quitosana são mais eficazes na inibição bacteriana. Isso acontece, pois, o grau de substituição e o tipo de substituinte presente na cadeia polimérica altera o pKa das moléculas fazendo com que a protonação aconteça em uma maior faixa de $\mathrm{pH}$, ampliando assim a solubilidade (KONG et al., 2010).

Além do $\mathrm{pH}$, a alteração da força iônica no meio pode bloquear a atividade inibitória da quitosana, seja pelo aumento de íons metálicos prejudicando a capacidade quelante da quitosana ou, pela presença de cátions no meio, que competem com a quitosana pelos componentes negativos da parede celular bacteriana. Ainda, fatores como o tempo de armazenamento e a temperatura alteram a viscosidade e a massa molar da quitosana podendo afetar a atividade antimicrobiana (KONG et al., 2010).

As características ligadas ao microrganismo mostram diferentes perfis de sensibilidade. Vários autores relatam um maior efeito inibitório em bactérias Grampositivas do que em Gram-negativas, devido às diferenças encontradas na superfície celular das bactérias. Outras pesquisas mostram que bactérias Gramnegativas são mais susceptíveis em relação às Gram-positivas por serem mais 
hidrofílicas. Ainda há autores que não observaram diferenças significativas de sensibilidade entre as bactérias (KONG et al., 2010; GOY; BRITTO; ASSIS, 2009).

A variabilidade das características associadas a quitosana, desde a natureza da matéria-prima e condições empregadas na obtenção até o tipo de microrganismo podem levar a diferentes modos de interação e as variações de sensibilidade encontradas.

\subsection{Gelatina}

A gelatina, também é um polímero natural, obtido através da desnaturação das fibras de colágeno, seja por processamento químico ou tratamento térmico, que cliva as ligações de hidrogênio e covalentes desestabilizando a hélice tripla (Figura 7) (GÓMEZ-GUILLÉN et al., 2011). Há muitos estudos em que esse biopolímero é associado a quitosana para melhorar determinadas características. Entre essas propriedades estão a solubilidade, faixa de $\mathrm{pH}$, viscosidade e a interação com outros compostos, como os óleos essenciais permitindo o processo de emulsificação sem a necessidade do uso de tensoativos e compostos químicos (GAVHANE; GURAV; YADAV, 2013; PEREDA et al., 2011; GÓMEZ-ESTACA et al., 2010).

Figura 7 - Estrutura do colágeno e da gelatina.

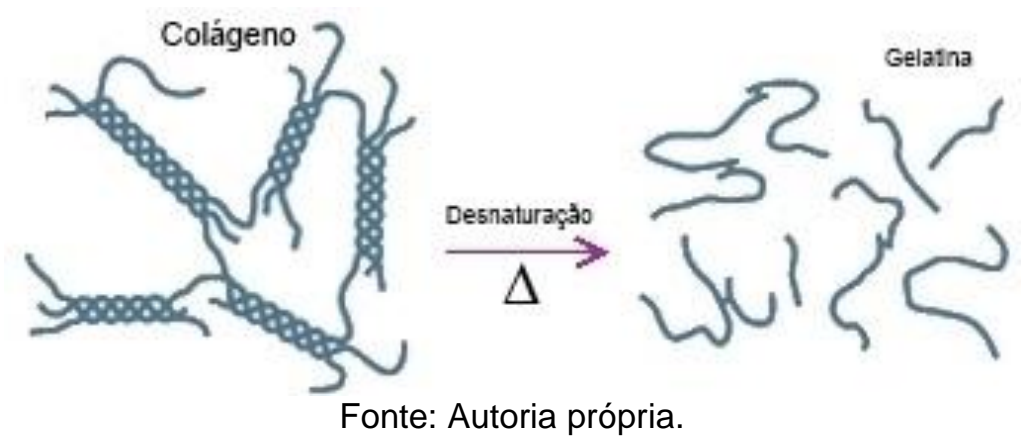

\section{6 Óleo de copaíba}

O óleo de copaíba é extraído do tronco de árvores do gênero Copaifera As copaibeiras são árvores da família das Leguminosae-Caesalpinoideae, de 
crescimento lento, podem alcançar até 40 metros de altura e chegam a viver cerca de 400 anos. O tronco é áspero, de coloração escura, medindo de 0,4 a 4 metros de diâmetro e são comuns à América Latina e África Ocidental (DIAS et al., 2014; LEANDRO et al., 2012; PIERI; MUSSI; MOREIRA, 2009; VEIGA JUNIOR e PINTO, 2002).

Segundo a última edição do Index Kewensis (1996), o gênero Copaifera possui 72 espécies encontradas na natureza, sendo 16 delas exclusivas da flora brasileira. As copaibeiras, denominação popular, são encontradas nas Regiões Amazônica e Centro-oeste do Brasil. Entre as espécies mais abundantes, destacamse: C. officinalis L. (norte do Amazonas, Roraima, Colômbia, Venezuela e San Salvador), C. guianensis Desf. (Guianas), C. reticulata Ducke, C. multijuga Hayne (Amazônia), C. confertiflora Bth (Piauí), C. langsdorffii Desf. (Brasil, Argentina e Paraguai), C. coriacea Mart. (Bahia), C. cearensis Huber ex Ducke (Ceará) (VEIGA JUNIOR e PINTO, 2002).

O óleo de copaíba é encontrado em canais secretores localizados em todas as partes da árvore. Estes canais formam-se pela dilatação de espaços intercelulares (meatos) que se intercomunicam no meristema, chamados de canais esquizógenos. Os troncos das árvores destacam-se na secreção de óleo, pois é onde os canais longitudinais, distribuídos em faixas concêntricas, nas camadas de crescimento demarcadas pelo parênquima terminal, reúnem-se com um traçado irregular, em camadas lenhosas, muitas vezes sem se comunicarem. O óleo de copaíba, em termos biológicos, é um produto de excreção ou desintoxicação do organismo vegetal, e funciona como defesa da planta contra animais, fungos e bactérias (PIERI; MUSSI; MOREIRA, 2009; VEIGA JUNIOR e PINTO, 2002).

São vários os métodos relatados para a obtenção do óleo de copaíba. Antigamente, obtinha-se o óleo de formas bruscas que inutilizavam a árvore, sendo utilizada apenas para uma coleta. Atualmente, a coleta é feita através da incisão de dois furos no tronco da árvore com um trado de aproximadamente 2 metros de diâmetro. O primeiro furo é feito 1 metro acima da base da planta e o segundo aproximadamente 1,5 metro acima do primeiro. Um cano de PVC de $3 / 4$ de polegada é inserido nos orifícios e o óleo escoa. Terminada a coleta, o orifício é vedado com argila para impedir a infestação da árvore por fungos ou cupins, a argila pode ser retirada e novas coletas podem ser executadas no mesmo tronco, obtendo-se 
quantidade de óleo igual ou mesmo superior a primeira (PIERI; MUSSI; MOREIRA, 2009; VEIGA JUNIOR e PINTO, 2002).

A quantidade de óleo que uma árvore pode gerar é variável chegando até 40 litros por ano, porém nem todas as espécies são capazes de produzir tal quantidade. Em uma retirada há relatos de que a quantidade pode variar de 0,3 a 3 litros e até fornecer 30 litros em uma única coleta, dependendo da espécie e condições em que a árvore é submetida. Contudo, as características pertinentes ao solo, clima e espécie de Copaifera são fatores interferentes no aspecto e quantidade do óleo até sua atividade biológica propriamente dita (PIERI; MUSSI; MOREIRA, 2009; SANTOS et al., 2008; VEIGA JUNIOR e PINTO, 2002). Segundo Barbosa, Scudeller e Rosa (2009), a quantidade de óleo produzida no período chuvoso e seco foi diferente, sendo maior no período chuvoso. O óleo de copaíba apresenta-se como um líquido transparente, com viscosidade e coloração variável, cuja coloração encontra-se entre amarelo e marrom. Para a utilização farmacológica a literatura relata que os óleos mais escuros e viscosos apresentam maior eficácia (PIERI; MUSSI; MOREIRA, 2009; VEIGA JUNIOR e PINTO, 2002).

Em relação a composição, Schweitzer, em 1829, foi a primeira pessoa a relatar uma fração do óleo de copaíba que cristalizava após determinado período de repouso, a qual denominou ácido copaívico (VEIGA JUNIOR e PINTO, 2002). Desde então, novas substâncias e a correlação destas com a atividade biológica vem sendo descritas (LEANDRO et al., 2012). Atualmente, sabe-se que o óleo de copaíba consiste de uma parte sólida resinosa não volátil formada por ácidos diterpênicos, responsável por $55-60 \%$ do óleo diluída na outra parte, um óleo essencial composto de sesquiterpenos. Estes podem ser divididos em sesquiterpenos oxigenados (álcoois) e hidrocarbonetos sesquiterpênicos. A composição pode variar entre espécies e interespécies do gênero, fatores biológicos como insetos e fungos e abióticos (DIAS et al., 2014; LEANDRO et al., 2012; PIERI; MUSSI; MOREIRA, 2009; SANTOS et al., 2008; VEIGA JUNIOR e PINTO, 2002).

Os sesquiterpenos são os principais constituintes do óleo, chegando à $90 \%$ de sua composição. Por isso, muitos estudos têm atribuído sua atividade farmacológica a presença destes no óleo. Entretanto, o efeito farmacológico não pode ser atribuído a um único constituinte, pois os compostos presentes no óleo podem interagir sinergicamente para promover a atividade observada (LEANDRO et al., 2012). Os principais sesquiterpenos encontrados no óleo de copaíba são: $\beta$ - 
cariofileno, óxido de cariofileno, $\beta$-bisaboleno, $\alpha$-humuleno, $\alpha$ e $\beta$-selineno, $\alpha$ bisabolol, $\beta$-elemeno, $\delta$-cadineno, $\alpha$-cadinol, $\alpha$-cubebeno, $\alpha$-copaeno, e trans- $\alpha$ bergamoteno. Os diterpenos comumente encontrados são: ácido copálico, ácido polialtico, ácido hardwíckico, ácido caurenóico e ent-caurenóico junto com seus derivados (LEANDRO et al., 2012; PIERI; MUSSI; MOREIRA, 2009; VEIGA JUNIOR e PINTO, 2002).

$\mathrm{Na}$ medicina popular, principalmente no contexto histórico indígena, o óleo de copaíba era usado como cicatrizante de ferimentos cutâneos, antiinflamatório, antisséptico urinário, no tratamento de úlceras, bronquite e câncer (NOGUEIRA et al., 2012; VEIGA JUNIOR e PINTO, 2002). Atualmente, têm sido relatados diversos estudos comprobatórios de suas propriedades conhecidas na medicina popular. Dentre essas propriedades destaca-se atividade anti-inflamatória (GOMES et al., 2010; VEIGA et al., 2007), antitumoral (GOMES et al., 2008; LIMA et al., 2003), analgésica (GOMES et al., 2007), antifúngica (DEUS et al., 2011), antibacteriana (PIERI et al., 2011; MENDONÇA e ONOFRE, 2009; PIERI et al., 2010a; SANTOS et al., 2008; PACKER e LUZ, 2007; PACHECO; BARATA; DUARTE, 2006), além de ser amplamente usado na indústria de cosméticos (LEANDRO et al., 2012).

A partir disso, o óleo tem sido objeto de vários estudos na tentativa de provar ou adaptar o seu uso na terapêutica. Entre as várias pesquisas encontram-se os testes de sensibilidade dos microrganismos ao óleo de copaíba, uma vez que, o mesmo possui diferentes substâncias que podem atuar em diferentes células-alvo, agindo sinergicamente em várias estruturas e mecanismos da célula bacteriana, resultando em uma maneira de prevenir ou impedir a emergente resistência (PIERI et al., 2011; MENDONÇA e ONOFRE, 2009; PIERI et al., 2009; SANTOS et al., 2008; PACKER e LUZ, 2007; PACHECO; BARATA; DUARTE, 2006).

\subsubsection{Atividade antimicrobiana do óleo de copaíba}

A atividade antimicrobiana do óleo de copaíba é uma das propriedades mais frequentemente estudadas. Em um estudo feito por Santos et al. (2008), avaliou-se a atividade antimicrobiana de três espécies de árvores: Copaifera martii, C. officinalis e $C$. reticulada frente às bactérias Gram-positivas e Gram-negativas. Os 
autores observaram a inibição apenas das bactérias Gram-positivas: $S$. aureus, $S$. aureus resistente a meticilina, $S$. epidermidis, B. subtilis e $E$. faecalis com uma concentração inibitória mínima (CIM) variando entre 31,3-62,5 $\mu \mathrm{g} \mathrm{mL}^{-1}$.

Segundo Santos et al. (2008) através de análise por microscopia eletrônica de varredura, o tratamento da bactéria $S$. aureus com óleo resina de $C$. martii revelou a lise das bactérias, provocando aglomeração celular. A microscopia mostrou ainda, perturbações e danos a parede celular, resultando no extravasamento citoplasmático, alterações morfológicas e um decréscimo no volume celular, indicando que o óleo de copaíba pode afetar a parede celular. Tal fato, sugere um hipotético mecanismo de ação para o óleo de copaíba, podendo pressupor que a diferença estrutural entre bactérias Gram-positivas e Gramnegativas é a causa da não inibição de bactérias Gram-negativas. A parede celular das bactérias Gram-positivas consiste de camadas expressivas de peptideoglicano, formando uma estrutura espessa e rígida, associadas a ácidos teicóicos. Já, a parede celular das bactérias Gram-negativas compõe-se de uma membrana externa rica em lipopolissacarídeos, lipoproteínas e fosfolipídeos localizada acima de uma fina camada de peptideoglicano (TORTORA; FUNKE; CASE, 2012).

Masson et al. (2013) relataram valores de CIM e CBM para Copaifera langsdorffi de $200 \mu \mathrm{g} \mathrm{mL}^{-1}$ para $S$. aureus (ATCC 6538) e, também não observaram a inibição de bactérias Gram-negativas.

Entretanto, Mendonça e Onofre (2009) mostraram a atividade antimicrobiana do óleo resina de $C$. multijuga contra as bactérias Gram-negativas $E$. coli e $P$. aeruginosa, utilizando uma técnica qualitativa (Método de disco difusão). Pacheco; Barata; Duarte (2006), por sua vez, revelaram a inatividade do mesmo óleo utilizado por Mendonça e Onofre (2009) em todas as bactérias Gram-negativas estudadas.

Essa divergência nos resultados encontrados nos estudos está relacionada com as diferentes espécies do gênero Copaifera, que apresentam variações nas características físico-químicas, bem como na constituição química dos óleos. Entre os sesquiterpenos com atividade antimicrobiana reconhecida estão o $\beta$ cariofileno (GOREN et al., 2011) e o $\delta$-cadineno (PÉREZ-LÓPEZ et al., 2011; KUBO; MUROI; HIMEJIMA, 1992). 
Goren et al. (2011) observaram a atividade antimicrobiana do $\beta$-cariofileno contra E. coli, S. aureus, $K$. pneumoniae e $P$. aeruginosa frente a levedura $C$. albicans.

Kubo, Muroi e Himejima (1992) observaram a atividade do $\delta$-cadineno na inibição do crescimento de Streptococcus mutans, importante bactéria causadora de cárie dental e Propionibacterium acnes, uma das bactérias responsáveis pela acne. Pérez-López et al. (2011) também isolaram como principal composto ativo, o $\delta$-cadineno, presente no óleo obtido da fruta de Schinus molle, e relataram uma CIM de $31,25 \mu \mathrm{g} \mathrm{mL}^{-1}$ frente a $S$. pneumoniae, bactéria resistente aos antibióticos convencionais.

Entre os diterpenos com atividade antimicrobiana reconhecida, está o ácido copálico, mostrando atividade satisfatória contra $B$. subtilis, $S$. aureus e $S$. epidermidis (TINCUSI et al., 2002). Recentemente, Souza et al. (2011) analisaram quatro diterpenos e notaram que o ácido copálico foi o mais eficiente deles na inibição de Porphyromonas gengivalis (CIM de $3,1 \mu \mathrm{g} \mathrm{mL} \mathrm{m}^{-1}$ ). Em outro estudo feito com bactérias cariogênicas, os autores observaram que o ácido copálico foi ativo contra a maioria dos microrganismos causadores de cárie (SOUZA et al., 2011).

Outro diteperno comumente encontrado no óleo de copaíba é o ácido hardwíckico e mostrou-se eficiente na atividade antibacteriana qualitativa sobre as linhagens $B$. subtilis, $S$. aureus e Mycobacterium smegmatis (MCCHESNEYA; CLARK; SILVEIRA, 1991). Estudos com metodologia quantitativa também evidenciaram a atividade antimicrobiana desse ácido (KUETE et al., 2007). Recentemente, Kuete et al. (2011) relataram a ineficácia desse diterpeno no contexto de bactérias super-resistentes.

O ácido caurenóico, apesar da similaridade com o ácido copálico e por muitas vezes ser indistinguível deste nas técnicas de detecção, também apresenta atividade antimicrobiana. Tincusi et al. (2002) isolaram o ácido do óleo resina de $C$. paupera e mostraram a inibição de B. subtilis, $S$. aureus e $S$. epidermidis. A Figura 8 representa a estrutura química dos principais sesquiterpenos e diterpenos que conferem atividade antimicrobiana ao óleo de copaíba.

As variações na composição dos óleos e os fatores inerentes ao solo, sazonalidade, cultivo, extração e armazenamento, em que ocorre a mistura dos óleos entre diferentes copaibeiras sem a preocupação botânica e até a mistura com outros óleos de coloração e odor similares (PIERI; MUSSI; MOREIRA, 2009; 
SANTOS et al., 2008; VEIGA JUNIOR e PINTO, 2002) são limitações que ainda devem ser compiladas na tentativa de padronizar e tornar reprodutível a utilização farmacológica de determinada espécie. Esses interferentes podem mudar a composição química e consequentemente a atividade biológica do óleo. Além disso, a genética bacteriana deve ser levada em consideração e o entendimento da interação bactéria-antimicrobiano pode sanar dúvidas na maneira como o efeito antibacteriano desencadeia-se e no desenvolvimento de resistência.

Figura 8 - Estrutura química dos principais sesquiterpenos e diterpenos com atividade antimicrobiana encontrados no óleo de copaíba.

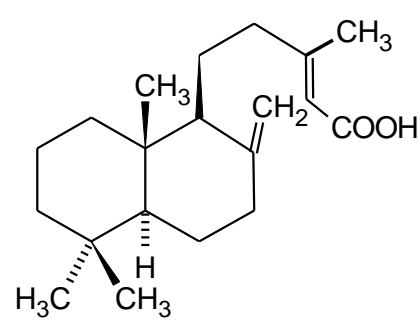

ácido copálico

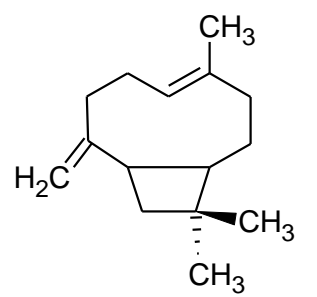

$\beta$-cariofileno

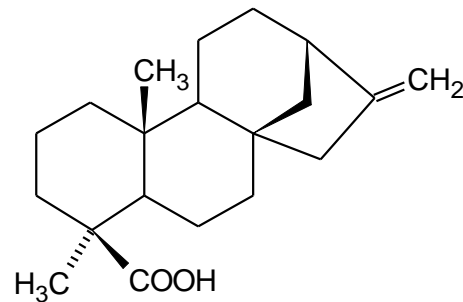

ácido caurenóico<smiles>CC1=C[C@H]2C(=C(C)CC[C@@H]2C(C)C)CC1</smiles>

$\delta$-cadineno

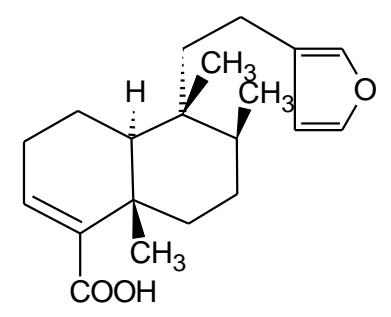

ácido hardwickiico

Fonte: Autoria própria.

Há na literatura dois trabalhos utilizando quitosana e óleo de copaíba. Lucca (2013) estudou a incorporação do óleo de copaíba em hidrogéis, sendo um deles formado por quitosana, para avaliar o perfil de permeação cutânea no modelo de pele de orelha suína. Devido à instabilidade mostrada pelo hidrogel de quitosana, utilizou-se Carbopol $980 \AA$ como agente gelificante para dar continuidade ao estudo. Em outro estudo descrito por Santos (2014) foi utilizado quitosana na preparação de filmes incorporados com óleos essenciais, entre eles o óleo de copaíba, como conservante no revestimento de filés de tilápia.

Contudo, não foi descrito até o presente momento, nenhum estudo associado à atividade antimicrobiana de emulsões de quitosana/gelatina/óleo de 
Revisão Bibliográfica

copaíba, principalmente utilizando-se a quitosana derivada de $\beta$-quitina, demostrando o potencial inovador do trabalho. 


\section{MATERIAIS E MÉTODOS}

\subsection{Obtenção da quitosana}

A quitosana foi obtida a partir de gládios de lula (Loligo sp.) cedidos por Miami Comércio e Exportação de Pescados Ltda. (Cananéia - SP) através de três etapas básicas: desmineralização, desproteinização e desacetilação (HORN; MARTINS; PLEPIS, 2009).

Primeiramente, os gládios de lula foram lavados para eliminar resíduos, secos, triturados e separados com peneira obtendo-se partículas com diâmetro menor que $0,25 \mathrm{~mm}$. Para garantir maior eficiência, cada etapa do procedimento foi repetida duas vezes.

No processo de desmineralização, para isolar a $\beta$-quitina foi utilizado 40,0 g de gládio moído e adicionou-se solução de $\mathrm{HCl}$ 0,55 $\mathrm{mol} \mathrm{L}^{-1}$ na razão $(1 \mathrm{~g}$ de gládio/15 $\mathrm{mL}$ de $\mathrm{HCl}$ ) sob agitação constante por $2 \mathrm{~h}$ à temperatura ambiente. Em seguida, a solução foi lavada com água deionizada com agitação constante, até que se alcançasse a neutralidade e o sólido obtido foi seco em estufa a $40{ }^{\circ} \mathrm{C}$.

A desproteinização foi feita pela adição de uma solução de $\mathrm{NaOH}$ $0,3 \mathrm{~mol} \mathrm{~L}^{-1}$ na proporção (1 $\mathrm{g}$ de gládio de lula desmineralizado/10 $\mathrm{mL}$ de $\mathrm{NaOH}$ ) com agitação e temperatura controlada a $80 \stackrel{\circ}{\mathrm{C}}$ por 1 h. Como descrito anteriormente, o sólido obtido foi lavado até a neutralidade e o material foi seco em estufa a $40 \stackrel{\circ}{\mathrm{C}}$.

Para obter-se a quitosana a partir da $\beta$-quitina foi feito um tratamento alcalino utilizando-se uma solução de $\mathrm{NaOH} 40 \%$ (massa/massa) na proporção $\beta$ quitina/solução de $1 \mathrm{~g} / 20 \mathrm{~mL}$. O sistema foi mantido à temperatura de $80{ }^{\circ} \mathrm{C} \mathrm{com}$ agitação constante por $3 \mathrm{~h}$ e em atmosfera de $\mathrm{N}_{2}$ e, novamente o material obtido foi lavado até a neutralidade e seco em estufa a $40{ }^{\circ} \mathrm{C}$.

A partir da quitosana obtida na última etapa foi preparado um gel de quitosana $2 \%$ por dissolução em ácido acético $1 \%$. 


\subsection{Caracterização da quitosana}

\subsubsection{Determinação do grau médio de acetilação por titulação condutimétrica}

O grau de acetilação da quitosana foi determinado por titulação condutimétrica conforme descrito por TORRES et al., 2005. A amostra de quitosana (250 mg), previamente seca em estufa a $60^{\circ} \mathrm{C}$, foi solubilizada em $50 \mathrm{~mL}$ de $\mathrm{HCl} 0,05 \mathrm{~mol} \mathrm{~L}^{-1}$ e mantida sob agitação por $18 \mathrm{~h}$. Essa solução foi diluída para $250 \mathrm{~mL}$ com água deionizada. Alíquotas de $50 \mathrm{~mL}$ da solução resultante foram tituladas com uma solução de $\mathrm{NaOH} 0,0797 \mathrm{~mol} \mathrm{~L}^{-1}$ previamente padronizada com ácido oxálico $0,05 \mathrm{~mol} \mathrm{~L}^{-1}$. As variações de condutância durante a titulação foram medidas através do condutivímetro Gehaka, modelo CG-2000. As titulações foram feitas em triplicata e a $25^{\circ} \mathrm{C}$.

\subsubsection{Determinação da massa molar média por viscosimetria}

A massa molar média da quitosana foi determinada por viscosimetria (WITT et al., 2010; RINAUDO, 2006). Uma solução padrão de quitosana foi preparada com $20 \mathrm{mg}$ de quitosana, previamente seca $\left(\mathrm{T}=40{ }^{\circ} \mathrm{C}\right)$ em $25 \mathrm{~mL}$ de solução de ácido acético $0,6 \mathrm{~mol} \mathrm{~L}^{-1}$ sob agitação constante por $24 \mathrm{~h}$. Em seguida, adicionou-se $25 \mathrm{~mL}$ de acetato de sódio $0,4 \mathrm{~mol} \mathrm{~L}^{-1}$ e a solução resultante, denominada de solução estoque, foi mantida em agitação constante por mais $24 \mathrm{~h}$.

Um tampão de ácido acético $0,3 \mathrm{~mol} \mathrm{~L}^{-1} /$ acetato de sódio $0,2 \mathrm{~mol} \mathrm{~L}^{-1} \mathrm{a}$ $\mathrm{pH}$ 4,5 foi preparado para ser empregado como branco e para as sucessivas diluições da solução estoque, de modo a assegurar que a força iônica das soluções fosse mantida. As concentrações das amostras de quitosana variaram de 1,5 a $4,0 \times 10^{-4} \mathrm{~g} \mathrm{~mL}^{-1}$.

Alíquotas de aproximadamente $5 \mathrm{~mL}$ da solução tampão ou das soluções de quitosana foram transferidas para um viscosímetro capilar tipo Ubbelohde a $25 \stackrel{\circ}{ } \mathrm{C}$. As medidas de tempo de escoamento da viscosidade específica $\left(\eta_{\mathrm{sp}}\right)$ 
correspondem à média de dez determinações. Utilizando-se as médias obtidas, a viscosidade específica de cada solução foi determinada através da equação 1 :

$$
\eta_{s p}=\frac{t-t_{0}}{t_{0}}
$$

sendo, $\eta_{\mathrm{sp}}$ viscosidade específica; $\mathrm{t}$ tempo médio de escoamento da amostra e $t_{0}$ tempo médio de escoamento do solvente.

Para obter a massa molar da quitosana, além da viscosidade específica, é necessário a determinação da viscosidade reduzida e da viscosidade intrínseca. $A$ viscosidade reduzida é dada por meio da equação 2 :

$$
\eta_{\text {red }}=\frac{\eta_{s p}}{C}
$$

na qual, $\eta_{\text {red }}$ é a viscosidade reduzida $\left(\mathrm{mL} \mathrm{g}^{-1}\right), \eta_{\mathrm{sp}}$ é a viscosidade específica e $C$ a concentração da solução $\left(\mathrm{g} \mathrm{mL}^{-1}\right)$.

Já, a viscosidade intrínseca é determinada pela extrapolação da diluição infinita da curva de viscosidade reduzida versus a concentração da solução. A viscosidade assim determinada satisfaz a relação de Mark-Houwink (equação 3) e assim, pode-se calcular a massa molar média viscosimétrica da quitosana.

$$
[\eta]=k M^{\alpha}
$$

sendo [ $\eta$ ] a viscosidade intrínseca, $\mathrm{M}$ a massa molecular média, $\mathrm{k}$ e $\alpha$ as constantes empíricas que dependem da natureza do polímero, do solvente e da temperatura. Os valores dos parâmetros $\mathrm{k}$ e $\alpha$ utilizados foram 0,074 e 0,80, respectivamente, concordantemente com o grau de acetilação da quitosana pré-estabelecido (WITT et al., 2010; RINAUDO, 2006).

\subsection{Obtenção do gel de gelatina}

O gel de gelatina $2 \%$ foi preparado por dissolução de $2,0 \mathrm{~g}$ de gelatina comercial (Sigma®, Tipo A) em $98 \mathrm{~mL}$ de água, sendo gelatinizada a $60^{\circ} \mathrm{C}$ durante 30 min, seguido por resfriamento. 


\section{4 Óleos de copaíba}

Foram utilizados neste trabalho 3 óleos de copaíba (OC), sendo um advindo de São Paulo (SP) e os outros adquiridos no mercado municipal de Belém (PA). O primeiro foi nomeado de acordo com a origem em OC(S) e os outros óleos obtidos em Belém foram denominados $\mathrm{OC}(\mathrm{C})$ e $\mathrm{OC}(\mathrm{E})$ por apresentarem coloração clara e escura, respectivamente como mostra a Figura 9.

Figura 9 - Fotografia digital dos óleos de copaíba: (A) OC(S), (B) OC(C) e (C) OC(E).

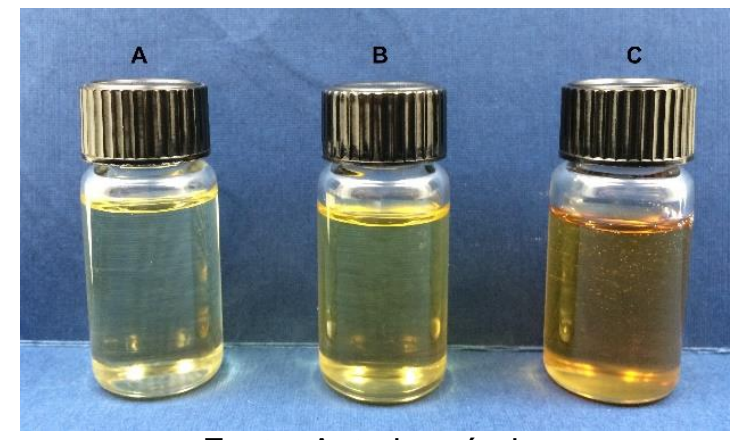

Fonte: Autoria própria.

\subsection{Preparo das amostras}

O gel de quitosana/gelatina foi obtido a partir da mistura dos géis de quitosana e gelatina na proporção 2:1 sob agitação mecânica constante (2.000 rpm) durante 30 min.

A mistura final dos géis foi dividida em duas frações. Na primeira fração o $\mathrm{pH}$ foi ajustado para 5,0 com solução de bicarbonato de sódio $0,5 \mathrm{~mol} \mathrm{~L}^{-1}$ denominando-se este gel QG. Com a segunda fração do gel e os óleos de copaíba foram preparadas emulsões (Figura 10). Para isso, os óleos de copaíba foram solubilizados em dimetilsulfóxido (DMSO) para que ao ser adicionado em meio de cultura caldo Müeller Hinton (caldo MH) o solvente DMSO estivesse a 1\% e os óleos nas concentrações de $8000 \mu \mathrm{g} \mathrm{mL}^{-1}$ quando OC(S), $2000 \mu \mathrm{g} \mathrm{mL}^{-1}$ quando OC(C) e $250 \mu \mathrm{g} \mathrm{mL}^{-1}$ quando $\mathrm{OC}(\mathrm{E})$. Em seguida, cada solução de $\mathrm{OC}$ em DMSO foi adicionada à $125 \mathrm{\mu g} \mathrm{mL}^{-1}$ de quitosana sob agitação mecânica constante a $2000 \mathrm{rpm}$ durante $30 \mathrm{~min}$. As emulsões foram nomeadas de acordo com o tipo de óleo utilizado em $\mathrm{QGOC}(\mathrm{S}), \mathrm{QGOC}(\mathrm{C})$ e $\mathrm{QGOC}(\mathrm{E})$, respectivamente. As emulsões não 
necessitaram do ajuste do $\mathrm{pH}$, uma vez que, o DMSO possui pKa 35 e elevou o $\mathrm{pH}$ para 5,5, 5,8 e 6,5, respectivamente. As concentrações das emulsões foram determinadas a partir da concentração inibitória mínima (CIM) do gel de quitosana/gelatina e dos óleos de copaíba através dos testes de atividade antimicrobiana, obtendo-se emulsões através da mistura da CIM de cada óleo de copaíba com a CIM do gel QG. Essa mistura foi calculada para concentrações de 4x > CIM para as bactérias Staphylococcus aureus e Pseudomonas aeruginosa e 2x > CIM para a bactéria Escherichia coli.

Figura 10 - Fotografia digital das amostras: (A) OC(S), (B) QG e (C) QGOC(S).

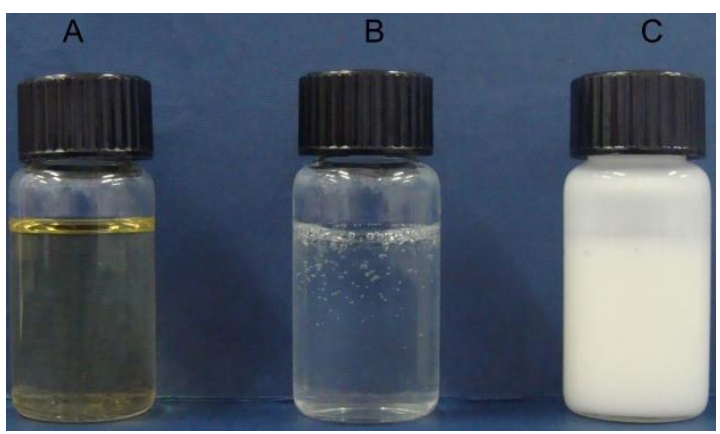

Fonte: Autoria própria.

As amostras foram analisadas por espectroscopia na região do infravermelho (FTIR). Para obtenção dos espectros foram preparados filmes a partir do gel QG e das emulsões QGOC (S), (C) e (E) em fôrmas de teflon®, secos sob fluxo de ar, a temperatura ambiente (Método de Casting). Após a secagem, estes foram colocados em dessecador na presença de $\mathrm{NaOH}$ sólido para retirada de água residual. As medidas dos óleos de copaíba (em placa de silício) e dos filmes foram feitas em um Espectrofotômetro Shimadzu IRAffinity-1, com 32 scans, no intervalo de $400-4000 \mathrm{~cm}^{-1}$ e resolução de $4 \mathrm{~cm}^{-1}$.

\subsubsection{Análise macroscópica e microscópica das emulsões}

Após $24 \mathrm{~h}$ do preparo das emulsões e durante todos os ensaios, observou-se as características organolépticas e a homogeneidade das formulações para identificar presença de sedimentação, coalescência e alterações de cor (FERRARI, 1998). 
Para confirmar a obtenção satisfatória de emulsões, pequena quantidade das amostras foi colocada em lâmina de vidro e submetida à análise microscópica (Microscópio óptico Primo Star) visando observar características morfológicas das formulações, como homogeneidade e a presença de gotículas de óleo. As imagens foram obtidas através de câmera digital acoplada ao microscópio com aumento de 10x (FERRARI, 1998).

\subsubsection{Testes de estabilidade das emulsões}

\subsubsection{Teste de centrifugação}

Em um tubo de ensaio cônico graduado para centrífuga (Fanem $\AA$, modelo 205) foram adicionados $5,0 \mathrm{~g}$ de cada amostra e submetidas aos ciclos de 1000, 1500, 2500, 3000 e 3500 rpm durante 15 minutos em cada rotação à temperatura ambiente $\left(25^{\circ} \mathrm{C}\right)$ para averiguar a estabilidade das formulações, uma vez que, esse teste é de caráter eliminatório, onde utiliza-se a força centrífuga para acelerar a sedimentação, cremeação ou a coalescência do sistema, demonstrando rapidamente possíveis processos de instabilidade (ANVISA, 2004; FERRARI, 1998; RIEGER, 1996).

\subsubsection{Estresse térmico}

As emulsões foram acondicionadas em frascos de vidro transparentes fechados e submetidas ao aquecimento em banho maria sob agitação magnética constante com variação de temperatura de $45 \pm 2$ a $70 \pm 2{ }^{\circ} \mathrm{C}$. O aumento de temperatura ocorreu de $10 \mathrm{em} 10^{\circ} \mathrm{C}$, mantendo-se por 30 min em cada temperatura. Após o término de cada ciclo e após o resfriamento natural das amostras até a temperatura ambiente, avaliou-se macroscopicamente a estabilidade das emulsões (BRACONI et al., 1995). Esse teste emprega a temperatura como condição de estresse sobre a formulação possibilitando a observação de alterações que poderão 
ocorrer em função de mudanças de temperatura durante o armazenamento ou transporte do produto.

Durante o período de execução dos ensaios microbiológicos (aproximadamente 5 meses), as amostras foram submetidas ocasionalmente a diferentes temperaturas:

- Temperatura ambiente $(25 \pm 2 \stackrel{\circ}{\circ})$;

- Temperatura de armazenamento em geladeira $(4 \pm 2 \stackrel{\circ}{ } \mathrm{C})$;

- Estufa de secagem e esterilização (Fanem®, Modelo 315 SE) a $45 \pm 2 \stackrel{\circ}{ } \mathrm{C}$.

Esses testes visam acelerar interações físico-químicas entre as matériasprimas num reduzido espaço de tempo (RIEGER, 1996). A temperatura elevada acelera reações físico-químicas e químicas, podendo alterar a atividade de componentes, viscosidade, aspecto, cor e odor do produto. Baixas temperaturas aceleram possíveis alterações físicas como turvação, precipitação, cristalização. A não-conformidade no processo de fabricação, armazenamento ou transporte também podem levar a alterações nas características dos produtos (ANVISA, 2004).

\subsubsection{Determinação dos valores de $\mathrm{pH}$}

$\mathrm{O}$ pH das emulsões foi determinado após $24 \mathrm{~h}$ de preparo e após os testes de estabilidade inserindo-se o eletrodo (pHmetro Qualxtron - Modelo 8010) diretamente nas amostras com auxílio de agitação mecânica para homogeneização a $25 \stackrel{\circ}{\circ}$ (FERRARI, 1998). A variação de $\mathrm{pH}$ em um determinado intervalo de tempo e sobre condições ambientais a que o produto possa ser submetido também é um parâmetro importante que fornece indicações da estabilidade.

\subsection{Obtenção das linhagens bacterianas}

As linhagens bacterianas foram obtidas de uma coleção de culturas padrão (ATCC - American Type Culture Collection) fornecidas pelo Laboratório de Referência do Instituto Oswaldo Cruz (INCQS - FIOCRUZ). As bactérias empregadas como modelo foram Staphylococcus aureus (ATCC 25923), Escherichia 
coli (ATCC 25922) e Pseudomonas aeruginosa (ATCC 27853), uma vez que são os tipos mais comuns encontrados na clínica médica associados a infecções de pele e hospitalares.

As linhagens foram mantidas em caldo extrato de levedura triptona de soja (TSYEB) para $S$. aureus e $E$. coli e, em caldo nutriente para $P$. aeruginosa acrescidos de $20 \%$ de glicerol e armazenadas em freezer a $-20 \stackrel{\circ}{\circ}$. Os ensaios de atividade antimicrobiana foram feitos a partir das culturas estoque armazenadas a $-20 \stackrel{\circ}{ } \mathrm{C}$.

\subsection{Padronização do inóculo}

As linhagens de $S$. aureus e $E$. coli foram semeadas em placas de ágar extrato de levedura triptona de soja (TSYEA) e a linhagem de $P$. aeruginosa foi inoculada em ágar nutriente a partir do estoque a $-20 \stackrel{\circ}{\mathrm{C}}$ e incubadas por $24 \mathrm{~h}$ a $37 \stackrel{\circ}{ }$ C. Esse procedimento foi repetido por mais uma vez para verificação da viabilidade e pureza das linhagens. Para determinação da atividade antimicrobiana foram preparadas suspensões em solução salina esterilizada ( $\mathrm{NaCl}$ 0,86\%), utilizando como padrão a escala 0,5 de McFarland $(0,5 \mathrm{~mL}$ de cloreto de bário $\left(\mathrm{BaCl}_{2}\right)$ a $1 \%+99,5 \mathrm{~mL}$ de ácido sulfúrico $\left(\mathrm{H}_{2} \mathrm{SO}_{4}\right)$ a $1 \%$, que corresponde a aproximadamente $1,5 \times 10^{8}$ UFC $\mathrm{mL}^{-1}$ (Unidade Formadora de Colônias por $\mathrm{mL}$ ) (CLSI, 2005). Com o auxílio de uma alça esterilizada, algumas colônias isoladas das culturas de 24 horas foram selecionadas e suspensas em $5 \mathrm{~mL}$ de solução salina estéril e a turbidez das suspensões foi medida em $610 \mathrm{~nm}$ em espectrofotômetro UV-Vis (Thermo Scientific, Genesys 10 UV), de modo a obter densidade óptica entre 0,09 a 0,13 .

Após o ajuste das suspensões ao padrão 0,5 de McFarland, estas foram diluídas 1:10 em solução salina para obter-se uma concentração de $10^{7}$ UFC mL ${ }^{-1}$ (CLSI, 2005). 


\subsection{Influência do pH no crescimento bacteriano}

Como a quitosana pode precipitar em pH superiores a 6,0 foi feito um controle de crescimento bacteriano (JUMAA; FURKERT; MÜLLER, 2002). O meio de cultura caldo Müeller Hinton (meio de escolha padrão para teste de sensibilidade a antibióticos) foi ajustado com solução de ácido lático 1\% nos valores de pH 5,0 e 5,5 . O crescimento das bactérias nos meios com diferentes $\mathrm{pH}$ foi comparado com o meio padrão ( $\mathrm{pH} 7,4)$ após inoculação de cada suspensão bacteriana padronizada segundo a escala 0,5 de McFarland. A avaliação do crescimento bacteriano nos meios nos diferentes $\mathrm{pH}$ foi feita após $24 \mathrm{~h}$ de incubação a $37{ }^{\circ} \mathrm{C}$ através da leitura da absorbância em $610 \mathrm{~nm}$ em espectrofotômetro, como mencionado anteriormente.

\subsection{Teste de atividade antimicrobiana}

Os ensaios para determinação da concentração inibitória mínima (CIM) dos óleos, do gel QG e das emulsões QGOC frente às linhagens de $S$. aureus, $E$. coli e $P$. aeruginosa foram feitos utilizando-se a técnica de microdiluição em caldo segundo metodologia estabelecida pelo Clinical and Laboratory Standards Institute, CLSI M7-A6 2005, como mostrado no esquema da Figura 11. Também foram feitos testes para determinação da concentração bactericida mínima (CBM).

Os ensaios de atividade antimicrobiana foram feitos em octoplicata e com no mínimo três repetições independentes. Todos os testes foram comparados com os controles positivos de crescimento (cultura inoculada sem tratamento) assim como com os controles negativos (meio sem inóculo). A atividade antimicrobiana foi avaliada através da CIM e da CBM para cada linhagem bacteriana e antimicrobiano testado. Os resultados foram expressos como a moda (definida estatisticamente como a observação de maior frequência) de pelo menos três repetições independentes. 
Figura 11 - Esquema representativo do procedimento experimental para os testes de atividade antimicrobiana.

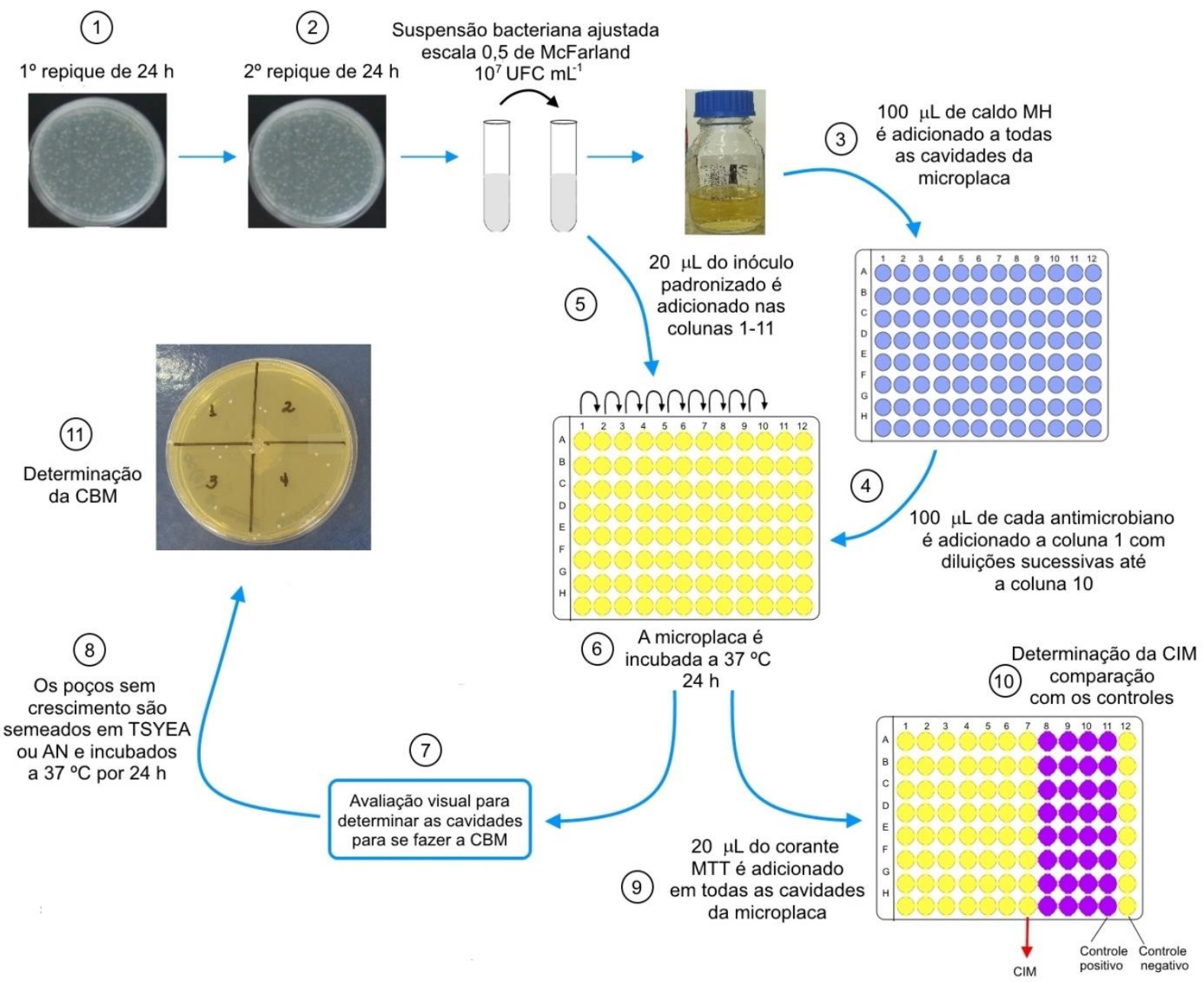

Fonte: Autoria própria.

\subsubsection{Preparo das soluções estoque para uso nos testes de atividade antimicrobiana}

\subsubsection{1 Óleos de copaíba}

As soluções estoque dos óleos de copaíba OC(S), OC(C) e OC(E) foram preparadas, inicialmente na concentração de $8000 \mu \mathrm{g} \mathrm{mL}^{-1}$. Para isso, os óleos foram pesados e solubilizados em DMSO. Após solubilização, as soluções foram filtradas em filtro 0,22 $\mu \mathrm{m}$ para garantir a esterilidade. Em seguida, quantidade suficiente das soluções de óleo em DMSO foram adicionadas ao meio de cultura caldo Müeller Hinton para obter a concentração de $8000 \mu \mathrm{g} \mathrm{mL}^{-1}$ e para que a 
concentração do solvente DMSO fosse $1 \%$ no meio. Cada solução estoque foi distribuída em placas de microdiluição de 96 cavidades com diluições sucessivas $(2 X)$.

\subsubsection{Gel de quitosana/gelatina}

Do mesmo modo que as soluções de óleo de copaíba, foi preparada uma solução estoque a partir do gel QG em meio de cultura caldo Müeller Hinton pH 5,5 em concentração inicial de $4000 \mu \mathrm{g} \mathrm{mL}^{-1}$ levando-se em consideração a concentração da quitosana no gel QG. A solução foi filtrada em filtro $0,45 \mu \mathrm{m}$ e distribuída nas placas de microdiluição de 96 cavidades em diluições sucessivas (2X).

\subsubsection{Emulsões de quitosana/gelatina/óleo de copaíba}

Para determinar o efeito da interação antimicrobiana dos óleos de copaíba com o gel QG foram preparadas soluções estoque a partir das emulsões QGOC(S), QGOC(C) e QGOC(E) em meio de cultura caldo Müeller Hinton pH 5,5. Para se obter concentrações correspondentes à $2 x>C I M, C I M, 1 / 2 \mathrm{CIM}$ e assim sucessivamente quando diluídas no meio, as emulsões utilizadas no preparo das soluções estoque foram formuladas em concentrações $4 x>$ CIM para as bactérias Staphylococcus aureus e Pseudomonas aeruginosa e $2 \mathrm{x}>\mathrm{CIM}$ para a bactéria Escherichia coli conforme item 5.5. As soluções foram filtradas em filtro $0,45 \mu \mathrm{m} e$ distribuídas nas placas de microdiluição de 96 cavidades em diluições sucessivas (2X).

\subsubsection{Determinação da CIM dos óleos de copaíba e do gel de quitosana/gelatina}

Todas as cavidades da placa de microdiluição de 96 poços foram primeiramente preenchidas com $100 \mu \mathrm{L}$ de caldo de cultivo Müeller Hinton pH 5,5. 
Em seguida, $100 \mu \mathrm{L}$ de cada amostra contendo a solução estoque de óleo de copaíba em DMSO 1\% foram adicionados nas 8 cavidades da primeira coluna (1) da placa (Figura 11). A diluição da solução de óleo de copaíba $\left(8000 \mu \mathrm{g} \mathrm{mL}^{-1}\right) \mathrm{com}$ o meio de cultura na primeira coluna resultou na primeira concentração estabelecida de $4000 \mu \mathrm{g} \mathrm{mL}^{-1}$. Após homogeneização com micropipeta, $100 \mu \mathrm{L}$ da coluna 1 foram transferidos para a coluna 2 resultando em uma concentração de $2000 \mu \mathrm{g} \mathrm{m}^{-1}$, e assim sucessivamente até a coluna 10 . A coluna 11 foi utilizada como controle positivo de crescimento contendo o caldo de cultura e o inóculo bacteriano (A-D) e preenchida com o caldo de cultura, o inóculo bacteriano e DMSO 1\% $(\mathrm{E}-\mathrm{H})$, para confirmação do crescimento bacteriano em pH 5,5 e na presença do solvente DMSO a $1 \%$.

A coluna 12 foi utilizada como controle negativo contendo de A-D apenas o caldo Müeller Hinton e de E-H o caldo de cultura e cada solução de óleo de copaíba em DMSO na primeira concentração $\left(4000 \mu \mathrm{g} \mathrm{mL}^{-1}\right)$ para comprovação da esterilidade do meio de cultura e das soluções de óleo de copaíba.

A todas as cavidades, exceto à coluna 12, foram adicionados $20 \mu \mathrm{L}$ de inóculo de cada linhagem bacteriana padronizado na concentração $10^{7} \mathrm{UFC} \mathrm{mL}{ }^{-1}$. A placa de microdiluição foi fechada e incubada a $37^{\circ} \mathrm{C}$ por 24 horas.

Após o período de incubação foi feita uma avaliação visual do crescimento microbiano e nas cavidades em que não foi constatado o crescimento foram feitos testes para determinar a concentração bactericida mínima (CBM) conforme item 5.9.4. Para confirmação da CIM observada na avaliação visual foram adicionados $20 \mu \mathrm{L}$ do corante brometo de tetrazolium (MTT - $1 \mathrm{mg} \mathrm{mL}^{-1}$ ) em todas as cavidades das placas. Esse corante indica a atividade metabólica bacteriana quando ocorre mudança de cor do amarelo para o roxo. Isso ocorre devido a presença de enzimas desidrogenases na membrana citoplasmática que reduzem o sal de MTT formando cristais de formazan de coloração roxa. A CIM foi determinada como a menor concentração de agente antimicrobiano que inibe completamente o crescimento das bactérias em relação ao controle positivo. Cada bactéria foi testada com cada solução de óleo de copaíba em DMSO 1\% em microplacas separadas e os ensaios foram feitos com no mínimo três repetições independentes.

A CIM do gel QG foi determinada como exposto acima e como mostrado na Figura 11. 


\subsubsection{Determinação da interação antimicrobiana nas emulsões}

Inicialmente, foi determinada a CIM dos óleos de copaíba e do gel QG sobre as linhagens bacterianas em teste isolado, seguindo a metodologia descrita na subseção 5.9.2.

Em seguida foram preparadas combinações dos óleos de copaíba OC(S), $\mathrm{OC}(\mathrm{C})$ e $\mathrm{OC}(\mathrm{E})$ com o gel de quitosana/gelatina (QG) nas concentrações de $4 \mathrm{x}>\mathrm{CIM}$ e $2 \mathrm{x}>\mathrm{CIM}$ a partir dos valores obtidos no teste isolado, resultando nas emulsões $\mathrm{QGOC}(\mathrm{S}), \mathrm{QGOC}(\mathrm{C})$ e $\mathrm{QGOC}(\mathrm{E})$ conforme item 5.5. Após o processo de emulsificação, determinou-se as menores concentrações de cada combinação em que houve inibição do crescimento bacteriano.

Para isso, seguiu-se a metodologia descrita na sessão 5.9 .2 e representada na Figura 11.

\subsubsection{Determinação da CBM}

A partir das concentrações dos óleos de copaíba, do gel $Q G$ e das emulsões $\mathrm{QGOC}(\mathrm{S}), \mathrm{QGOC}(\mathrm{C})$ e $\mathrm{QGOC}(\mathrm{E})$ que não apresentaram crescimento visual no teste de CIM foi possível analisar a concentração bactericida mínima (CBM). Com auxílio de uma alça de inoculação esterilizada, transferiu-se uma alíquota do meio das cavidades em que não houve crescimento visual microbiano para placas de TSYEA para as linhagens de $S$. aureus e E. coli e para placas de ágar nutriente quando $P$. aeruginosa e incubou-se a $37^{\circ} \mathrm{C}$ por $24 \mathrm{~h}$.

A menor concentração que não apresentou crescimento microbiano nas placas foi designada como a CBM. Nos casos em que todas as concentrações testadas apresentaram crescimento bacteriano concluiu-se que o efeito dos antimicrobianos foi bacteriostático para a linhagem testada. 


\subsection{Curva de sobrevivência}

Para avaliar o crescimento bacteriano em função do tempo na presença da emulsão foram construídas curvas de sobrevivência bacteriana comparando-se o comportamento em relação ao controle positivo (cultura sem tratamento) (VERMA, 2007).

\subsubsection{Preparo das soluções estoque}

Para as curvas utilizando a emulsão foram preparadas soluções nas concentrações correspondentes ao valor da CIM para a bactéria avaliada. Para isso, escolheu-se a emulsão QGOC(E) que apresentou melhores resultados durante o estudo da atividade antimicrobiana e a bactéria Staphylococcus aureus que mostrou maior sensibilidade. A emulsão QGOC(E) foi formulada em concentrações $4 x>C I M$ após os testes de atividade antimicrobiana dos compostos separadamente, conforme item 5.5 e para o preparo da solução estoque, esta foi diluída 4x em meio de cultura.

\subsubsection{Procedimento para obtenção da curva de sobrevivência}

(1) $10 \mathrm{~mL}$ da solução estoque da emulsão em caldo $\mathrm{MH}$ na concentração correspondente a CIM foi adicionada em um tubo de ensaio.

(2) ao tubo controle foram adicionados $10 \mathrm{~mL}$ de caldo $\mathrm{MH}$.

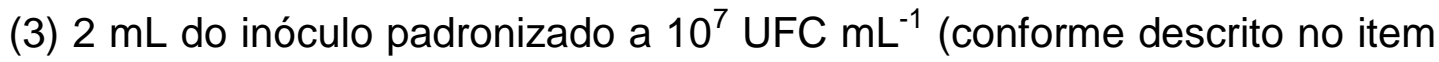
5.9) foram adicionados em cada tubo e agitado em vortex.

(4) uma alíquota de $500 \mu \mathrm{L}$ foi retirada do inóculo padronizado antecedente a adição nos tubos para a contagem do número de células viáveis e uma alíquota de mesmo volume foi retirada de cada tubo para contagem nos diferentes tempos utilizando-se a técnica de diluição sucessiva conforme descrito nos itens 5-8.

(5) foram colocados $4,5 \mathrm{~mL}$ de solução salina $0,86 \%$ em 7 tubos de ensaio. 
(6) adicionou-se ao primeiro tubo $500 \mu \mathrm{L}$ de cada solução, após homogeneização foram transferidos $500 \mu \mathrm{L}$ para o tubo seguinte e assim sucessivamente para obter diluições da amostra e do controle de $10^{-1}$ a $10^{-7}$.

(7) $15 \mu \mathrm{L}$ de cada diluição foram colocados sobre uma placa com meio de enriquecimento TSYEA. As gotas foram depositadas com o auxílio de uma micropipeta.

(8) as placas com as gotas foram incubadas a $37^{\circ} \mathrm{C}$ por $24 \mathrm{~h}$.

(9) este procedimento foi feito nos tempos $0 ; 0,25 ; 2 ; 4 ; 8$ e $24 \mathrm{~h}$.

(10) após $24 \mathrm{~h}$ de incubação, foi feita a contagem do número de colônias e multiplicou-se pelo fator de diluição obtendo-se o valor de UFC $\mathrm{mL}^{-1}$.

\subsection{Ensaio de citotoxicidade}

Os testes de citotoxicidade in vitro foram feitos no Laboratório de Cultura Celular e Fotossensibilizadores - IQSC/USP, pela técnica responsável, Dra. Cláudia Bernal, sob orientação da Profa. Dra. Janice Rodrigues Perussi.

Para os ensaios foi utilizada a linhagem celular VERO (ATCC CCL-81), células epiteliais de rim de macaco verde africano, Cercopithecus aethiops. Essa linhagem cresce aderida, devido a sua morfologia, em garrafas de polipropileno contendo meio de cultura Dulbecco DMEM modificado por Iscove suplementado com $10 \%$ de soro fetal bovino e $0,1 \% \mathrm{v} / \mathrm{v}$ de antibióticos, penicilina $10000 \mathrm{U} . \mathrm{I} . \mathrm{mL}^{-1} \mathrm{e}$ estreptomicina $10 \mathrm{mg} \mathrm{mL}^{-1}$. As células foram incubadas a $37 \stackrel{\circ}{\circ} \mathrm{C}$, em estufa com $5 \%$ de $\mathrm{CO}_{2}$ (FRESHNEY, 2010). Os repiques foram feitos de 1 a 3 vezes por semana e todas as manipulações celulares foram realizadas em condições assépticas, em cabine de segurança biológica, com materiais esterilizados, a fim de se evitar contaminação.

\subsubsection{Determinação da viabilidade e concentração celular}

Para a determinação da viabilidade e concentração celular foi utilizado o método da contagem em câmara de Neubauer e o teste da exclusão do corante 
(FRESHNEY, 2010). Neste teste o corante trypan blue é incorporado pelas células mortas devido ao rompimento da integridade da membrana celular. Para isso, o meio de cultura contido nas garrafas foi removido e uma solução de PBS foi utilizada para retirada do meio de cultura residual. Após lavagem das garrafas com PBS, foi adicionada solução de Tripsina-EDTA 0,02\%, para desprender as células da garrafa. Após 5 minutos, o conteúdo foi transferido para um tubo cônico e centrifugado a 1000 rpm por 1 minuto, descartou-se o sobrenadante e as células foram ressuspendidas em meio de cultura. Uma alíquota de $100 \mu \mathrm{L}$ da suspensão celular foi retirada e adicionada a $400 \mu \mathrm{L}$ de PBS e $500 \mu \mathrm{L}$ de solução 0,4\% de trypan blue. Essa mistura foi colocada na câmara de Neubauer, sendo as células vivas e as mortas contadas com auxílio de um microscópio óptico e a porcentagem de viabilidade foi calculada conforme equação 4 :

$$
\% \text { de viabilidade }=\frac{\text { número de células não coradas }}{\text { número total de células }} \times 100
$$

A concentração de células no meio de cultura utilizada para os ensaios de citotoxicidade em microplacas de 96 poços foi de $1 \times 10^{5}$ células $\mathrm{mL}^{-1}$. Para isso, foram distribuídos $100 \mu \mathrm{L}$ da suspensão celular nas cavidades das placas e incubouse por 24 horas em estufa, a $37{ }^{\circ} \mathrm{C}$ e $5 \%$ de $\mathrm{CO}_{2}$.

\subsubsection{Preparo das amostras}

Os óleos de copaíba $\mathrm{OC}(\mathrm{S}), \mathrm{OC}(\mathrm{C})$ e $\mathrm{OC}(\mathrm{E})$, o gel $\mathrm{QG}$ e as emulsões QGOC(S), QGOC(C) e QGOC(E) foram preparados nas concentrações de 4x > CIM, 2x > CIM e na CIM. Para isso, os óleos de copaíba foram previamente solubilizados em DMSO e esterilizados através de filtração (filtro Millex® da Millipore, com tamanho de poro de 0,22 $\mu \mathrm{m}$ ) então, quantidade suficiente das soluções de óleo em DMSO foram adicionadas ao meio de cultura ISCOVE'S para obtenção das concentrações mencionadas e cuidando para que a concentração do solvente DMSO fosse $1 \%$ no meio. O gel QG e as emulsões foram solubilizados diretamente no meio de cultura ISCOVE'S a pH 5,5, devido ao pKa da quitosana, e foram filtrados para esterilização. Entretanto, a acidificação do meio pode levar a desnaturação do soro fetal bovino. Portanto, utilizou-se, meio de cultura sem adição 
de soro para o preparo destas soluções e após o ajuste de $\mathrm{pH}$ e filtragem, $10 \%$ de soro fetal bovino foi acrescido.

\subsubsection{Ensaio de citotoxicidade celular}

Para o ensaio de citotoxicidade celular foi utilizado o método baseado na capacidade das células viáveis de reduzir o anel tetrazólico presente no sal de MTT (brometo de 3-(4,5-dimetiltiazol-2-il)-2,5-difenil-tetrazólio) pela ação de enzimas desidrogenases presentes na mitocôndria ativa, formando cristais de formazan, de coloração roxa, como exemplificado na Figura 12 (MOSMANN, 1983).

Figura 12 - Princípio da reação de redução do sal de MTT pela desidrogenase mitocondrial das células viáveis.

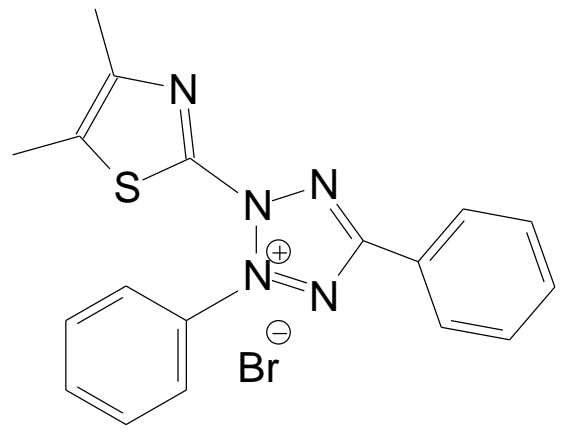

Brometo de tetrazólio

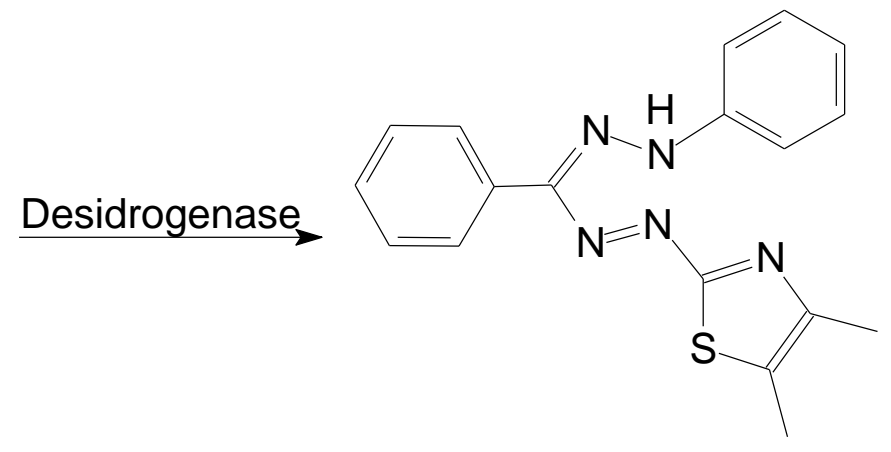

Cristais de formazan

Fonte: Autoria própria.

Às microplacas foram distribuídos $100 \mu \mathrm{L}$ da solução celular por cavidade, e as placas foram incubadas por 24 horas a $37^{\circ} \mathrm{C}$ em estufa contendo tensão constante de $5 \%$ de $\mathrm{CO}_{2}$, conforme item 5.11.1. Após esse período, o sobrenadante foi removido por sucção e adicionou-se 200, 100 e $50 \mu \mathrm{L}$ de cada amostra preparada em 0,100 e $150 \mu \mathrm{L}$ de meio de cultura, respectivamente para obter as concentrações desejadas conforme item 5.13.3, em quadruplicata. Para o controle negativo de células foi utilizado o extrato preparado com papel filtro esterilizado e para o controle positivo utilizou-se extrato preparado com luvas de látex. Incubou-se nas mesmas condições por 24 horas. Após $24 \mathrm{~h}$ as amostras foram removidas por aspiração e as cavidades foram lavadas com $200 \mu \mathrm{L}$ de tampão PBS. Em seguida, adicionou-se $200 \mu \mathrm{L}$ de meio aos poços e as placas foram incubadas por $24 \mathrm{~h}$ a 
$37^{\circ} \mathrm{C}$ em estufa com $5 \%$ de $\mathrm{CO}_{2}$. Posteriormente, foram acrescentados $50 \mu \mathrm{L}$ de uma solução de MTT a $1 \mathrm{mg} \mathrm{mL} \mathrm{mL}^{-1}$ e as placas foram incubadas novamente nas mesmas condições por 3 horas.

Após esse período, o sobrenadante foi removido por aspiração e adicionou-se $50 \mu \mathrm{L}$ de etanol P.A. para diluir os cristais formados. Em seguida, as células foram tratadas com $150 \mu \mathrm{L}$ de álcool isopropílico/PBS na proporção 1:1. A leitura da absorbância foi determinada em leitor da Biotek (Synergy HT) em $570 \mathrm{~nm}$. O índice de sobrevivência celular foi calculado conforme equação 5, considerando o controle negativo como $100 \%$ de viabilidade.

$$
\text { Índice de sobrevivência }(\%)=\frac{\text { média das absorbâncias da amostra }}{\text { média das absorbâncias controle }} \times 100
$$

Para os dados obtidos foram feitos os cálculos de desvio padrão e o teste estatístico $Q$ de Dixon com 95\% de confiança foi utilizado para avaliar a existência de pontos anômalos. 


\section{RESULTADOS E DISCUSSÃO}

\subsection{Obtenção da quitosana}

A quitosana foi obtida através dos processos de desmineralização, desproteinização e desacetilação, descritos anteriormente. O processo de desmineralização consiste na eliminação de sais minerais, principalmente carbonato e fosfato de cálcio. A desproteinização, por sua vez, faz com que ocorra a clivagem das cadeias proteicas contidas entre as cadeias poliméricas da quitina, quebrandoas em peptídeos e até mesmo em aminoácidos livres, removendo-as (CAMPANAFILHO et al., 2007).

O conteúdo de $\beta$-quitina encontrado neste trabalho foi de $38,6 \%$ em relação a massa inicial de gládios de lula $(40,0 \mathrm{~g})$ estando de acordo com Kurita et al. (1993) que relata que os gládios de lula são constituídos por 35-40\% de $\beta$-quitina, 60-65\% de proteínas e uma quantidade mínima de sais inorgânicos.

A desacetilação, última etapa do procedimento, promove a substituição dos grupos acetamida por grupos amina, obtendo-se a quitosana propriamente dita. O rendimento, em relação à massa inicial de gládios de lula, foi de $28,5 \%$, valor em acordo com Chandumpai et al. (2004).

A quitosana obtida tem aparência de um pó branco e fino que pode ser visualizada na Figura 13.

Figura 13 - Quitosana obtida no processo de desacetilação da $\beta$-quitina.

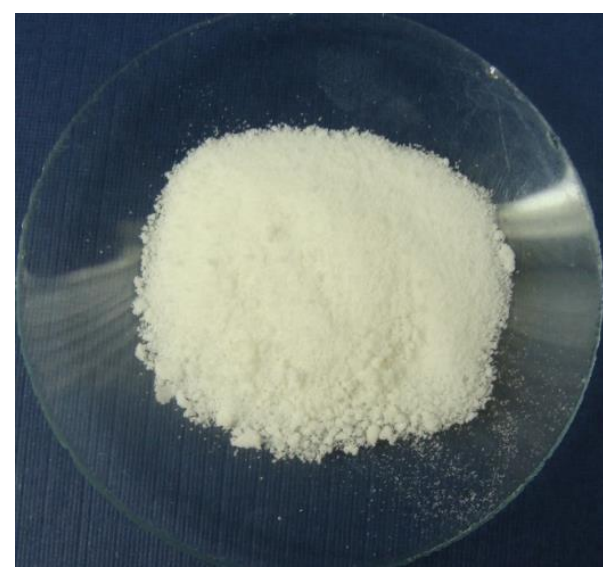

Fonte: Autoria própria. 


\subsection{Caracterização da quitosana}

\subsubsection{Determinação do grau médio de acetilação por titulação condutimétrica}

O grau médio de acetilação da quitosana foi determinado por condutimetria (TORRES et al., 2005), que se trata da titulação de uma mistura de um ácido forte e de um ácido fraco (quitosana em ácido clorídrico) utilizando uma base forte $(\mathrm{NaOH})$ como titulante.

A curva condutimétrica da amostra de quitosana com solução de $\mathrm{NaOH}$ e excesso de ácido clorídrico (Figura 14) mostra três ramos lineares, onde o primeiro corresponde à neutralização do ácido presente, o segundo à desprotonação dos grupos amino da quitosana e o terceiro ao excesso de base, após o ponto de equivalência. Estas três retas originam, por extrapolação, dois pontos de inflexão ( $v_{1}$ e $v_{2}$ ), que correspondem ao volume de base necessário para neutralizar os grupos amino protonados.

Figura 14 - Curva de titulação condutimétrica da quitosana.

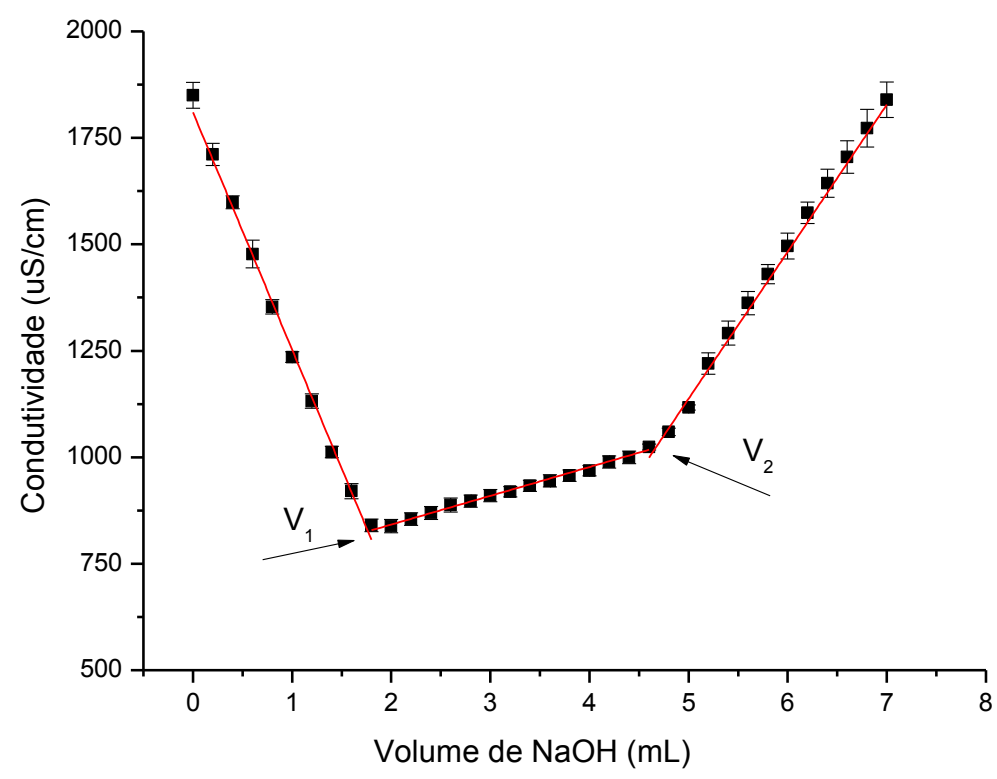

Com os valores de $v_{1}$ e $v_{2}$ obtidos pelos pontos de equivalência, o grau médio de acetilação foi determinação utilizando-se a equação 6 : 


$$
\% G A=\frac{\left(1-161 \times\left(v_{2}-v_{1}\right) \times[\mathrm{NaOH}]\right.}{m} \times 100
$$

na qual, GA = grau médio de acetilação; 161 = massa molar média da unidade repetitiva de quitosana $\left(\mathrm{g} \mathrm{mol}^{-1}\right) ;\left(\mathrm{v}_{2}-\mathrm{v}_{1}\right)=$ volume de solução de hidróxido de sódio consumido para neutralizar a quitosana $(\mathrm{L}) ;[\mathrm{NaOH}]=$ concentração da solução de hidróxido de sódio $\left(\mathrm{mol} \mathrm{L}^{-1}\right)$ e $\mathrm{m}$ = massa de quitosana contida na alíquota titulada (g).

A titulação condutimétrica foi feita em triplicata e o grau médio de acetilação obtido foi de $9,7 \% \pm 1,2$, ou seja, obteve-se uma quitosana com aproximadamente 90,3 \% de desacetilação. A titulação condutimétrica é uma técnica simples, de baixo custo e não destrutível e fornece resultados próximos àqueles obtidos por RMN ${ }^{1} \mathrm{H}$ (HORN, 2012; ALVARENGA; OLIVEIRA; BELLATO, 2010).

Mellegard et al. (2011) estudaram quitosanas com graus de acetilação de $16 \%$ a $48 \%$ e sua influência na atividade antibacteriana. Os autores observaram que o menor grau de acetilação (16\%) foi mais eficaz na inibição das bactérias testadas em relação ao maior grau de acetilação (48\%). Em outro estudo relatado por Younes et al. (2014), também foi avaliado a influência do grau de acetilação na atividade antimicrobiana da quitosana, variando entre 2 - 61\% e verificou-se que quanto menor o grau de acetilação, melhor a atividade bactericida da quitosana. Esses resultados corroboram com os deste estudo em relação a eficácia da quitosana de baixo grau de acetilação na inibição bacteriana.

\subsubsection{Determinação da massa molar média por viscosimetria}

A viscosimetria é um dos processos mais utilizados para determinar a massa molar de polímeros (SANTOS et al., 2003). A viscosidade de um polímero em ácido diluído ou tampão pode ser descrita em função da sua viscosidade intrínseca. A viscosidade intrínseca da amostra de quitosana foi determinada pela extrapolação da reta obtida através da curva de viscosidade reduzida em função da concentração das soluções de quitosana em tampão ácido acético/acetado de sódio (Figura 15). 
Figura 15 - Curva de viscosidade reduzida versus concentração da amostra de quitosana.

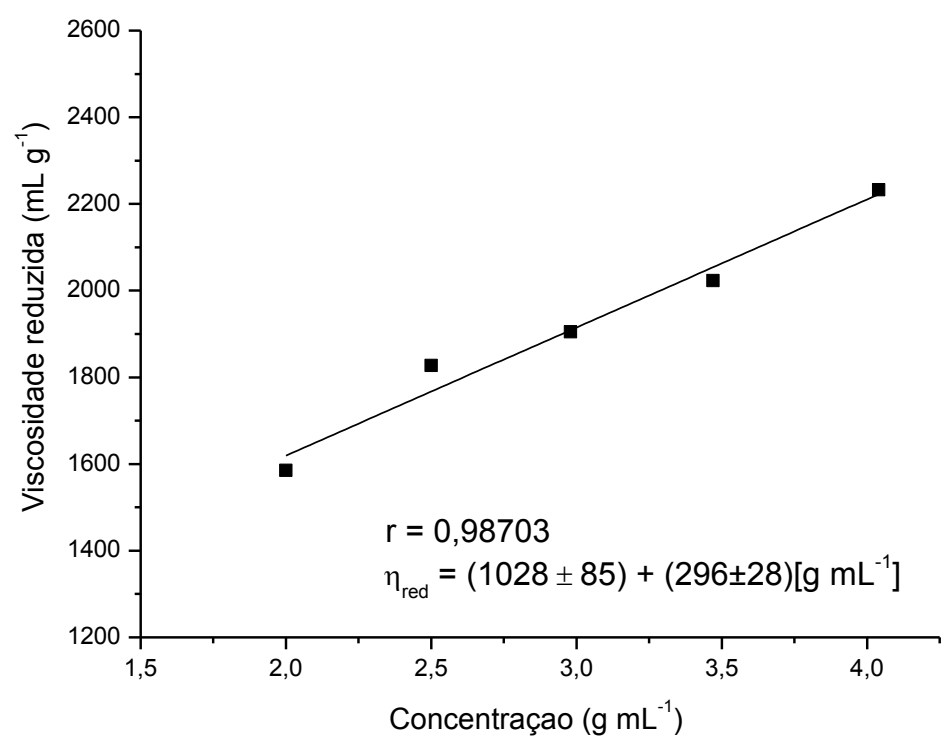

A viscosidade intrínseca obtida foi de $1028 \pm 85 \mathrm{~mL} \mathrm{~g}^{-1}$. Esse valor está relacionado com a massa molar viscosimétrica média da quitosana, podendo esta ser determinada através da equação de Mark-Houwink (Equação 3).

Substituindo-se os valores das constantes tabeladas e 0 valor da viscosidade intrínseca na equação de Mark-Houwink, o valor da massa molecular encontrado foi de $1,5 \times 10^{5} \mathrm{~g} \mathrm{~mol}^{-1}$, sendo considerada uma quitosana de alta massa molar (DASH et al., 2011; CAMPANA-FILHO et al., 2007).

A massa molar também é um fator descrito na literatura como determinante na atividade antimicrobiana da quitosana. Younes et al. (2014) estudaram diferentes quitosanas com massa molar entre 42,5 - 135 kDa e verificaram que os efeitos foram diferentes para bactérias Gram-positivas e Gramnegativas, sendo as primeiras melhor inibidas por quitosana de maior massa molar, enquanto a quitosana de menor massa molar foi mais eficiente para as bactérias Gram-negativas. Mellegard et al. (2011) em estudo similar não verificaram diferenças significativas em relação a massa molar. Neste estudo, a alta massa molar da quitosana também não influenciou na inibição de bactérias Gram-positivas e Gramnegativas. 


\subsection{Espectroscopia na região do infravermelho (FTIR)}

A espectroscopia na região do infravermelho foi feita para verificar se as características da quitosana, da gelatina e dos óleos de copaíba foram mantidas após o processo de emulsificação. A radiação infravermelha corresponde à parte do espectro eletromagnético entre as regiões do visível e das micro-ondas, sendo a porção de maior utilidade para a análise de grupos funcionais de estruturas orgânicas, como a quitosana, a gelatina e o óleo de copaíba, situada na região entre 4000 e $400 \mathrm{~cm}^{-1}$. Essa radiação emitida no infravermelho faz com que átomos de compostos orgânicos vibrem com amplitude aumentada ao redor das ligações covalentes que os ligam e, dessa forma, as linhas se sobrepõem dando origem a uma série de bandas observadas no espectro vibracional.

Os espectros dos óleos de copaíba (Figura 16) mostram as bandas características em $1747 \mathrm{~cm}^{-1}$ referente aos grupos carbonila encontrados em diterpenos como o ácido copálico. Bandas em 1464 e $883 \mathrm{~cm}^{-1}$ referem-se à deformação axial e angular das ligações $-\mathrm{CH}$ e em $1165 \mathrm{~cm}^{-1}$ correspondem a deformação axial de C-O (FAYAD, 2010). O óleo de copaíba escuro OC(E) mostra ainda banda larga entre $3700-3000 \mathrm{~cm}^{-1}$ e alargamento das bandas na região de $1600 \mathrm{~cm}^{-1}$ referindo-se as bandas da ligação O-H da água.

Figura 16 - Espectros no infravermelho para os óleos de copaíba: (-) OC(S), (-) OC(C) e $(-) \mathrm{OC}(\mathrm{E})$.

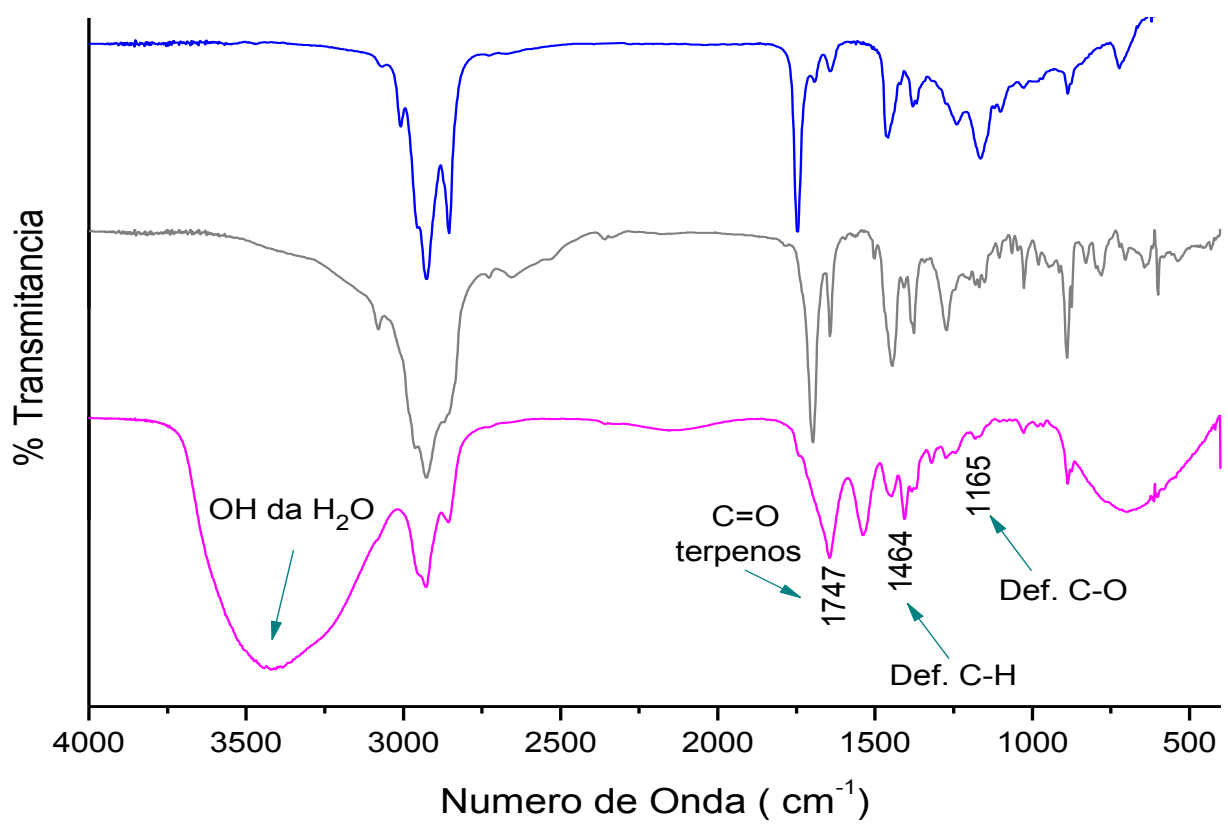


Os espectros obtidos para as três amostras estudadas estão apresentados na Figura 17 e não foram observadas alterações em relação aos valores das bandas teóricas. O espectro de FTIR do óleo de copaíba OC(S) utilizado para exemplificar a comparação das amostras mostra as bandas características mencionadas anteriormente (Figura 16). Para o filme obtido a partir do gel QG observou-se bandas em: $1656 \mathrm{~cm}^{-1}$ referentes à amida I (deformação $\mathrm{C}=\mathrm{O}$ ); $1556 \mathrm{~cm}^{-1}$ amida II (deformação $\mathrm{N}-\mathrm{H}$ ); $1251 \mathrm{~cm}^{-1}$ correspondendo às vibrações no plano da amida III, e $1412 \mathrm{~cm}^{-1}$ devido a deformação da ligação $\mathrm{C}-\mathrm{H}$, que são bandas características para esses dois biopolímeros (KAKKAR et al., 2014; KUMIRSKA et al., 2010).

A comparação entre os espectros do óleo de copaíba e do filme QG com o espectro obtido a partir da emulsão QGOC(S), utilizada para ilustrar a mistura, não levou a mudanças na estrutura dos biopolímeros e do óleo $\mathrm{OC}(\mathrm{S})$, uma vez que, não ocorreu deslocamentos em suas bandas características. Esse mesmo padrão de bandas para as amostras QGOC indicam que as características químicas dos óleos de copaíba e do gel QG foram mantidas após o processo de emulsificação.

Figura 17 - Espectro no infravermelho para: (-) OC(S), (-) QG e (-) QGOC(S).

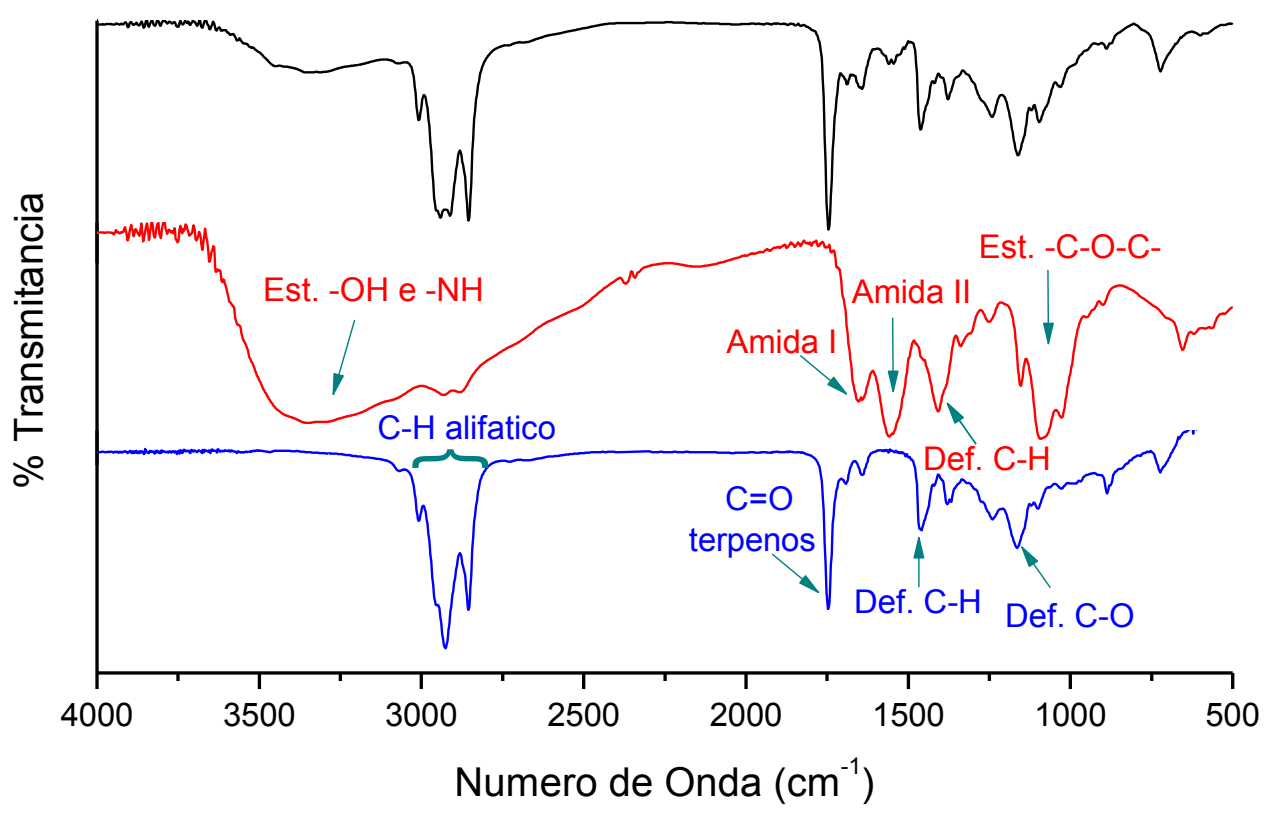




\subsection{Análise macroscópica e microscópica das emulsões}

Durante o período de armazenamento (temperatura $4 \stackrel{\circ}{\circ}$ ) das emulsões (aproximadamente 5 meses) não foram observadas alterações macroscópicas nas formulações, exibindo sinais de homogeneidade sem a presença de sedimentação, coalescência e alterações de cor. O mesmo aconteceu quando deixadas a temperatura ambiente $\left(25^{\circ} \mathrm{C}\right)$.

A análise microscópica das formulações como ilustrado na Figura 18 revelou homogeneidade e presença de partículas esféricas de diâmetro similares, o que sugere a formação de micro gotículas dos óleos no sistema quitosana/gelatina na rede das emulsões. A emulsão obtida a partir do óleo de copaíba escuro mostra uma menor formação de gotículas de óleo dentro do sistema polimérico da emulsão, devido a menor concentração de óleo utilizada em sua formulação.

Figura 18 - Fotografia digital das emulsões: (A) QGOC(S), (B) QGOC(C) e (C) QGOC(E). Aumento de 10x. As setas indicam as gotículas dos óleos.
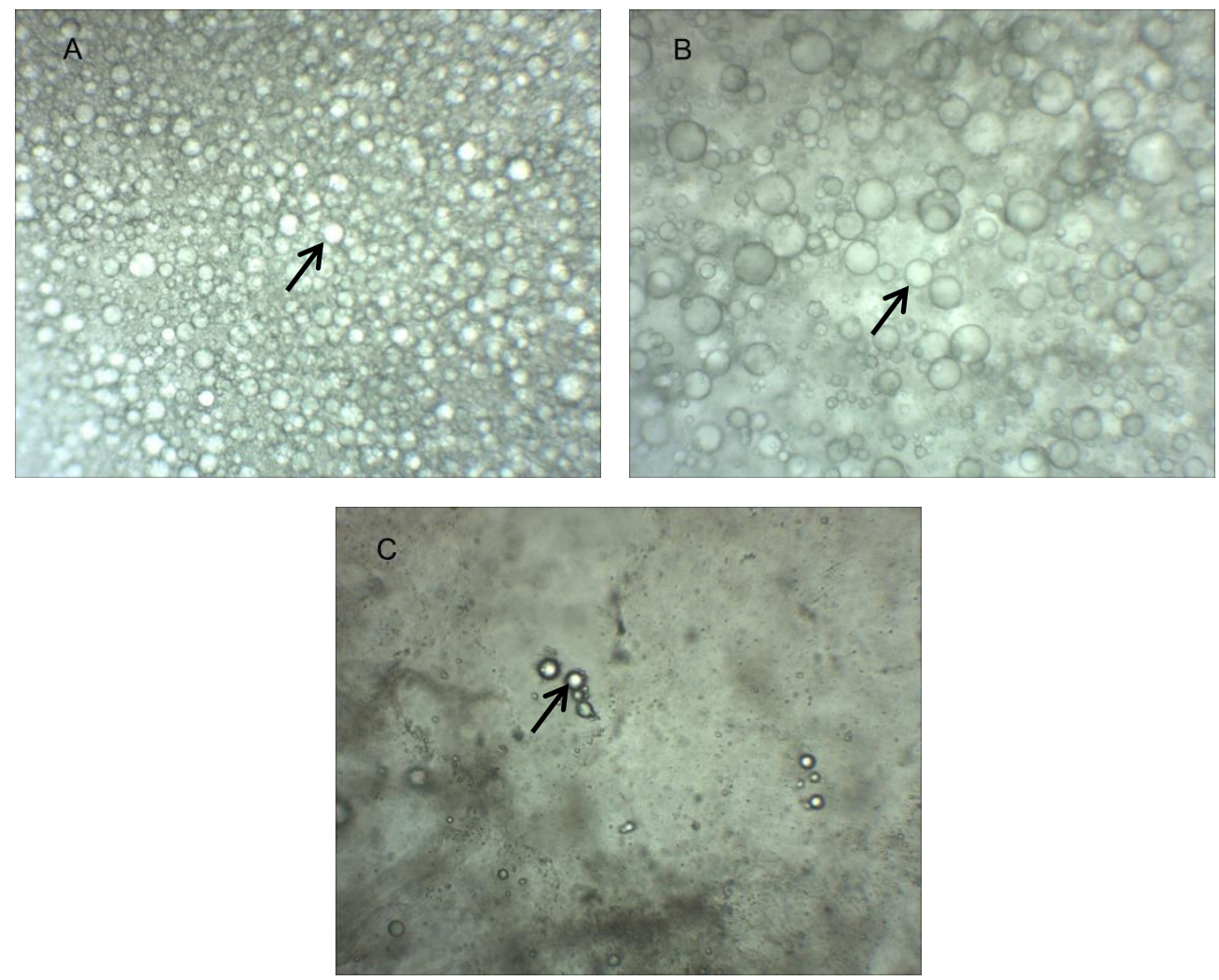

Fonte: Autoria própria. 


\subsection{Testes de estabilidade das emulsões}

\subsubsection{Teste de centrifugação}

As formulações submetidas aos ciclos de 1000, 1500, 2500, 3000 e 3500 rpm de centrifugação durante 15 min a $25 \stackrel{\circ}{C}$ mostraram-se visualmente estáveis quando comparadas à formulação inicial (24 h após o preparo) (Figura 19), passíveis à submissão de outras condições de tensão. O procedimento de centrifugação é eficaz na determinação da instabilidade dos produtos emulsificados, já que a simulação de aumento da força de gravidade pode promover a separação de componentes de diferentes densidades, como nas fases óleo e água (RIEGER, 1996). Segundo Idson (1993), a força centrífuga acelera a sedimentação, cremeação ou coalescência do sistema, permitindo avaliar visualmente a aparência da emulsão e verificar rapidamente, o comportamento das gotículas emulsionadas frente à força da gravidade.

Figura 19 - llustração das emulsões de QGOC submetidas aos ciclos de centrifugação: (A) sem centrifugar, (B) $1000 \mathrm{rpm}$, (C) $1500 \mathrm{rpm}$, (D) $2500 \mathrm{rpm}$, (E) $3000 \mathrm{rpm}$ e (F) $3500 \mathrm{rpm}$.

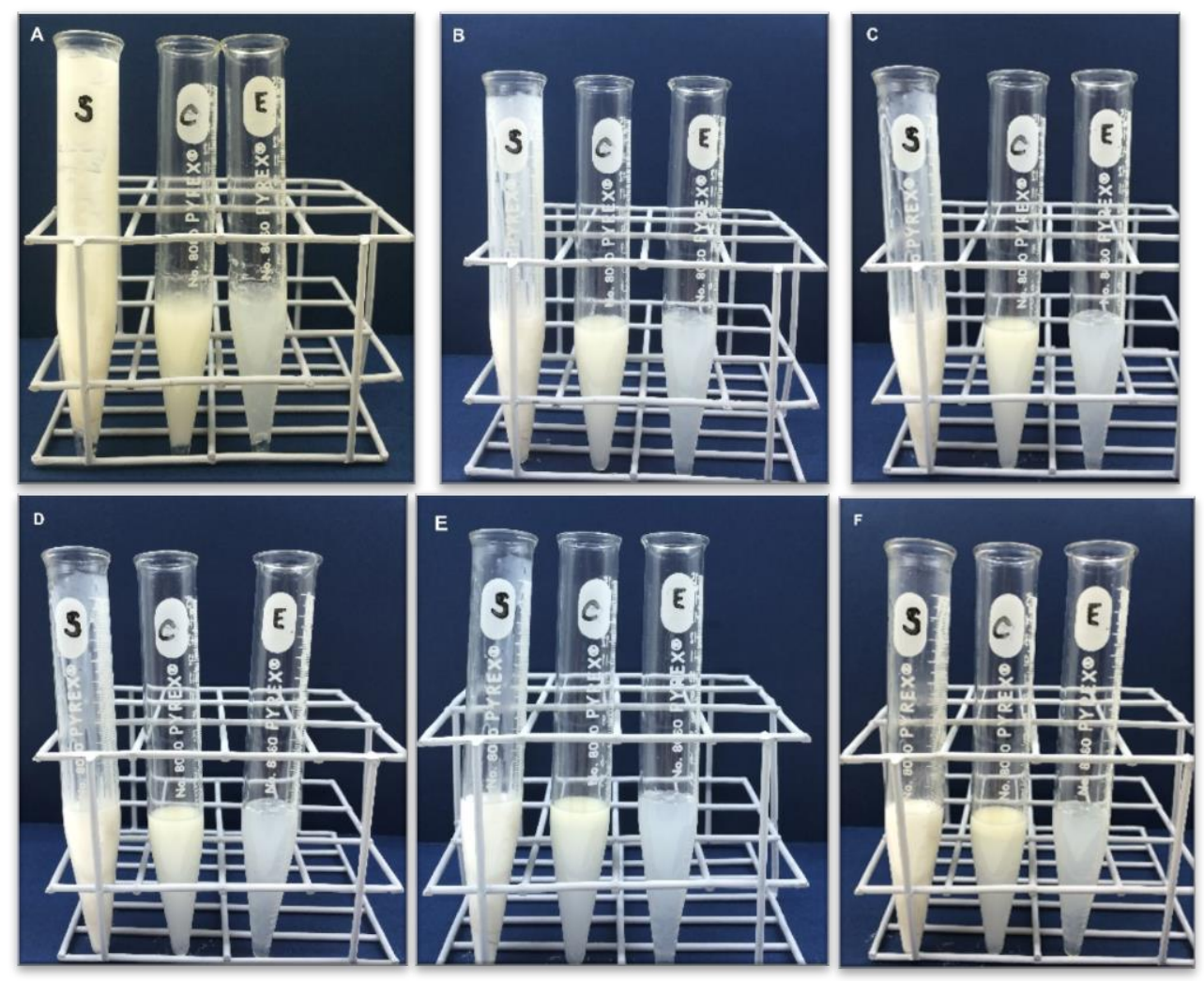

Fonte: Autoria própria. 


\subsubsection{Estresse térmico}

No teste de estresse térmico, as emulsões apresentaram-se macroscopicamente estáveis e não ocorreu separação de fases até a temperatura de $70 \stackrel{\circ}{\circ}$. A temperatura é um importante parâmetro de estabilidade, uma vez que, a variação de temperatura pode comprometer o processo de armazenamento e transporte do produto. Neste estudo utilizou-se o teste de estresse térmico proposto por BRACONI et al. (1995), que emprega a temperatura como condição de tensão sobre a formulação e é um teste de rápida execução. A Figura 20 mostra as emulsões antes e depois de serem submetidas às diferentes temperaturas.

Figura 20 - llustração das emulsões QGOC após as variações de temperatura: (A) $25^{\circ} \mathrm{C}$, (B) $45^{\circ} \mathrm{C},(\mathrm{C}) 50^{\circ} \mathrm{C}$, (D) $60^{\circ} \mathrm{C}$ e (E) $70^{\circ} \mathrm{C}$.

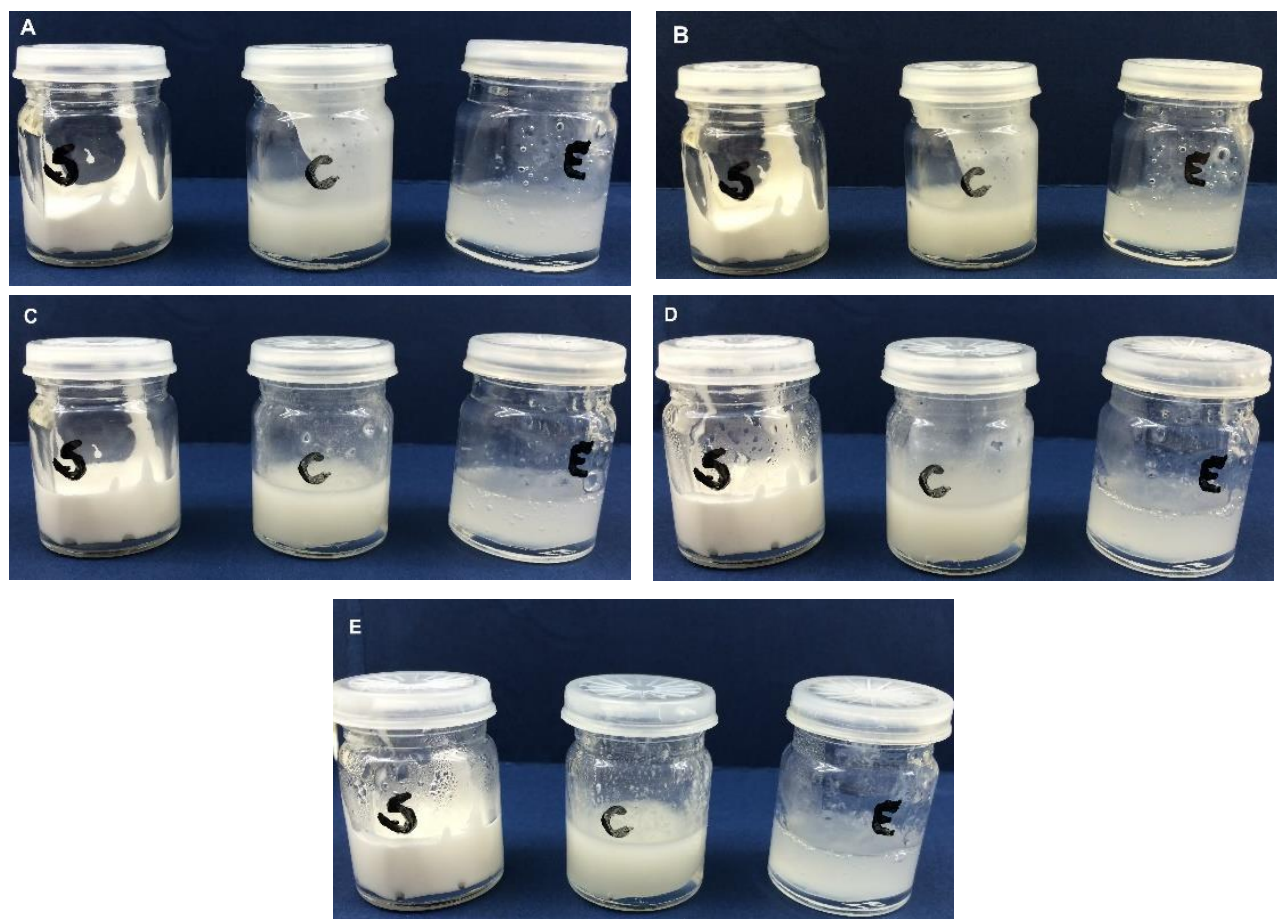

Fonte: Autoria própria.

As amostras também foram avaliadas macroscopicamente a cada mudança ocasional de temperatura durante a execução dos ensaios microbiológicos (temperatura ambiente de $25^{\circ} \mathrm{C}$, temperatura de armazenamento em geladeira $4 \stackrel{\circ}{\circ} \mathrm{C}$ e estufa $45^{\circ} \mathrm{C}$ ) e, permaneceram inalteradas com coloração esbranquiçada e odor forte e característico dos óleos de copaíba. 
A variação de temperatura prevê o comportamento dos produtos nos diversos ambientes a que possa ser submetido e neste estudo, as emulsões mostraram-se estáveis em todas as condições a que foram submetidas, sem alterações no aspecto, cor, odor, separação de fases ou precipitação.

\subsection{Determinação dos valores de pH}

Os valores de $\mathrm{pH}$ das formulações durante o período de estudo são mostrados na Tabela 1. Após $24 \mathrm{~h}$ de preparo das emulsões e depois de serem submetidas às condições de estresse, os valores de $\mathrm{pH}$ permaneceram os mesmos indicando a estabilidade das amostras.

Tabela 1 - Valores de pH das emulsões de quitosana/gelatina/óleo de copaíba submetidas aos diferentes testes de estabilidade.

\begin{tabular}{cccc}
\hline \multirow{2}{*}{ Condições } & \multicolumn{3}{c}{ Valor de pH } \\
\cline { 2 - 4 } & QGOC(S) & QGOC(C) & QGOC(E) \\
\hline 24 h de preparo & 5,5 & 5,8 & 6,5 \\
Centrifugação & 5,5 & 5,8 & 6,5 \\
Geladeira $(4 \stackrel{\circ}{\circ})$ & 5,5 & 5,8 & 6,5 \\
Temperatura & 5,5 & 5,8 & 6,5 \\
ambiente $\left(\sim 25^{\circ} \mathrm{C}\right)$ & & & \\
Estufa $\left(45^{\circ} \mathrm{C}\right)$ & 5,5 & 5,8 & 6,5 \\
\hline
\end{tabular}

Fonte: Autoria própria.

\subsection{Influência do pH no crescimento bacteriano}

O meio de cultura caldo Müeller Hinton em pH 5,0 mostrou uma redução significativa no número de microrganismos em 4 log em comparação ao controle, não podendo ser utilizado esse $\mathrm{pH}$ para os ensaios, uma vez que, influenciou o crescimento bacteriano. Já, o meio em pH 5,5 não reduziu o número de microrganismos, sendo equivalente ao meio em pH 7,4 (Tabela 2). A bactéria $S$. aureus cresceu 2 log a mais em relação ao pH padrão, uma vez que, este é o pH da 
pele, onde a bactéria está presente em condições favoráveis (TORTORA; FUNKE; CASE, 2012; GRICE e SEGRE, 2011). Portanto, todos os ensaios de atividade antimicrobiana foram feitos com o meio de cultura caldo Müeller Hinton em pH 5,5 para que o gel QG fosse solubilizado de modo homogêneo no meio de cultura e não ocorresse precipitação. Os ensaios de atividade antimicrobiana dos óleos de copaíba também foram feitos em $\mathrm{pH}$ 5,5 para padronização dos resultados.

Tabela 2 - Comparação entre o pH padrão do meio de cultura com o pH 5,5 utilizado nos ensaios de atividade antimicrobiana.

\begin{tabular}{cccc}
\hline \multirow{2}{*}{ Linhagens } & \multicolumn{3}{c}{ D. $\mathbf{0 .}$} \\
\cline { 2 - 4 } & $\mathbf{p H ~ 5 , 0}$ & $\mathbf{p H ~ 5 , 5}$ & $\mathbf{p H ~ 7 , 4}$ \\
\hline S. aureus & 0,32 & 0,85 & 0,67 \\
E. coli & 0,62 & 0,81 & 0,91 \\
P. aeruginosa & 0,02 & 0,73 & 0,71 \\
\hline
\end{tabular}

Fonte: Autoria própria.

\subsection{Atividade antimicrobiana dos óleos de copaíba}

Os óleos de copaíba utilizados neste trabalho apresentaram atividade apenas contra a bactéria Gram-positiva Staphylococcus aureus como mostrado na Tabela 3.

Tabela 3 - Valores de CIM e CBM dos diferentes óleos de copaíba (OC) sobre S. aureus.

\begin{tabular}{ccc}
\hline Óleos & CIM $\left(\mu \mathrm{g} \mathrm{mL}^{-1}\right)$ & CBM $\left(\mu \mathrm{gL}^{-1}\right)$ \\
\hline OC $(\mathrm{S})$ & 2000 & 2000 \\
OC $(C)$ & 500 & 500 \\
OC $(E)$ & 62,5 & 62,5 \\
\hline
\end{tabular}

Fonte: Autoria própria.

O óleo de copaíba advindo de São Paulo mostrou uma concentração inibitória mínima (CIM) e concentração bactericida mínima (CBM) de $2000 \mu \mathrm{g} \mathrm{m}^{-1}$, 
enquanto que os óleos de copaíba adquiridos no mercado municipal de Belém mostraram uma CIM de $500 \mu \mathrm{g} \mathrm{mL}^{-1}$ para o óleo claro OC(C) e $62,5 \mu \mathrm{g} \mathrm{m}^{-1}$ para o óleo escuro $\mathrm{OC}(\mathrm{E})$, respectivamente (Figura 21). Todos os óleos testados não apresentaram atividade contra as bactérias Gram-negativas até $4000 \mu \mathrm{g} \mathrm{mL}$ (Escherichia coli e Pseudomonas aeruginosa) estando de acordo com os dados apresentados na literatura (MASSON et al., 2013; SANTOS et al., 2008).

Figura 21 - llustração da determinação da CIM da linhagem de S. aureus, com as diferentes concentrações de $\mathrm{OC}(\mathrm{E})$.

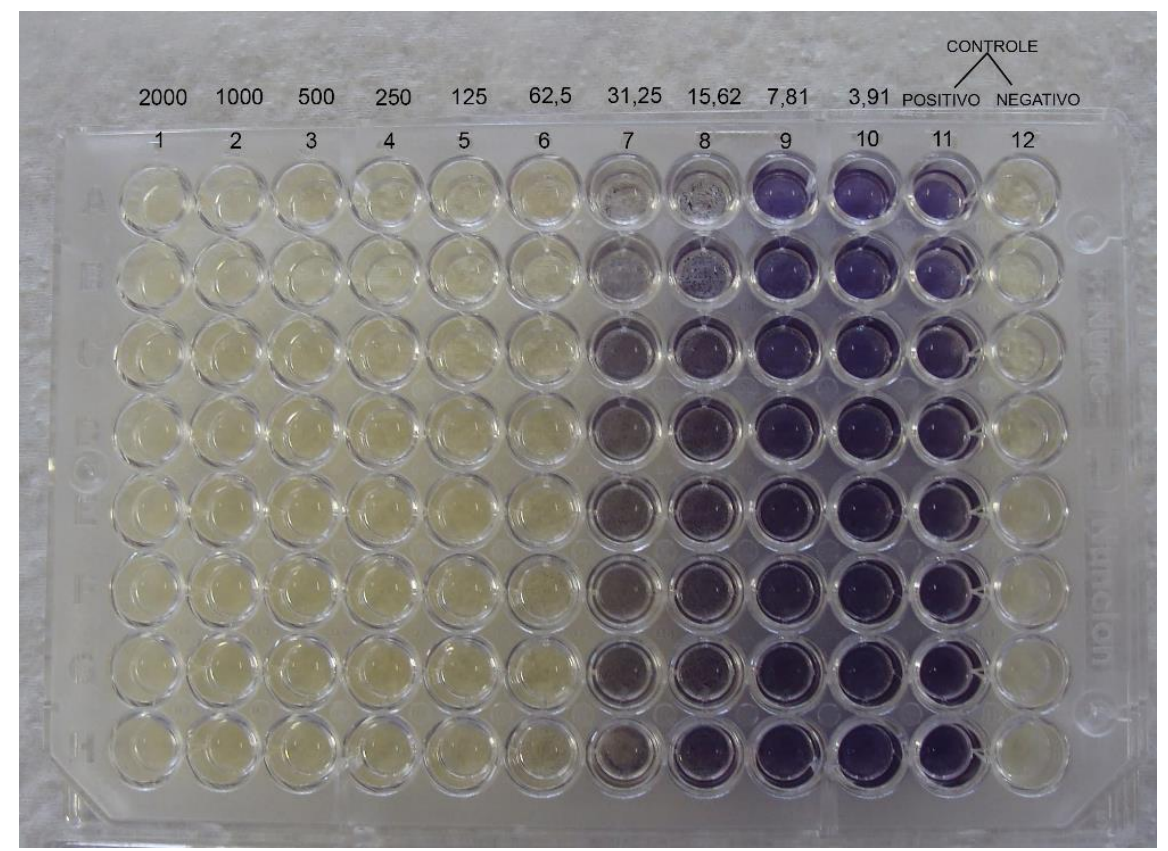

Fonte: Autoria própria.

Santos et al. (2008) compararam a atividade antimicrobiana de diferentes espécies de árvores do gênero Copaifera, além do comparativo entre espécies de diferentes regiões. Os valores de CIM e CBM relatados para a linhagem de $S$. aureus são mostrados na Tabela 4.

Em outro estudo observado por Masson et al. (2013), os valores de CIM e CBM observados para o óleo de copaíba obtido a partir de Copaifera langsdorffi foram de $200 \mathrm{\mu g} \mathrm{mL}^{-1}$ para $S$. aureus (ATCC 6538) e, também foi relatado a não inibição de bactérias Gram-negativas. Esses diferentes perfis de sensibilidade entre diferentes espécies de copaibeiras e entre mesmas espécies de diferentes regiões também foram observados neste estudo.

No mesmo estudo descrito por Santos et al., 2008 foi observado por análise de microscopia eletrônica de transmissão o rompimento da parede celular, 
extravasamento do conteúdo citoplasmático e perda do volume celular em $S$. aureus após o tratamento com óleo de copaíba durante $3 \mathrm{~h}$. Isso indica que o óleo deve atuar na parede celular, sugerindo que a ausência de atividade em bactérias Gramnegativas está diretamente relacionada com a diferença estrutural entre estas e as bactérias Gram-positivas.

Tabela 4 - Concentração inibitória mínima/concentração bactericida mínima de diferentes espécies do gênero Copaifera sobre $S$. aureus.

\begin{tabular}{lc}
\hline \multicolumn{1}{c}{ Óleos } & S. aureus (ATCC 25923) \\
\hline Copaifera reticulata (Pará) & $>1000 / \mathrm{nt}^{\mathrm{a}}$ \\
Copaifera reticulata (Acre) & $62,5 / 62,5$ \\
Copaifera martii & $62,5 / 62,5$ \\
Copaifera cearenses & $250 / 1000$ \\
Copaifera paupera & $250 / 1000$ \\
Copaifera langsdorfii & $>1000 / \mathrm{nt}^{\mathrm{a}}$ \\
Copaifera officinalis & $62,5 / 62,5$ \\
Copaifera multijuga & $500 / 1000$ \\
Copaifera lucens & $125 / 500$ \\
\hline
\end{tabular}

a - Não testado.

Fonte: Adaptado de SANTOS et al., 2008.

Um dos principais fatores envolvidos na toxicidade seletiva de ação antibacteriana reside na membrana externa de lipopolissacarídeos de bactérias Gram-negativas e nas porinas, proteínas que formam canais aquosos através dessa membrana. Para penetrar esses canais, um antimicrobiano precisa ser relativamente pequeno e preferencialmente hidrofílico, pois a afinidade por lipídeos ou o tamanho impedem a sua passagem. Além disso, o antimicrobiano pode ser expelido por essas proteínas que agem como bombas, impedindo o alcance de uma concentração efetiva. Outro fator determinante é a presença de enzimas que degradam ou inativam o antimicrobiano, principalmente antimicrobianos de origem natural. Esse fato explica o porquê bactérias Gram-negativas apresentam perfil de 
sensibilidade mais restrito aos antimicrobianos e sugere uma hipótese para a não inibição destas quando tratadas com o óleo de copaíba (TORTORA; FUNKE; CASE, 2012; GRICE e SEGRE, 2011).

Contudo, estudos utilizando metodologia qualitativa (Método de disco difusão) relataram a inibição das bactérias Gram-negativas $E$. coli e $P$. aeruginosa (PIERI et al., 2012; MENDONÇA e ONOFRE, 2009). Isso sugere que as diferenças encontradas entre os estudos também estão relacionadas com as diferentes espécies do gênero Copaifera, que apresentam variações nas características físicoquímicas, bem como na constituição química dos óleos. Além disso, características do solo, da região e a sazonalidade afetam a atividade biológica dos óleos mesmo que entre os mesmos tipos de espécies (PIERI et al., 2012; SANTOS et al., 2008).

A atividade biológica dos óleos resina de copaíba tem sido atribuída aos sesquiterpenos e diterpenos. Entre os sesquiterpenos com atividade antimicrobiana reconhecida estão o $\beta$-cariofileno (GOREN et al., 2011) e o $\delta$-cadineno (PÉREZLÓPEZ et al., 2011; KUBO; MUROI; HIMEJIMA, 1992) e, entre os diterpenos o ácido copálico (SANTOS et al., 2011; TINCUSI et al., 2002), o ácido hardwíckico (KUETE et al., 2007; MCCHESNEYA; CLARK; SILVEIRA, 1991) e o ácido caurenóico (TINCUSI et al., 2002). Essas variações na composição dos óleos, além das características genotípicas e fenotípicas de cada linhagem bacteriana, com perfis de resistência diferentes podem explicar a variação encontrada na sensibilidade.

\subsection{Atividade antimicrobiana do gel de quitosana/gelatina}

O gel QG foi eficiente contra todas as linhagens bacterianas estudadas. Os valores de CIM e CBM encontrados para cada linhagem bacteriana testada estão apresentados na Tabela 5.

Os valores de CIM encontrados para o gel QG foram de $31,2 \mu \mathrm{g} \mathrm{mL}^{-1}$ para as bactérias $S$. aureus e $P$. aeruginosa e, de $62,5 \mu \mathrm{g} \mathrm{mL}^{-1}$ para a bactéria $E$. coli, destacando que sua ação foi predominantemente bactericida, exceto para $P$. aeruginosa que não apresentou CBM para as concentrações testadas, possuindo efeito bacteriostático. Esses resultados demonstram que o gel QG apresentou potencial antimicrobiano sobre as linhagens estudadas, como mostra a Figura 22. 
Tabela 5 - Valores de CIM e CBM do gel QG sobre $S$. aureus, E. coli e $P$. aeruginosa.

\begin{tabular}{ccc}
\hline $\begin{array}{c}\text { Linhagens } \\
\text { bacterianas }\end{array}$ & $\mathrm{CIM}\left(\boldsymbol{\mu g} \mathrm{mL}^{-1}\right)$ & $\mathrm{CBM}\left(\boldsymbol{\mu g} \mathrm{mL}^{-1}\right)$ \\
\hline S. aureus & 31,2 & 31,2 \\
E. coli & 62,5 & 62,5 \\
P. aeruginosa & 31,2 & $>4000$ \\
\hline
\end{tabular}

Fonte: Autoria própria.

Figura 22 - Ilustração da determinação da CIM da linhagem de $P$. aeruginosa, com as diferentes concentrações do gel QG.

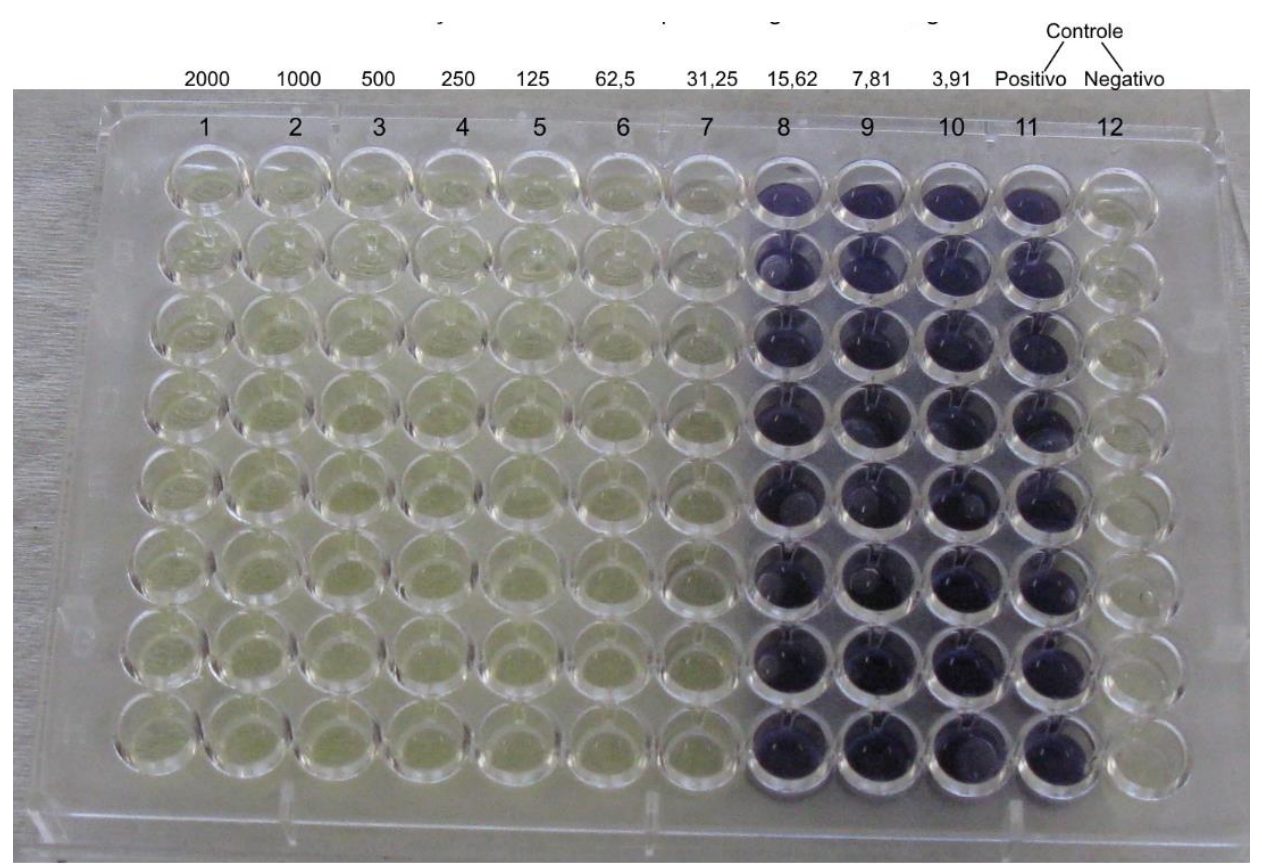

Fonte: Autoria própria.

Em estudo relatado por Islam et al. (2011) utilizando quitosana derivada da biomassa de caranguejos a CIM encontrada foi maior que a encontrada neste estudo (1200 e $1300 \mathrm{\mu g} \mathrm{mL}^{-1}$ para S. aureus e E. coli, respectivamente).

Já em estudos feitos com quitosana quaternizada, ou seja, quitosana na qual foram introduzidos grupos hidrofílicos para aumentar a solubilidade, como por exemplo a adição de grupos amônio carregados positivamente, utilizando (3-cloro-2hidroxi-propil) cloreto de trimetilamônio (GTMAC) observou-se uma CIM entre 8 e $64 \mu \mathrm{g} \mathrm{mL}^{-1}$ para S. aureus e 16 a $64 \mu \mathrm{gL}^{-1}$ para E. coli (SAJOMSANG et al., 2009). Em derivados obtidos da metilação de $N$-aril-quitosana contendo como substituintes $N, N$-dimetilaminofenil e $N$-4-piridilmetil (SAJOMSANG et al., 2008), os quais produzem sais quaternários de amônio na presença de iodeto de sódio e de 
iodometano, observou-se uma CIM entre 32 a $128 \mu \mathrm{g} \mathrm{mL}^{-1}$ para as mesmas bactérias (TAN et al., 2013). Estes valores são próximos aos encontrados neste estudo com quitosana obtida a partir de gládios de lula e sem derivatização. Tal fato pode ser atribuído à presença de gelatina no gel aumentando a solubilidade e similaridade com a quitosana derivatizada, uma vez que, a atividade antimicrobiana da quitosana é afetada pela solubilidade da cadeia e pela densidade de carga, como descrito por KONG et al. (2010).

Pereda et al. (2011) estudaram a atividade antimicrobiana de filmes de quitosana/gelatina sobre as bactérias Escherichia coli e Listeria monocytogenes através de metodologia qualitativa. Os resultados reportados pelos autores mostram que E. coli e L. monocytogenes foram sensíveis a todos os filmes testados. Contudo, o filme comestível contendo apenas quitosana não formou halos de inibição significativos para nenhum dos agentes patogênicos. Isso demonstra o papel da gelatina na mistura, tendo-se uma maior solubilidade da quitosana no meio e consequentemente uma maior interação com a bactéria, assim como demonstrado neste estudo.

Contudo, há controvérsias na tentativa de explicar o modo de ação que gera a atividade antimicrobiana da quitosana e este ainda não é totalmente compreendido. Vários fatores extrínsecos e intrínsecos relacionados ao microrganismo, como sua genética, e a quitosana como: grau de acetilação, massa molar, solubilidade, capacidade de quelação, $\mathrm{pH}$, força iônica, temperatura e tempo de armazenamento (viscosidade), entre outros, influenciam a relação quitosanabactéria (KONG et al., 2010).

Como descrito na revisão bibliográfica são propostos 3 mecanismos de ação para quitosana. O primeiro ocorre pela interação dos grupos $\mathrm{NH}_{3}{ }^{+}$da quitosana e a superfície bacteriana carregada negativamente, levando a um rompimento da membrana celular (JEON et al., 2014; KONG et al., 2010; RABEA et al., 2003; HELANDER et al., 2001; SUDARSHAN; HOOVER; KNORR, 1992). O segundo mecanismo proposto sugere a inibição do RNAm e da síntese proteica através da ligação direta da quitosana ao DNA do microrganismo e para isso é necessário que a quitosana possua um tamanho capaz de atravessar a parede celular da bactéria (SEBTI et al., 2005; SUDARSHAN; HOOVER; KNORR, 1992; HADWIGER et al., 1981). O terceiro está relacionado com a capacidade da quitosana de ligar-se a 
metais limitando a passagem de nutrientes essenciais a vida bacteriana (WANG et al., 2005; HELANDER et al., 2001; ROLLER e COVILL, 1999).

Além disso, vários estudos relatam diferenças no efeito inibitório da quitosana entre bactérias Gram-positivas e Gram-negativas, enquanto há autores que não observaram diferenças significativas entre as bactérias (KONG et al., 2010; GOY; BRITTO; ASSIS, 2009).

\subsection{Atividade antimicrobiana das emulsões de quitosana/gelatina/óleo de copaíba}

A interação entre duas substâncias pode ser classificada em sinérgica, indiferente ou antagônica. Diz-se que essa é sinérgica quando a somatória dos efeitos na combinação é maior que o efeito isolado das substâncias; indiferente quando a somatória dos efeitos na combinação permanece igual aos compostos individualmente e antagonista, quando, a somatória dos efeitos na combinação é menor que o efeito isolado. Contudo, esses efeitos estão diretamente ligados a dosagem de cada substância em conjunto ou individualmente e ao seu mecanismo de ação (YEH et al., 2010).

Para verificar o tipo de interação entre os óleos de copaíba e o gel de quitosana/gelatina foi avaliada a ação conjunta dos antimicrobianos na forma de emulsões (QGOC) sobre as linhagens $S$. aureus, E. coli e $P$. aeruginosa. Primeiramente, evidenciou-se o efeito dos antimicrobianos isoladamente como discutido nos itens 6.8 e 6.9 .

Levando em consideração que apenas a bactéria Gram-positiva foi inibida pelos óleos de copaíba, as concentrações das emulsões QGOC para as bactérias Gram-negativas foram baseadas na atividade apresentada pelo gel QG e, tendo em vista que a bactéria $E$. coli mostrou menor atividade para o gel em relação a bactéria $P$. aeruginosa, a concentração final das emulsões foi de $2 x>$ CIM para esta.

A partir do mecanismo de ação do óleo de copaíba e da quitosana descritos na literatura, tendo como alvo a parede celular e a membrana citoplasmática, respectivamente pressupôs-se que a ação combinada das duas moléculas poderia apresentar efeito sinérgico. 
Os valores de CIM e CBM dos antimicrobianos na combinação na forma de emulsões QGOC são mostrados na Tabela 6.

Tabela 6 - Valores de CIM e CBM das emulsões QGOC(S), QGOC(C) e QGOC(E).

\begin{tabular}{lccccccc}
\hline & \multicolumn{6}{c}{ Linhagens bacterianas } \\
\cline { 3 - 8 } Emulsão $\left(\mu \mathrm{g} \mathrm{mL}^{-1}\right)$ & \multicolumn{2}{c}{ S. aureus } & \multicolumn{2}{c}{ E. coli } & \multicolumn{3}{c}{$\boldsymbol{P}$. aeruginosa } \\
\cline { 3 - 8 } & & OC & QG & OC & QG & OC & QG \\
\hline \multirow{2}{*}{ QGOC(S) } & CIM & 2000 & 31,2 & $>4000$ & 62,5 & $>4000$ & 62,5 \\
& CBM & 2000 & 31,2 & $>4000$ & 62,5 & $>4000$ & $>4000$ \\
\multirow{2}{*}{ QGOC(C) } & CIM & 500 & 31,2 & $>4000$ & 62,5 & $>4000$ & 62,5 \\
& CBM & 500 & 31,2 & $>4000$ & 62,5 & $>4000$ & $>4000$ \\
\multirow{2}{*}{ QGOC(E) } & CIM & 31,2 & 15,6 & $>4000$ & 62,5 & $>4000$ & 62,5 \\
& CBM & 31,2 & 15,6 & $>4000$ & 62,5 & $>4000$ & $>4000$ \\
\hline
\end{tabular}

Fonte: Autoria própria.

Para a linhagem de $S$. aureus a combinação dos antimicrobianos na forma das emulsões QGOC(S) e QGOC(C) mostrou a mesma atividade apresentada para os óleos de copaíba OC(S) e OC(C) (CIM $2000 \mathrm{\mu g} \mathrm{mL}^{-1}$ e $500 \mathrm{\mu g} \mathrm{mL}^{-1}$, respectivamente) e para o gel $\mathrm{QG}\left(\mathrm{CIM} 31,2 \mu \mathrm{g} \mathrm{\textrm {mL } ^ { - 1 }}\right.$ ) em teste isolado, não caracterizando sinergismo. Já, para a combinação com o óleo de copaíba escuro $\mathrm{OC}(\mathrm{E})$ e o gel QG na emulsão QGOC(E), a concentração necessária para inibir o crescimento da bactéria foi reduzida pela metade (CIM 31,2 $\mathrm{mg} \mathrm{mL}^{-1}$ para o óleo e $15,6 \mu \mathrm{gL}^{-1}$ para o gel QG), sugerindo um possível efeito sinérgico para a bactéria Gram-positiva S. aureus, como mostra a Figura 23.

Huang et al. (2011) observaram que a combinação de acetato de quitosana com nanopartículas de prata apresenta efeito sinérgico sobre a bactéria Gram-positiva resistente a meticilina ( $S$. aureus MRSA) e sobre as bactérias Gramnegativas ( $P$. aeruginosa, Proteus mirabilis e Acinetobacter baumannii). A explicação hipotética sugerida pelos autores para o mecanismo de ação envolve o aumento da permeabilidade celular mediado pela ação da quitosana, permitindo assim a melhor penetração dos íons de prata (HUANG et al., 2011), o que também pode estar ocorrendo neste estudo com o óleo de copaíba. Isso também proporciona uma possível explicação para a melhor atividade em bactérias Gram-positivas, uma vez 
que, as diferenças estruturais destas e das bactérias Gram-negativas geram variações no perfil de sensibilidade.

Figura 23 - Ilustração da combinação dos antimicrobianos sobre $S$. aureus, com as diferentes concentrações da emulsão QGOC(E).

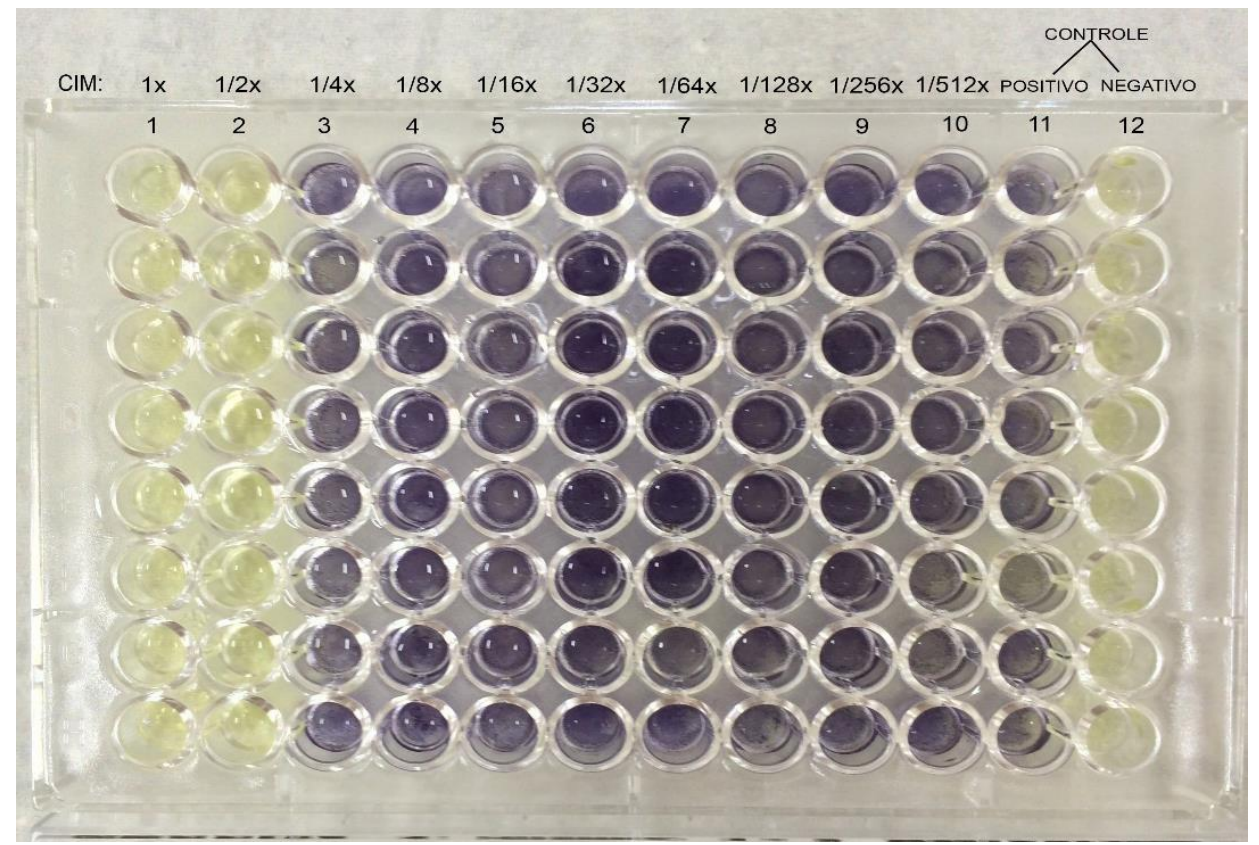

Fonte: Autoria própria.

Como as bactérias Gram-negativas não foram inibidas por nenhum dos óleos foi observado se ocorreria algum tipo de interação dos óleos com o gel QG na forma de emulsões. Para E. coli o efeito do gel QG foi mantido (CIM 62,5 $\mathrm{g} \mathrm{mL}^{-1}$ ) e os óleos continuaram sem atividade, não caracterizando efeito sinérgico entre os antimicrobianos. Entretanto, para a bactéria $P$. aeruginosa o efeito dos óleos de copaíba reduziu a eficácia na atividade do gel QG que passou de uma CIM de $31,2 \mu \mathrm{g} \mathrm{mL}^{-1}$ para $62,5 \mu \mathrm{g} \mathrm{mL}^{-1}$, sugerindo um efeito antagônico. Destaca-se ainda, a manutenção da ação bactericida de todas as emulsões testadas, exceto para $P$. aeruginosa, que teve efeito bacteriostático até a concentração de $4000 \mu \mathrm{g} \mathrm{mL}^{-1}$. A Figura 24 mostra os resultados obtidos para a emulsão QGOC(C) para a bactéria $P$. aeruginosa.

Escobedo-Lozano et al. (2015) avaliaram a atividade antimicrobiana da interação dos géis de quitosana/acemanan (polissacarídeo presente no Aloe vera). O gel de acemanan não mostrou atividade sobre a bactéria E. coli (ATCC 2028P) e também não evidenciou efeito sobre $S$. aureus (ATCC 6538P), dado este que difere dos resultados apresentados pelos óleos de copaíba para $S$. aureus neste estudo. $O$ 
gel de quitosana por sua vez, mostrou atividade apenas para $S$. aureus e com valor de CIM maior que a encontrada neste estudo (200 - $\left.100 \mu \mathrm{g} \mathrm{mL}{ }^{-1}\right)$. Os autores atribuem a diferença encontrada entre as bactérias às diferenças estruturais entre bactérias Gram-positivas e Gram-negativas, como mencionado no item 6.6, onde a genética da bactéria também é um fator determinante nas diferenças de sensibilidade encontradas nesse estudo e descritas na literatura. Contudo, a quitosana utilizada por Escobedo-Lozano et al. (2015), ainda, difere em relação a utilizada neste estudo na origem, sendo derivada de camarão, explicação plausível para a maior CIM descrita.

Figura 24 - llustração da combinação dos antimicrobianos da linhagem de $P$. aeruginosa, com as diferentes concentrações da emulsão QGOC(C).

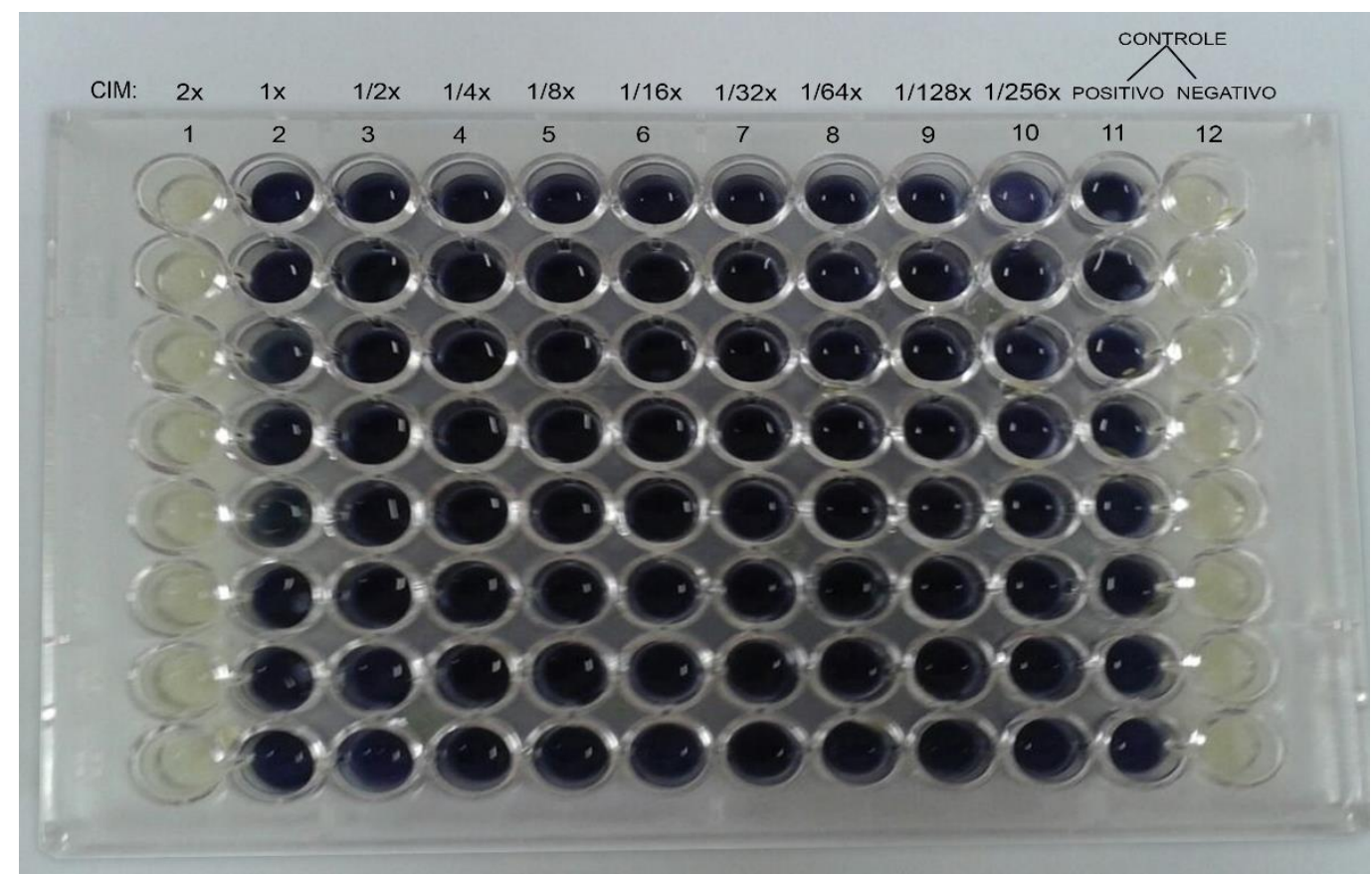

Fonte: Autoria própria.

Com a mistura dos géis de quitosana/acemanan em diferentes proporções, os autores observaram que a presença do acemanan influenciou a atividade bactericida da quitosana de maneira antagônica, fazendo com que os grupos amino protonados da quitosana perdessem a capacidade de interagir com a parede celular da bactéria S. aureus (ESCOBEDO-LOZANO et al., 2015).

Esses dados não corroboram com os obtidos para os óleos de copaíba, uma vez que, esse não interferiu de maneira negativa na inibição da linhagem de $S$. aureus, mas mostrou uma possível interação antagônica na inibição de $P$. aeruginosa, diminuindo o efeito do gel QG. Portanto, uma hipótese para as 
diferenças de sensibilidade observadas neste trabalho seria a diferença estrutural entre as bactérias como a camada lipídica, presença de proteínas, fimbrias, entre outras e a genética propriamente dita.

Segundo Yeh et al. (2010), estudos recentes já demonstram que interações antagonistas através de supressão, ou seja, quando a adição de um fármaco diminui o efeito que o outro fármaco isolado apresentava, pode ser mais vantajoso até mesmo que as interações sinérgicas, diminuindo e até revertendo o desenvolvimento de resistência bacteriana às moléculas antibióticas. O modelo experimental demonstrou que, quando dois fármacos são antagônicos ocorre uma competição entre as linhagens selvagens sensíveis e as mutantes resistentes, ampliando a faixa de concentrações em que a resistência ocorre e diminuindo a evolução bacteriana através de mutações espontâneas. Tal fato evidencia as vantagens do uso dos óleos de copaíba no gel QG, principalmente sobre a linhagem de $P$. aeruginosa, onde ocorreu a diminuição do efeito que o gel apresentava e sugere investigar sua importância clínica no panorama da multirresistência.

Sendo assim, é possível dizer que as emulsões obtidas podem ser exploradas para aplicação futura, uma vez que, a quitosana mostrou eficiente atividade antimicrobiana e os óleos de copaíba podem ser utilizados por seu notório efeito cicatrizante e até mesmo na investigação das interações sinérgicas e antagônicas com o gel de quitosana/gelatina, principalmente no contexto de infecções epidérmicas e na contenção do fenômeno da resistência bacteriana, sendo alvos de grande atratividade, principalmente por serem compostos de origem natural. Além disso, os dados aqui relatados não foram descritos na literatura até o presente momento, servindo de vertente para novos estudos na busca de medidas para minimizar a emergência de bactérias antibiótico-resistentes no ambiente hospitalar.

Todavia, é necessário que novos esforços sejam feitos na tentativa de prevenir, controlar e monitorar a resistência bacteriana de maneira global, com 0 desenvolvimento de novas moléculas sustentáveis. 


\subsection{Curva de sobrevivência}

O efeito do tempo sobre a atividade antimicrobiana foi evidenciado através de curvas de sobrevivência utilizando os antimicrobianos em combinação na forma de emulsões. Para isso, a emulsão $\mathrm{QGOC}(\mathrm{E})$ formulada a partir da mistura do óleo de copaíba escuro $\mathrm{OC}(\mathrm{E})$ e do gel $\mathrm{QG}$, foi escolhida para o teste, uma vez que, apresentou melhor perfil de sensibilidade. A bactéria utilizada também foi a que apresentou melhor resposta aos compostos, sendo esta $S$. aureus.

As curvas foram construídas utilizando-se a CIM encontrada para os antimicrobianos na forma de emulsão $\left(31,2 \mu \mathrm{g} \mathrm{mL} \mathrm{m}^{-1}\right.$ para $\mathrm{OC}(\mathrm{E})$ e $15,6 \mu \mathrm{g} \mathrm{mL}^{-1}$ para o gel QG), conforme descrito no item 6.10.

A curva de sobrevivência para $S$. aureus (Figura 25) demonstra que a emulsão QGOC(E) apresenta atividade a partir de 15 min de incubação, eliminando completamente a população bacteriana a partir de $2 \mathrm{~h}$ de tratamento. $\mathrm{O}$ efeito foi mantido durante as $24 \mathrm{~h}$ de tratamento, não indicando perfil de resistência e demonstrando o potencial da interação. Esses dados corroboram com os obtidos por Huang et al. (2011), que relatam que o tempo de tratamento da combinação acetato de quitosana e nanopartículas de prata foi de 30 min para eliminar a população bacteriana.

Figura 25 - Curva de sobrevivência de $S$. aureus: $(-)$ Controle positivo de crescimento e (-) QGOC(E) (mistura da CIM de 15,6 $\mu \mathrm{g} \mathrm{mL} \mathrm{L}^{-1}$ para QG e de $31,2 \mu \mathrm{g} \mathrm{mL}^{-1}$ para $\mathrm{OC}(\mathrm{E})$ ).

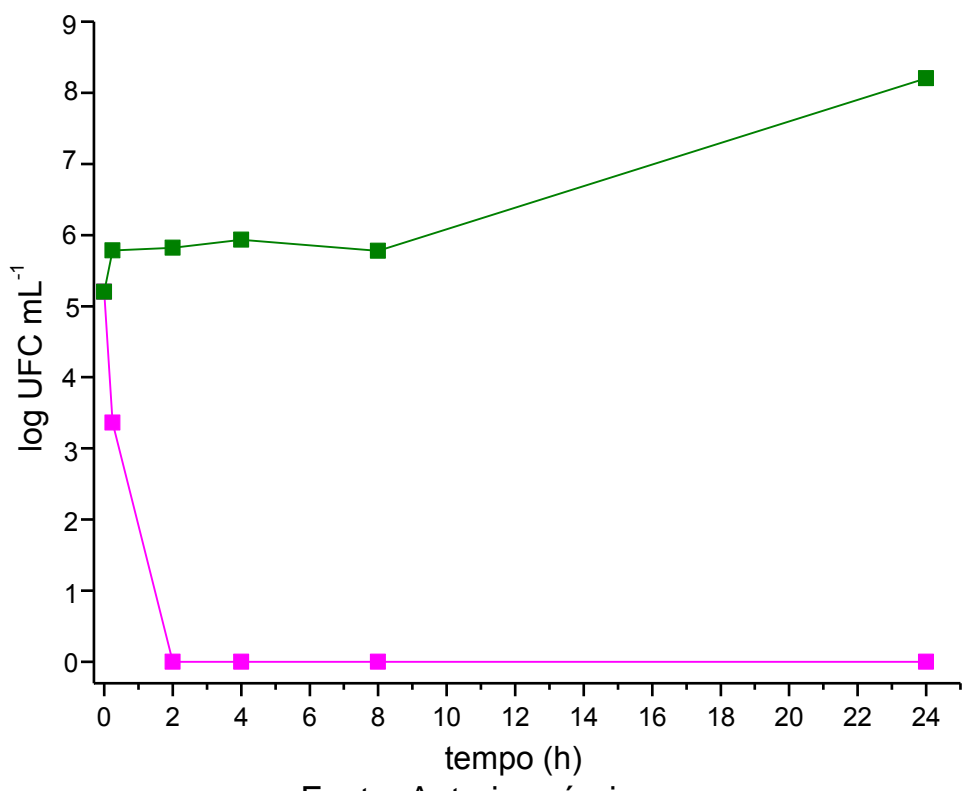

Fonte: Autoria própria. 
A curva de sobrevivência possibilitou evidenciar o comportamento cinético dos antimicrobianos em combinação na forma da emulsão QGOC(E), mostrando a efetividade da emulsão e sugerindo o seu possível uso como agente no controle de infecções bacterianas.

\subsection{Ensaio de citotoxicidade}

O ensaio de citotoxicidade in vitro foi utilizado como uma avaliação inicial do índice de sobrevivência das células após tratamento com os óleos de copaíba, o gel de quitosana/gelatina e emulsões em diferentes concentrações a fim de detectar um efeito citotóxico no sistema biológico. A viabilidade celular foi determinada utilizando o método do MTT, conforme item 5.14.4 (MOSMANN, 1983).

O índice de sobrevivência celular de cada amostra analisada para a linhagem VERO foi calculado conforme a equação 5 descrita no item 5.11 .13 a partir das medidas de absorbâncias lidas e pode ser visualizado na Figura 26 e Tabela 7.

Figura 26 - Viabilidade celular dos compostos Controle negativo, $\mathbb{O} \mathrm{OC}(\mathrm{S}), \mathbb{O} \mathrm{OC}(\mathrm{C})$, ஐ OC(E), 田 QG, QGOC(S), QGOC(C) e QGOC(E) em diferentes concentrações.

Sendo 1 = concentração inibitória mínima $(\mathrm{CIM}), 2=2 \mathrm{x}>\mathrm{CIM}$ e $4=4 \mathrm{x}>\mathrm{CIM}$.

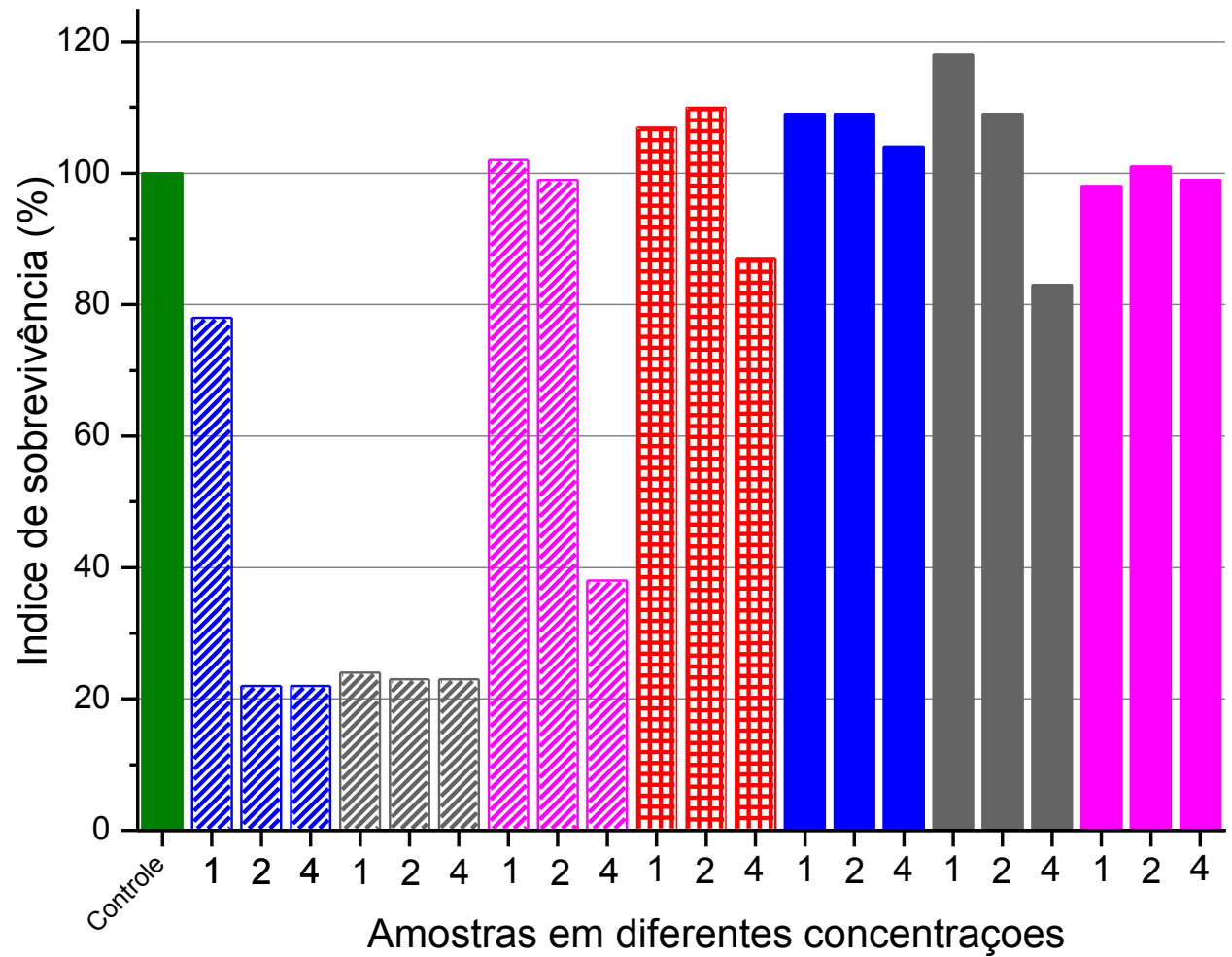


Resultados e Discussão

Tabela 7 - Índice de sobrevivência celular da linhagem VERO para cada amostra de óleo de copaíba, gel de quitosana/gelatina e emulsão em concentrações diferentes.

\begin{tabular}{|c|c|c|c|}
\hline Amostra & $\begin{array}{l}\text { Concentração } \\
\left(\mu \mathrm{gL}^{-1}\right)\end{array}$ & $\begin{array}{c}\text { Média das } \\
\text { Absorbâncias } \pm D P^{A}\end{array}$ & IS $^{B}(\%)$ \\
\hline \multirow[t]{2}{*}{ Controle } & - & $0,711 \pm 0,050$ & 100 \\
\hline & $4 \mathrm{x}>\mathrm{CIM}$ & $0,155 \pm 0,022$ & 22 \\
\hline \multirow[t]{3}{*}{ Óleo de copaíba OC(S) } & $2 x>C I M$ & $0,153 \pm 0,029$ & 22 \\
\hline & CIM & $0,544 \pm 0,281$ & 78 \\
\hline & $4 \mathrm{x}>\mathrm{CIM}$ & $0,165 \pm 0,033$ & 23 \\
\hline \multirow[t]{3}{*}{ Óleo de copaíba OC(C) } & $2 x>C I M$ & $0,164 \pm 0,035$ & 23 \\
\hline & CIM & $0,171 \pm 0,017$ & 24 \\
\hline & $4 \mathrm{x}>\mathrm{CIM}$ & $0,269 \pm 0,080$ & 38 \\
\hline \multirow[t]{2}{*}{ Óleo de copaíba OC(E) } & $2 x>C I M$ & $0,704 \pm 0,096$ & 99 \\
\hline & CIM & $0,724 \pm 0,067$ & 102 \\
\hline \multirow{4}{*}{$\begin{array}{c}\text { Gel de } \\
\text { quitosana/gelatina (QG) }\end{array}$} & $4 \mathrm{x}>\mathrm{CIM}$ & $0,620 \pm 0,120$ & 87 \\
\hline & $2 x>C I M$ & $0,785 \pm 0,108$ & 110 \\
\hline & CIM & $0,759 \pm 0,072$ & 107 \\
\hline & $4 \mathrm{x}>\mathrm{CIM}$ & $0,738 \pm 0,091$ & 104 \\
\hline \multirow[t]{3}{*}{ Emulsão QGOC(S) } & $2 \mathrm{x}>\mathrm{CIM}$ & $0,772 \pm 0,067$ & 109 \\
\hline & CIM & $0,772 \pm 0,044$ & 109 \\
\hline & $4 \mathrm{x}>\mathrm{CIM}$ & $0,588 \pm 0,072$ & 83 \\
\hline \multirow[t]{3}{*}{ Emulsão QGOC(C) } & $2 x>C I M$ & $0,774 \pm 0,036$ & 109 \\
\hline & CIM & $0,842 \pm 0,159$ & 118 \\
\hline & $4 \mathrm{x}>\mathrm{CIM}$ & $0,702 \pm 0,026$ & 99 \\
\hline \multirow[t]{2}{*}{ Emulsão QGOC(E) } & $2 x>C I M$ & $0,72 \pm 0,066$ & 101 \\
\hline & CIM & $0,696 \pm 0,064$ & 98 \\
\hline
\end{tabular}

${ }^{A}$ Desvio Padrão, ${ }^{B}$ Índice de Sobrevivência.

Fonte: Autoria própria.

Os resultados de índice de sobrevivência (IS) para os óleos de copaíba sobre a linhagem VERO mostraram que o óleo de copaíba adquirido em São Paulo $\mathrm{OC}(\mathrm{S})$ e o óleo de copaíba advindo de Belém com coloração clara $\mathrm{OC}(\mathrm{C})$ apresentaram alta citotoxicidade, de acordo com a classificação de Lönnroth (2005). Entretanto, o OC(S), na concentração correspondente a CIM, apresentou baixa citotoxicidade, com porcentagem de viabilidade celular de $78 \%$. Já, o óleo de 
copaíba escuro $\mathrm{OC}(\mathrm{E})$ nas concentrações de $2 \mathrm{x}>\mathrm{CIM}$ e $\mathrm{CIM}$, apresentou porcentagem de viabilidade celular superior a $90 \%$, não indicando citotoxicidade (LÖNNROTH, 2005).

Masson-Meyers et al. (2013) estudaram a citotoxicidade in vitro e as propriedades cicatrizantes do óleo resina de copaíba em feridas de coelhos e observaram que a concentração utilizada é diretamente proporcional ao efeito citotóxico do óleo. No caso do ensaio celular com fibroblastos 3T3 tratados com $100 \mathrm{mg} \mathrm{mL}^{-1}$ de óleo de copaíba não ocorreu citotoxicidade. Contudo, com o aumento da concentração de óleo para 500 e $1000 \mu \mathrm{g} \mathrm{m}^{-1}$, a porcentagem de viabilidade celular diminuiu indicando um perfil citotóxico. Neste estudo o mesmo efeito foi observado para o óleo de copaíba escuro $\mathrm{OC}(\mathrm{E})$ que não apresentou citotoxicidade devido à baixa concentração utilizada, já que sua concentração inibitória mínima foi menor em relação aos demais óleos.

O gel de quitosana gelatina (QG) e as emulsões QGOC(S), QGOC(C) e QGOC(E) não apresentaram citotoxicidade para VERO em todas as concentrações testadas, com porcentagem de viabilidade celular superior a $90 \%$ em todos os casos.

Campos, Mei e Santos Jr (2015) estudaram o efeito citotóxico de membranas de quitosana neutralizadas para serem utilizadas como substitutos de pele. Essas membranas quando em contato direto sobre células VERO resultaram um possível efeito citotóxico, diferentemente dos resultados encontrados para o gel de quitosana/gelatina deste estudo. Entretanto, quando as membranas foram utilizadas indiretamente sobre as células VERO para avaliar a liberação de substâncias tóxicas no meio de cultura, não foi observado citotoxicidade. Além disso, os autores também verificaram o aumento na porcentagem de viabilidade celular em relação ao controle negativo, o que pode ser atribuído a capacidade de estimular a proliferação celular da quitosana, fato este também observado neste estudo para o gel QG e para as emulsões.

Assim a utilização de emulsões formuladas a partir da mistura dos óleos de copaíba com os biopolímeros quitosana e gelatina, reduzindo efeitos secundários, ampliando a faixa de concentração e potencializando o efeito bactericida indica ser vantajosa para aplicações futuras em infecções de pele. 


\section{CONCLUSÕES}

Os óleos de copaíba de diferentes origens apresentam perfis de sensibilidade heterogêneo sobre Staphylococcus aureus, com predominante caráter bactericida. Destaca-se o potencial antimicrobiano apresentado pelo óleo de copaíba escuro.

O gel de quitosana/gelatina apresenta potencial antimicrobiano sobre as bactérias Staphylococcus aureus, Escherichia coli e Pseudomonas aeruginosa, com predominante ação bactericida, exceto em $P$. aeruginosa onde mostra comportamento bacteriostático.

A interação entre os antimicrobianos na forma da emulsão quitosana/gelatina/óleo de copaíba utilizando o óleo de copaíba escuro sugere efeito sinérgico sobre $S$. aureus, reduzindo a população de forma significativa após curto período de tempo.

As demais emulsões formuladas com os outros óleos de copaíba não caracterizam efeito sinérgico, mas a atividade antimicrobiana e o efeito bactericida foram mantidos com a adição dos óleos na mistura quitosana/gelatina, com exceção da bactéria $P$. aeruginosa em que a adição dos óleos reduziu a eficácia do gel de quitosana/gelatina.

Os óleos de copaíba de São Paulo e de Belém de coloração clara mostraram potencial citotóxico, enquanto o óleo de copaíba de Belém de coloração escura não apresentou citotoxicidade em duas concentrações diferentes. Já, o gel de quitosana/gelatina e todas as emulsões formuladas não apresentaram citotoxicidade em nenhuma das concentrações testadas, o que permite sua aplicação na clínica médica demonstrando as vantagens da combinação. 


\section{REFERÊNCIAS BIBLIOGRÁFICAS}

AGÊNCIA NACIONAL DE VIGILÂNCIA SANITÁRIA. Guia de estabilidade de produtos cosméticos. Brasília, 2004. Disponível

em:<http://www.anvisa.gov.br/divulga/public/series/cosmeticos.pdf >. Acesso em: 20 maio 2015.

ALVARENGA, E.S.; OLIVEIRA, C.P.; BELLATO, C.R. An approach to understanding the deacetylation degree of chitosan. Carbohydrate Polymers, v.80, p.1155-1160, 2010.

ANITHA, A. et al. Chitin and chitosan in selected biomedical applications. Progress in Polymer Science, v.39, n.9, p.1644-1667, Sept. 2014. Disponível em:<http://www.sciencedirect.com/science/article/pii/S0079670014000288>. Acesso em: 19 Mar. 2014.

BAKER, S. A Return to the pre-antimicrobial era?. Science, v.347, p.1064-1066, 2015. Doi:10.1126/science.aaa2828.

BONOMO, R.A.; SZABO, D. Mechanisms of multidrug resistance in Acinetobacter species and Pseudomonas aeruginosa. Clinical Infectious Diseases, v.43, p.4956, 2006.

BOZZA, M.; MUCIDA, D. Quem somos? Nós e trilhões de bactérias. Revista Carbono, 2013. Disponível em:<http://revistacarbono.com/artigos/02quem-somosnos-e-trilhoes-de-bacterias/>. Acesso em: 12 mar. 2015.

BRACONI, F.I. et al. Aplicação cosmética do óleo de canola. In: CONGRESSO LATINO AMERICANO E IBERRICO DE QUÍMICOS COSMÉTICOS, 12., 1995, São Paulo. Anais... São Paulo: Associação Brasileira de Cosmetologia, 1995. p.6-19.

CAMPANA-FILHO, S.P. et al. Extração, estruturas e propriedades de a e $\beta$-quitina. Química Nova, v.30, n.3, p.644-650, 2007.

CAMPOS, M.G.N.; MEI, L.H.I.; SANTOS JUNIOR, A.R. Sorbitol-plasticized and neutralized chitosan membranes as skin substitutes. Materials Research, v.18, n.4, p.781-790, 2015.

CENTERS FOR DISEASE CONTROL AND PREVENTION. Antibiotic / antimicrobial resistance, 2015. Disponível em:<http://www.cdc.gov/drugresistance/biggest threats.html>. Acesso em: 26 Aug. 2015.

. Healthcare-associated infections - diseases and organisms, 2011.

Disponível em:<http://www.cdc.gov/HAl/organisms/staph.html>. Acesso em: 6 Feb. 2014. 
CHANDUMPAI, A. et al. Preparation and physico-chemical characterization of chitin and chitosan from the pens of squid species, Loligo lessoniana and Loligo formosana. Carbohydrate Polymers, v.58, p.467-474, 2004.

CLINICAL AND LABORATORY STANDARDS INSTITUTE. M7-A6: Metodologia dos testes de sensibilidade a agentes antimicrobianos por diluição para bactéria de crescimento aeróbico: norma aprovada. 6.ed. Coordenação de tradução de Silvia Figueiredo costa. Brasília: Agência Nacional de Vigilância Sanitária, 2003. v.23, n.2.

DASH, M. et al. Chitosan - a versatile semi-synthetic polymer in biomedical applications. Progress in Polymer Science, v.36, p.981-1014, 2011.

DAVIES, J.; DAVIES, D. Origins and evolution of antibiotic resistance.

Microbiology and Molecular Biology Reviews, v.74, n.3, p.417-433, 2010.

DETHLEFSEN, L.; MCFALL-NGAI, M.; RELMAN, D.A. An Ecological and evolutionary perspective on human-microbe mutualism and disease. Nature, v.449, p.811-818, 2007.

DEUS, R.J.A.; ALVES, C.N.; ARRUDA, M.S.P. Avaliação do efeito antifúngico do óleo resina e do óleo essencial de copaíba (Copaifera multijuga Hayne). Revista Brasileira de Plantas Medicinais, v.13, p.1-7, 2011.

DIAS, D.O. et al. Optimization of copaíba oil-based nanoemulsions obtained by different preparation methods. Industrial Crops and Products, v.59, p.154-162, 2014.

DHILLON, G.S. et al. Recent development in applications of important biopolymer chitosan in biomedicine, pharmaceuticals and personal care products. Current Tissue Engineering, v.2, n.1, p.20-40, 2013.

ESCOBEDO-LOZANO, A.Y. et al. Physical properties and antibacterial activity of chitosan/acemannan mixed systems. Carbohydrate Polymers, v.115, p.707-714, 2015.

FARMER III, J.J.; BOATWRIGHT, K.D.; JANDA, M. Enterobacteriaceae: introduction and identification. In: MURRAY, P.R. et al. Manual of clinical microbiology. 9.ed. Washington: American Society for Microbiology, 2007. p.649-669.

FERRARI, M. Obtenção e aplicação de emulsões múltiplas contendo óleos de andiroba e copaíba. 1998. 147f. Dissertação (Mestrado) - Faculdade de Ciências Farmacêuticas de Ribeirão Preto, Universidade de São Paulo, Ribeirão Preto, 1998.

FERREIRA, L.L. Estrutura clonal e multirresistência em Pseudomonas aeruginosa. 2005. 99f. Dissertação (Mestrado em Vigilância Sanitária) - Instituto Nacional de Controle de Qualidade em Saúde, Fundação Oswaldo Cruz, Rio de Janeiro, 2005. 
FRESHNEY, R.I. Culture of animal cells: a manual of basic technique and specialized applications. $6^{\text {th }}$ ed. New York: Wiley BlackWell, 2010. v.1.

GAVHANE, Y.N.; GURAV, A.S.; YADAV, A.V. Chitosan and its applications: a review of literature. International Journal of Research in Pharmaceutical and Biomedical Sciences, v.4, n.1, p.312-331, 2013.

GOMES, N.M. et al. Antinociceptive activity of Amazonian copaiba oils. Journal of Ethnopharmacology, v.109, p.486-492, 2007.

Antineoplasic activity of Copaifera multijuga oil fractions against asciti and solid ehrlich tumor. Journal of Ethnopharmacology, v.119, p.179-184, 2008.

. Characterization of the antinociceptive and anti-inflammatory activities of fractions obtained from Copaifera multijuga Hayne. Journal of Ethnopharmacology, v.128, p.177-183, 2010.

GOMES, T.M.P. Conheça a pele. Disponível em:<http://drataniapimentel.site.med.br/index.asp?PageName=conheca-a-pele $>$. Acesso em: 24 abr. 2015.

GÓMEZ-ESTACA, J. et al. Biodegradable gelatin-chitosan films incorporated with essential oils as antimicrobial agents for fish preservation. Food Microbiology, v.27, p.889-896, 2010.

GÓMEZ-GUILLÉN, M.C. et al. Functional and bioactive properties of collagen and gelatin from alternative sources: a review. Food Hydrocolloids, v.25, p.1813-1827, 2011.

GOREN, A.C. et al. Essential oil composition of twenty-two Stachys species (mountain tea) and their biological activities. Phytochemistry Letters, v.4, p.448453, 2011.

GOY, R.C.; BRITTO, D.; ASSIS, O.B.G. A Review of the antimicrobial activity of chitosan. Polímeros: ciência e tecnologia, v.19, n.3, p.241-247, 2009.

GRICE, E.A.; SEGRE, J.A. The Skin microbiome. Nature Reviews, v.9, p.244-253, 2011.

HADWIGER, L.A. et al. Chitosan both activated genes in plants and inhibits RNA synthesis in fungi. In: MUZZARELLI, R.A.A.; JEUNIAUX, C.; GOODAY, G.W. (Ed.). Chitin in nature and technology. New York: Plenum, 1981.

HEALTHY PEOPLE. Healthcare-associated infections. 2013. Disponível em:<http://www.healthypeople.gov/2020/topicsobjectives2020/overview.aspx?topicld $=17>$. Acesso em: 6 Feb. 2014.

HELANDER, I.M. et al. Chitosan disrupts the barrier properties of the outer membrane of gram-negative bacteria. International Journal of Food Microbiology, v.71, p.235-244, 2001. 
HOLT, J.G. et al. Facultatively anaerobic gram-negative rods. In: HOLT, J.G. Bergey's manual of determinative bacteriology. $9^{\text {th }}$ ed. Baltimore: Lippincott Williams \& Wilkins, 1994.

HORN, M.M. Blendas e filmes de quitosana/amido de milho: estudo da influência da adição de polióis, oxidação do amido e razão amilose/amilopectina nas suas propriedades. 2012. 145f. Tese (Doutorado em Química Analítica e Inorgânica) Instituto de Química de São Carlos, Universidade de São Paulo, São Carlos, 2012.

HORN, M.M.; MARTINS, V.C.A.; PLEPIS, A.M.G. Interaction of anionic collagen with chitosan: effect on thermal and morphological characteristics. Carbohydrate Polymers, v.77, p.239-243, 2009.

HOWARD, S.J.; HOPWOOD, S.; DAVIES, S.C. Antimicrobial resistance: a global challenge. Science, v.6, p.1-2, 2014.

HUANG, L. et al. Synergistic combination of chitosan acetate with nanoparticle silver as a topical antimicrobial: efficacy against bacterial burn infections. Antimicrobial Agents and Chemotherapy, v.55, n.7, p.3432-3438, 2011.

IDSON, B. Stability testing of emulsions. Drug and Cosmetic Industry, v.142, n.1, p.27-28, 1993.

INDEX KEWENSIS. Supplement XX. Oxford: Claredon, 1996.

ISLAM, MD.M. et al. Antibacterial activity of crab-chitosan against Staphylococcus aureus and Escherichia coli. Journal of Advanced Scientific Research, v.2, n.4, p.63-66, 2011.

JEON, S.J. et al. Underlying mechanism of antimicrobial activity of chitosan microparticles and implications for the treatment of infectious diseases. Plos One, v.9, n.3, 2014. Doi:10.1371/journal.pone.0092723.

JUMAA, M.; FURKERT, F.H.; MÜLLER, B.W. A New lipid emulsion formulation with high antimicrobial efficacy using chitosan. European Journal of Pharmaceutics and Biopharmaceutics, v.53, p.115-123, 2002.

KAKKAR, P. et al. Development of keratin-chitosan-gelatin composite scaffold for soft tissue engineering. Materials Science and Engineering, v.45, p.343-347, 2014.

KONG, M. et al. Antimicrobial properties of chitosan and mode of action: a state of the art review. International Journal of Food Microbiology, v.144, p.51-63, 2010.

KUBO, I.; MUROI, H.; HIMEJIMA, M. Antimicrobial activity of green tea flavor components and their combination effects. Journal of Agricultural and Food Chemistry, v.40, n.2, p.245-248, 1992. 
KUETE, V. et al. Antibacterial activity of some natural products against bacteria expressing a multidrug-resistant phenotype. International Journal of Antimicrobial Agents, v.37, p.156-161, 2011.

Antimicrobial activity of the methanolic extract, fractions and compounds from the stem bark of Irvingia gabonensis (Ixonanthaceae). Journal of Ethnopharmacology, v.114, p.54-60, 2007.

KUMIRSKA, J. et al. Application of spectroscopic methods for structural analysis of chitin and chitosan. Marine Drugs, v.8, p.1567-1636, 2010.

KURITA, K. et al. Squid chitin as a potencial alternative chitin source: deacetylation behavior and characteristic properties. Journal of Polymer Science: part A polymer chemistry, v.31, p.485-491, 1993.

LEANDRO, L.M. et al. Chemistry and biological activities of terpenoids from copaiba (Copaifera spp.) oleoresins. Molecules, v.17, n.4, p.3866-3889, 2012.

LIMA, S.R. et al. In vivo and in vitro studies on the anticancer activity of Copaifera multijuga hayne and its fractions. Phytotherapy Research, v.17, p.1048-1053, 2003.

LING, L.L. et al. A New antibiotic kills pathogens without detectable resistance. Nature, 2015. Doi:10.1038/nature14098.

LIU, D. et al. Determination of the degree of acetylation of chitosan by UV spectrophotometry using dual standards. Carbohydrate Research, v.341, p.782785, 2006.

LÖNNROTH, E.C. Toxicity of medical glove materials: a pilot study. International Journal of Occupational Safety and Ergonomics (JOSE), v.11, n.2, p.131-139, 2005.

LUCCA, L.G. Avaliação da permeação cutânea de nanoemulsão contendo óleo de copaíba incorporada em hidrogéis. 2013. 73f. Dissertação (Mestrado em Ciências Farmacêuticas) - Faculdade de Farmácia, Universidade Federal do Rio Grande do Sul, Porto Alegre, 2013.

MASSON, D.S. et al. Atividade antimicrobiana do óleo-resina de copaíba (Copaifera langsdorffii) em bactérias de significância clínica em úlceras cutâneas. Revista

Brasileira de Plantas Medicinais, v.15, n.4, supl.I, p.664-669, 2013.

MASSON-MEYERS, D.S. et al. Cytotoxicity and wound healing properties of Copaifera langsdorffii oleoresin in rabbits. Internacional Journal of Natural Product Science, v.3, n.3, p.10-20, 2013.

MCCHESNEYA, J.D.; CLARK, A.M.; SILVEIRA, E.R. Antimicrobial diterpenes of Croton sonderzanus, 1-hardwickic and 4,4-secotrachylobanoic acids. Journal of Natural Products, v.54, p.1635-1633, 1991. 
MELLEGARD, $\mathrm{H}$. et al. Antibacterial activity of chemically defined chitosans: influence of molecular weight, degree of acetylation and test organism. International Journal of Food Microbiology, v.148, p.48-54, 2011.

MENDONÇA, D.E.; ONOFRE, S.B. Atividade antimicrobiana do óleo-resina produzido pela copaíba - Copaifera multijuga Hayne (Leguminosae). Revista Brasileira de Farmacognosia, v.19, n.2, p.577-581, 2009.

MOSMANN, T. Rapid colorimetric assay for cellular growth and survival: application to proliferation and citotoxicity assays. Journal of Immunological Methods, v.65, p.55-63, 1983.

NOGUEIRA, E.O. et al. Avaliação do efeito do óleo-resina de copaíba (Copaifera sp.) na proliferação celular in vitro. Brazilian Journal of Veterinary Research and Animal Science, v.49, n.4, p.293-300, 2012.

PACHECO, T.A.R.C.; BARATA, L.E.S.; DUARTE, M.C.T. Antimicrobial activity of copaiba (Copaifera spp) balsams. Revista Brasileira de Plantas Medicinais, v.8, p.123-124, 2006.

PACKER, J.F.; LUZ, M.M.S. Método para avaliação e pesquisa da atividade antimicrobiana de produtos de origem animal. Revista Brasileira de

Farmacognosia, v.17, n.1, p.102-107, 2007.

PATERSON, D.L. The Epidemiological profile of infections with multidrug-resistant Pseudomonas aeruginosa and Acinetobacter species. Clinical Infectious Diseases, v.43, p.43-48, 2006.

PEIX, A.; RAMÍREZ-BAHENA, M.H.; VELÁSQUEZ, E. Historical evolution and current status of the taxonomy of genus Pseudomonas. Infection, Genetics and Evolution, v.9, p.1132-1147, 2009.

PEREDA, M. et al. Chitosan-gelatin composites and bi-layer films with potential antimicrobial activity. Food Hydrocolloids, v.25, p.1372-1381, 2011.

PÉREZ-LÓPEZ, A. et al. Activity against Streptococcus pneumoniae of essential oil and $\delta$-cadinene isolated from Schinus molle fruit. Journal of Essential Oil Research, v.23, p.25-28, 2011.

PIERI, F.A.; MUSSI, M.C.; MOREIRA, M.A.S. Óleo de copaíba (Copaifera sp.): histórico, extração, aplicações industriais e propriedades medicinais. Revista Brasileira de Plantas Medicinais, v.11, n.4, p.465-472, 2009.

PIERI, F.A. et al. Antimicrobial activity of autoclaved and non autoclaved copaiba oil on Listeria monocytogenes. Ciência Rural, v.40, n.8, p.1797-1801, 2010a.

Efeitos clínicos e microbiológicos do óleo de copaíba (Copaifera officinalis) sobre bactérias formadoras de placa dental em cães. Arquivo Brasileiro de Medicina Veterinária e Zootecnia, v.62, n.3, p.578-585, 2010b. 
PIERI, F.A. et al. Inhibition of Escherichia coli from mastitic milk by copaiba oil. Semina: ciências agrárias, v.32, p.1929-1934, 2011.

Antimicrobial profile screening of two oils of Copaifera genus. Arquivo

Brasileiro de Medicina Veterinária e Zootecnia, v.64, n.1, p.241-244, 2012.

RABEA, E.I. et al. Chitosan as antimicrobial agent: applications and mode of action. Biomacromolecules, v.4, n.6, p.1457-1465, 2003.

RIEGER, M.M. Teste de estabilidade para macroemulsões. Cosmetic \& Toiletries, v.8, n.5, p.47-53, 1996.

RINAUDO, M. Chitin and chitosan: properties and applications. Progress in Polymer Science, v.31, p.603-632, 2006.

ROLLER, S.; COVILL, N. The Antifungal properties of chitosan in laboratory media and apple juice. International Journal of Food Microbiology, v.47, p.67-77, 1999.

SAJOMSANG, W. et al. Synthesis of methylated chitosan containing aromatic moieties: chemoselectivity and effect on molecular weight. Carbohydrate Polymers, v.72, p.740-750, 2008.

Quaternization of $\mathrm{N}$-aryl chitosan derivatives: synthesis, characterization, and antibacterial activity. Carbohydrate Research, v.344, p.2502-2511, 2009.

SANTOS, A.O. et al. Antimicrobial activity of Brazilian copaiba oils obtained from different species of the Copaifera genus. Memórias do Instituto Oswaldo Cruz, v.103, n.3, p.277-281, 2008.

SANTOS, F.M.S. Utilização de quitosana no revestimento de filés de tilápia do Nilo (Oreochromis niloticus) e na preparação de filmes incorporados com óleos essenciais. 2014. 147f. Tese (Doutorado em Bioquímica e Fisiologia) Universidade Federal de Pernambuco, Recife, 2014.

SANTOS, J.E. et al. Caracterização de quitosanas comerciais de diferentes origens. Polímeros: ciência e tecnologia, v.13, n. 4, p.242-249, 2003.

SEBTI, I. et al. Chitosan polymer as bioactive coating and film against Apergillus niger contamination. Journal of Food Science, v.70, n.2, p.M100-M104, 2005.

SOUZA, A.B. et al. Antimicrobial evaluation of diterpenes from Copaifera langsdorffi oleoresin against periodontal anaerobic bacteria. Molecules, v.16, n.11, p.96119619, 2011.

SUDARSHAN, N.R.; HOOVER, D.G.; KNORR, D. Antibacterial action of chitosan. Food Biotechnology, v.6, n.3, p.257-272, 1992.

SYDNOR, E.R.M.; PERL, T.M. Hospital epidemiology and infection control in acutecare settings. Clinical Microbiology Reviews, v.24, n.1, p.141-173, 2011. 
TAN, H. et al. Quaternized chitosan as an antimicrobial agent: antimicrobial activity, mechanism of action and biomedical applications in orthopedics. International Journal of Molecular Sciences, v.14, p.1854-1869, 2013.

TINCUSI, B.M. et al. Antimicrobial terpenoids from the oleoresin of the peruvian medicinal plant Copaifera paupera. Planta Médica, v.68, p.808-812, 2002.

TORRES, M.A. et al. Produção e caracterização de microesferas de quitosana modificadas quimicamente. Polímeros: ciência e tecnologia, v.15, n.4, p.306-312, 2005.

TORTORA, G.J.; FUNKE, B.R.; CASE, C.L. Microbiologia. Porto Alegre: Artmed, 2012.

VEIGA JUNIOR, V.F.; PINTO, A.C. O gênero Copaifera L. Química Nova, v.25, n.2, p.273-286, 2002.

VEIGA JUNIOR, V.F. et al. Chemical composition and anti-inflammatory activity of copaiba oils from Copaifera cearensis Huber ex Ducke, Copaifera reticulate Ducke and Copaifera multijuga Hayne - a comparative study. Journal of

Ethnopharmacology, v.112, n.2, p.248-254, 2007.

VERMA, P. Methods for determining bactericidal activity and antimicrobial interactions: synergy testing, time-kill curves, and population analysis. In: SCHWALBE, R.; STEELE-MOORE, L.; GOODWIN, A.C. Antimicrobial susceptibility testing protocols. Boca Raton: Taylor \& Francis, 2007. p.275-299.

WANG, X. et al. Chitosan-metal complexes as antimicrobial agent: synthesis, characterization and structure-activity study. Polymer Bulletin, v.55, p.105-113, 2005.

WITT, M.A. et al. Crosslinked chitosan/poly(vinyl alcohol) blends with proton conductivity characteristic. Journal of Brasilian Chemistry Society, v.21, n.9, p.1692-1698, 2010.

YEH, P.J. et al. Drug interactions and the evolution of antibiotic resistance. Nature Reviews Microbiology, v.7, n.6, p.460-466, 2010.

YOUNES, I. et al. Influence of acetylation degree and molecular weight of homogeneous chitosans on antibacterial and antifungal activities. International Journal of Food Microbiology, v.185, p.57-63, 2014. 